Felipe Augusto Souza Gualberto

\title{
Valor diagnóstico da nested PCR em tempo real em pacientes com meningite
}

\section{tuberculosa}

Tese apresentada à Faculdade de Medicina da Universidade de São Paulo para obtenção do título de Doutor em Ciências

Programa de Doenças Infecciosas e Parasitárias Orientador: Dr. José Ernesto Vidal Bermúdez

São Paulo 
Dados Internacionais de Catalogação na Publicação (CIP)

Preparada pela Biblioteca da

Faculdade de Medicina da Universidade de São Paulo

Creprodução autorizada pelo autor

Gualberto, Felipe Augusto Souza

Valor diagnóstico da nested PCR em tempo real em pacientes com meningite tuberbulosa / Felipe Augusto Souza Gualberto. -- São Paulo, 2014.

Tese(doutorado)--Faculdade de Medicina da Universidade de São Paulo.

Programa de Doenças Infecciosas e Parasitárias.

Orientador: José Ernesto Vidal Bermúdez.

Descritores: 1.Tuberculose meníngea/diagnóstico 2.Mycobacterium tuberculosis 3.DNA 4.Reação em cadeia da polimerase em tempo real/métodos 5.Técnicas de amplificação de ácido nucleico 6.Líquido cefalorraquidiano

7.Sensibilidade e especificidade 8.Grupos diagnósticos relacionados/classificação

USP/FM/DBD-091/14 
Felipe Augusto Souza Gualberto

\section{Valor diagnóstico da nested PCR em tempo real em pacientes com meningite}

\section{tuberculosa}

Tese apresentada à Faculdade de Medicina da Universidade de São Paulo para obtenção do título de Doutor em Ciências

Programa de Doenças Infecciosas e Parasitárias Orientador: Dr. José Ernesto Vidal Bermúdez

São Paulo 


\section{DedicatóRia}

À Deus
que primeiro sorriu: quanto nos divertimos juntos!
A minha mãe Del e ao meu pai Dé,
que sorrindo me ensinaram a sorrir.

Aos meus irmãos, Fred e Let, lado a lado os sorrisos são intermináveis.

À minha família:

que bom é sorrir em Casa!

Aos meus pacientes:

em meio ao sofrimento, que privilégio é sorrir com vocês.

Aos funcionários do Emílio, do CRT e todos meus amigos: os dias nunca são iguais pois sempre estamos sorrindo... 


\section{AGRADECIMENTOS}

Agradeço a Deus, que colocou em meio caminho pessoas tão amáveis e prestativas, imagem da sua bondade e beleza. Agradeço àqueles que, por minha falta de atenção, foram esquecidos ou não mencionados. Agradeço a minha família, grande Família!, pelo carinho de sempre.

Agradeço ao grande amigo e orientador Dr. José Vidal que em meio a um mar de informações guiou-me pelos caminhos da melhor formação.

Agradeço ao Cláudio Sacchi, que abriu as portas para este projeto. Obrigado ao Dr. Augusto Penalva pelo repetido apoio e incentivo.

Agradeço de modo especial a Gisele e Lucila, responsáveis pelas reações em cadeia da polimerase. Obrigado pela disponibilidade de sempre e pelos tantos momentos de valioso aprendizado.

Ainda no Adolfo Lutz, instituto que alberga pessoas tão preciosas, agradeço à Maristela, Terezinha, Ana Vera e todos dos demais laboratórios com os quais tive contato, especialmente Suely e Cristina da Virologia.

Agradeço ao Prof. Dr. Aluísio Segurado e todos os professores da FMUSP com quem tanto aprendi nas aulas e estágios. Obrigado Suely, pelo apoio na biblioteca. Agradeço a todos da Secretaria da Pós-graduação e de modo especial à Roseli: muito obrigado por toda atenção e disponibilidade!

Obrigado a todos da Divisão Científica do Emílio Ribas, de modo especial a Dra. Anna Cristina e a Almerinda. Agradeço aos médicos(as), enfermeiros(as), técnicos(as) e auxiliares de enfermagem do Emílio e do CRT DST-Aids, que com tanto desvelo cuidaram dos pacientes que fazem parte dessa tese. Obrigado aos pacientes que tanto contribuíram para minha formação médica e humana: cada dia aprendendo mais com vocês!

Agradeço a todos os amigos médicos e residentes que avisaram dos pacientes com suspeita de meningite tuberculosa: Audrey, Juliana Gerhardt, 
Juliana Maria, Giselle, Débora, Paula, Vítor, Daniel Licy, Bartman, Brunno, Júlia, Daniella, Danila, Michele, Ângela e Aline, Igor Thiago, Cinthia, Aline, Dani Orlandis, Tati, André, Ana Cláudia, Paulo, Juliana Salles, Marcelo, Thiago, Flávia Sacco, Eder Gatti, João Paulo (in memorian), Marina, Cláudia, Renata, Filipe Perini, Marcelo, Roberto Muniz, Fabrício, Tiago, Fernando, Sara, Lídia, Lucy, Bruna, Marcela, Maysa, Magali, Lilian, Vanessa, Marina e Aline. Obrigado Dr. Marcelo pela revisão do texto.

Obrigado a todos que trabalham no laboratório do Emílio Ribas e do CRT. Obrigado pela paciência quando tanto importunei: Solange, Luciano, Daine, Alecsandra, Alessandra, Márcia Tereza, Irma, Tânia, Eva, Suzana, Célia, Elisabete, Sérgio Luiz, Regina, Luciano, Dra. Meire, Aparecida, Marlene. Ao pessoal da microbiologia Wilma Augusta, Maria Inês, Vilma, Rita de Cássia, Silvia, Marta, Érica de Lima, Maria Beatriz. Ao pessoal da Hematologia: Francisca, Edna, Lúcia, Rosana, Juliana, Marjorie. A todos da sorologia e bioquímica, Hatsuko, Maria de Lourdes, Silvia Vieira, Marilde, Simone Neves, Tatiana Erika, Luzia, Salete, Fátima, Ana Paula, Cristian. Àqueles que trabalham com CD4 e CV: Eliza, Maridéia, Dalva, Oscar, Vilanilse, Fátima Takako, Jane, Francis. Àqueles que trabalham com líquor: Gil, Izabel, Fabiana e Solange. À Ilda, Geralda e Gledenaide. E aos responsáveis pelos laboratórios: Vera Marlene, Izabel, Wilma Assunção, Locrécia, Dercival, Andréia Regina, Simone Aparecida, Simone Alcântara, Luiza Dias, Karen, Francisco Erinaldo, Dr. Manoel, Dr. Carlos Senne, Dr. Renato Ramos, Dr. Beno, Dr. Terezinha, Dra. Ana Lúcia e Dra. Meire. Obrigado todos funcionários do SAME: invejo vossa paciência!

Ao Dr. Lee Harrison que colaborou para minha formação profissional em discussões tão enriquecedoras e apoiando estágios no exterior. Obrigado pelas sugestões tão importantes para o trabalho.

E agradeço a todos os professores do colégio e da universidade que, ainda que não tenham colaborado diretamente para esta tese, apontaram o caminho que conduziu até aqui. De modo especial, a Prof. Dra. Ângela Maria Ribeiro com quem trabalhei os três primeiros anos da faculdade: a iniciação científica foi muito mais que um início, foi o sólido fundamento! 
"O necessário para se conseguir a felicidade não é uma vida cômoda, mas sim um coração apaixonado."

(São Josemaria Escrivá) 


\section{NORMALIZAÇÃo UTILIZADA}

Esta tese está de acordo com as seguintes normas, em vigor no momento desta publicação:

Referências: adaptado de International Committee of Medical Journals Editors (Vancouver).

Universidade de São Paulo. Faculdade de Medicina. Divisão de Biblioteca e Documentação. Guia de apresentação de dissertações, teses e monografias. Elaborado por Anneliese Carneiro da Cunha, Maria Julia de A. L. Freddi, Maria F. Crestana, Marinalva de Souza Aragão, Suely Campos Cardoso, Valéria Vilhena. 3a ed. São Paulo: Divisão de Biblioteca e Documentação; 2011.

Abreviaturas dos títulos dos periódicos de acordo com List of Journals Indexed in Index Medicus. 


\section{SUMÁRIO}

Lista de Figuras

Lista de Gráficos

Lista de Tabelas

Lista de Siglas

Resumo

Summary

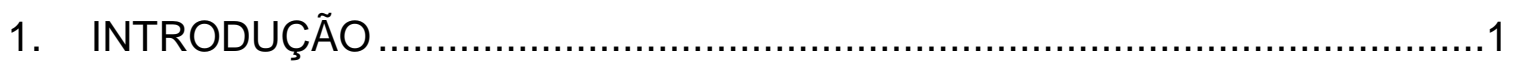

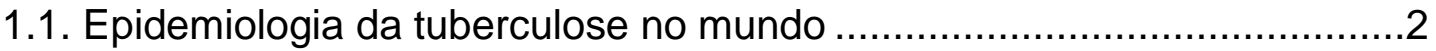

1.2. Epidemiologia da tuberculose no Brasil .........................................

1.3. Tuberculose no Estado de São Paulo..................................................5

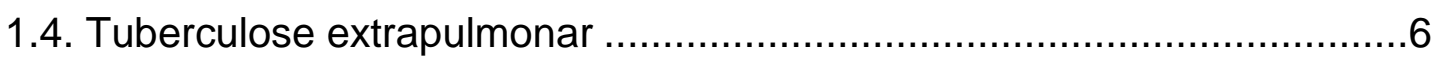

1.5. Tuberculose do sistema nervoso central......................................... 8

1.6. Fisiopatologia e aspectos clínicos da tuberculose do sistema nervoso

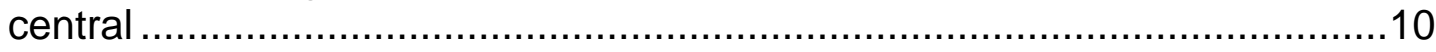

1.7. Avaliação da gravidade e prognóstico da meningite tuberculosa...........13

1.8. Tuberculose do sistema nervoso central em pacientes com HIV ...........14

1.9. Diagnóstico da meningite tuberculosa...........................................16

1.10. Aspectos radiológicos no diagnóstico da meningite tuberculosa .........17

1.11. Dificuldades no diagnóstico confirmatório da meningite tuberculosa ...18

1.12. Diagnóstico da meningite tuberculosa em pacientes infectados por

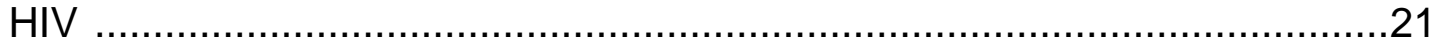

1.13. Critérios e categorias diagnósticas de meningite tuberculosa..............23

1.14. Biologia molecular no diagnóstico de meningite tuberculosa ...............24

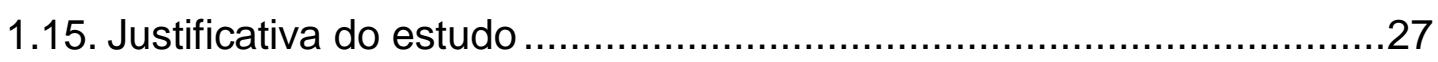

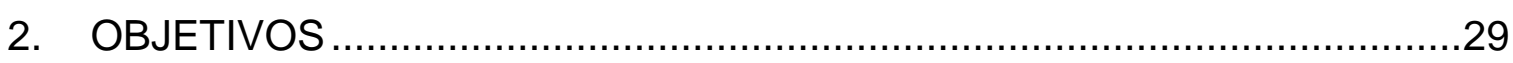

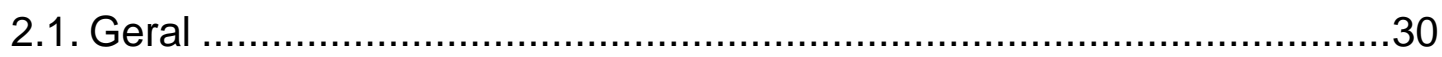

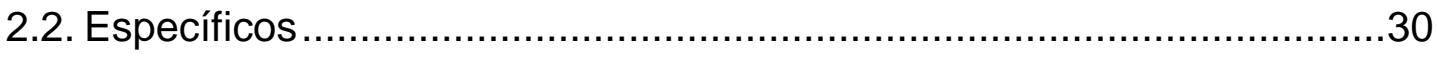

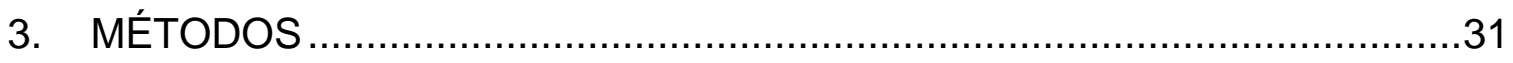

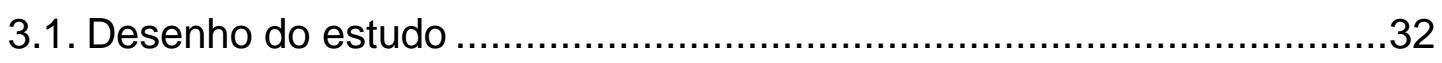

3.2. Fluxo de recrutamento dos casos e critérios de inclusão ......................33

3.3. Categorias diagnósticas dos pacientes com suspeita de MTB ..............34

3.4. Fluxo laboratorial e análise do líquor............................................41

3.5. Reações em cadeia da polimerase .................................................42

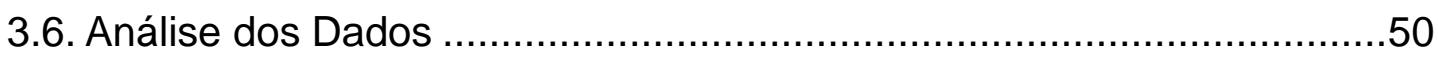

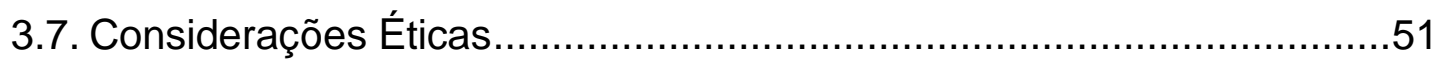

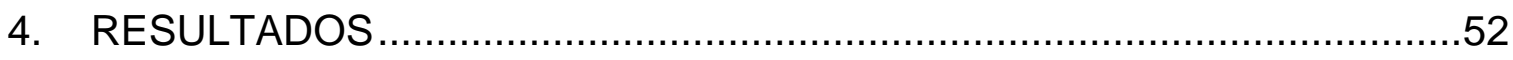




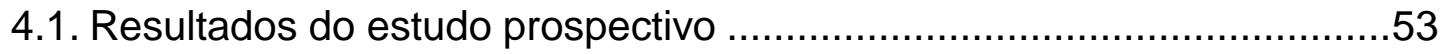

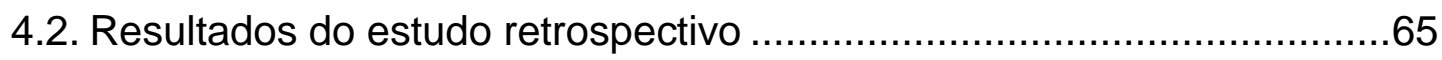

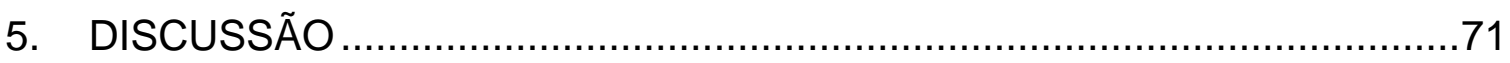

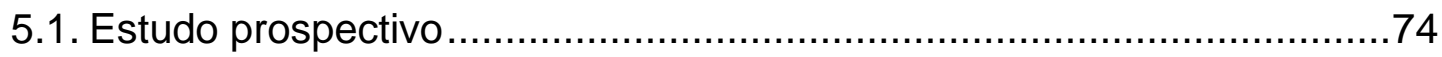

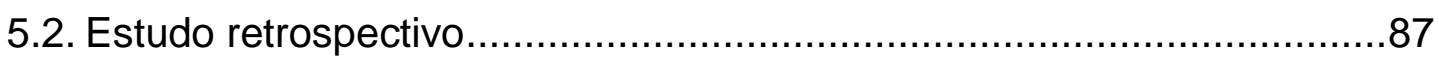

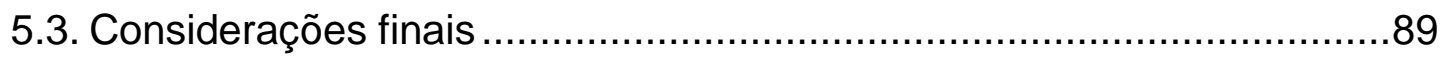

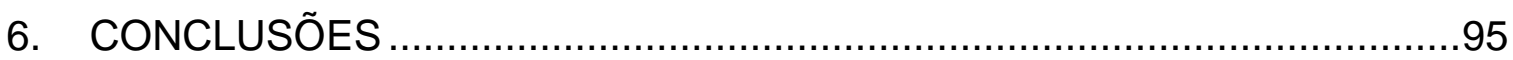

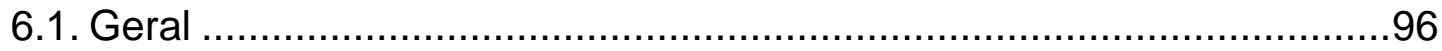

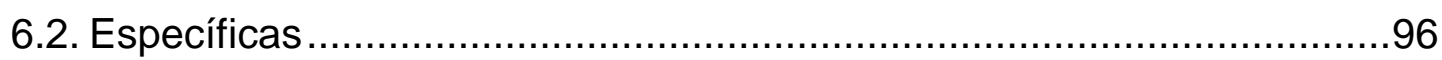

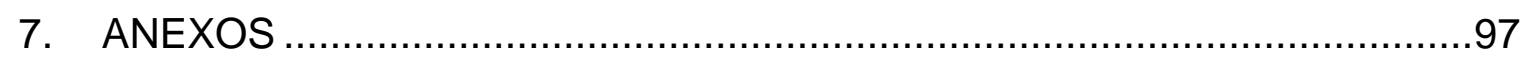

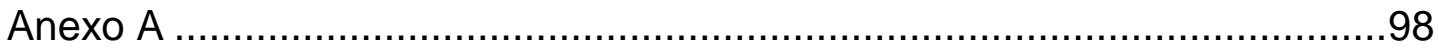

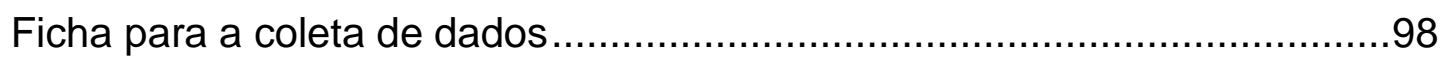

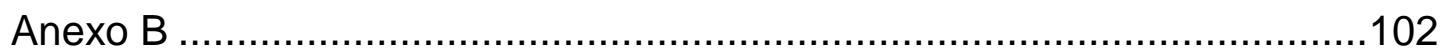

Termos de Consentimento Livre e Esclarecido.........................................102

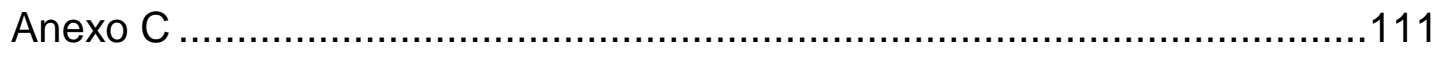

Aprovações dos Comitês de Ética em Pesquisa........................................111

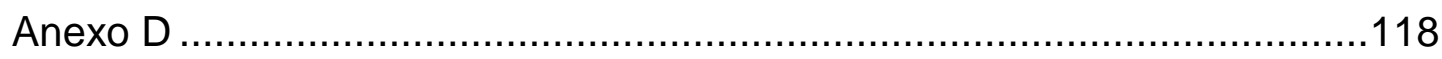

Formulário de solicitação do exame de nRT-PCR no LCR .......................118

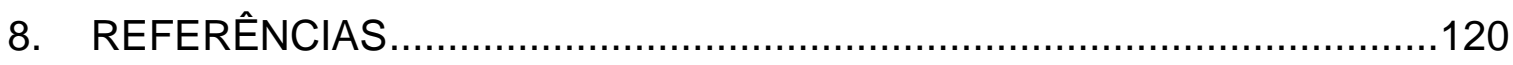




\section{LISTA DE FIGURAS}

Figura 1 - Categorias diagnósticas dos pacientes incluídos propostas a partir da revisão da literatura 38

Figura 2 - Fluxograma do estudo com classificação inicial e final dos pacientes conforme as categorias diagnósticas padronizadas 57

Figura 3 - Exemplo representativo do resultado da reação da nRT-PCR

Figura 4 - Classificação inicial e final dos pacientes conforme as categorias diagnósticas padronizadas. 67

\section{LISTA DE GRÁFICOS}

Gráfico 1 - Incidência de tuberculose por 100 mil habitantes no Brasil entre

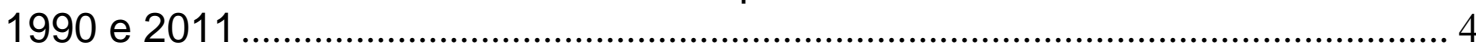

Gráfico 2 - Porcentagem de casos de tuberculose com teste para HIV realizado e porcentagem de positivos no Município de São Paulo ......................... 6

Gráfico 3- Distribuição de tuberculose segundo a apresentação clínica no Brasil

Gráfico 4 - Box Plot mostrando a diferença de pontuação final entre as categorias diagnósticas padronizadas dos pacientes 58 


\section{LISTA DE TABELAS}

Tabela 1 - Casos novos de meningite tuberculosa na capital e em todo o estado de São Paulo entre 2006 e 2012 (número total e entre pacientes HIV positivos)

Tabela 2 - Estudos neuropatológicos de pacientes com aids em países em desenvolvimento

Tabela 3 - Achados clínicos, radiológicos e laboratoriais de pacientes infectados e não infectados pelo HIV com meningite tuberculosa

Tabela 4 - Critérios e escore para a classificação dos pacientes nas categorias diagnósticas internacionais padronizadas de MTB

Tabela 5 - Fragmentos do gene mpt64 do M. tuberculosis (GeneBank BX842578) e os locais de ligação dos iniciadores (primers) e da sonda (probe) utilizados

Tabela 6 - Tabela para cálculo de sensibilidade e especificidade do teste quando comparados ao padrão-ouro

Tabela 7 - Características principais dos pacientes conforme categoria diagnóstica padronizada de MTB

Tabela 8 - Características principais dos pacientes infectados por HIV conforme categoria diagnóstica padronizada de MTB

Tabela 9 - Classificação dos pacientes nas categorias diagnósticas propostas

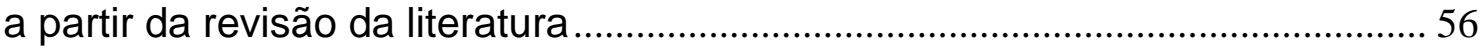

Tabela 10 - Diagnósticos dos pacientes incluídos na categoria "Não MTB" ..... 61

Tabela 11 - Micro-organismos isolados em hemoculturas dos pacientes

Tabela 12 - Distribuição dos pacientes nas categorias diagnósticas propostas a partir da revisão da literatura e resultado da nRT-PCR, com dados de sensibilidade, especificidade e intervalos de confiança [IC95\%]

Tabela 13 - Distribuição dos pacientes nas categorias diagnósticas padronizadas e resultado da nRT-PCR, com dados de sensibilidade, especificidade e intervalos de confiança [IC95\%]

Tabela 14 - Distribuição dos pacientes HIV positivos nas categorias diagnósticas padronizadas e resultado da nRT-PCR, com dados de sensibilidade, especificidade e intervalos de confiança [IC95\%]

Tabela 15 - Classificação dos pacientes do estudo retrospectivo nas categorias diagnósticas propostas a partir da revisão da literatura . 
Tabela 16 - Diagnósticos dos pacientes incluídos na categoria "Não MTB" no estudo retrospectivo

Tabela 17 - Distribuição dos pacientes nas categorias diagnósticas padronizadas e resultado da nRT-PCR na fase retrospectiva, com dados de sensibilidade, especificidade e intervalos de confiança [IC95\%] ......................... 70

Tabela 18 - Distribuição dos pacientes HIV positivos nas categorias diagnósticas padronizadas e resultado da nRT-PCR, com dados de sensibilidade, especificidade e intervalos de confiança [IC95\%]......................... 70 


\section{LISTA DE SIGLAS}

$\begin{array}{ll}\text { BAAR } & \text { Bacilo álcool-ácido resisteste } \\ \text { BK } & \text { Bacilo de Koch } \\ \text { CMV } & \text { Citomegalovírus } \\ \text { CRT DST/AIDS } & \text { Centro de Referência e Treinamento em DST e Aids } \\ \text { Ct } & \text { Cycle threshold } \\ \text { CVE } & \text { Centro de Vigilância Epidemiológica } \\ \text { IAL } & \text { Instituto Adolfo Lutz } \\ \text { IIER } & \text { Instituto de Infectologia Emílio Ribas } \\ \text { LCR } & \text { Líquido cefalorraquidiano } \\ \text { LEMP } & \text { Leucoencefalopatia multifocal progressiva } \\ \text { MAC } & \text { Mycobacterium avium complex } \\ \text { MTB } & \text { Meningite tuberculosa } \\ \text { n-PCR } & \text { Reação em cadeia da polimerase no formato nested } \\ \text { nRT-PCR } & \text { Reação em cadeia da polimerase em tempo real no formato nested } \\ \text { OMS } & \text { Organização Mundial de Saúde } \\ \text { PCNT } & \text { Programa Nacional de Controle de Tuberculose } \\ \text { PCR } & \text { Reação em cadeia da polimerase } \\ \text { RM de crânio } & \text { Ressonância magnética de crânio } \\ \text { RT-PCR } & \text { Reação em cadeia da polimerase em tempo real } \\ \text { SNC } & \text { Sistema Nervoso Central } \\ \text { TB } & \text { Tuberculose } \\ \text { TC de crânio } & \text { Tomografia de crânio }\end{array}$


Gualberto FAS. Valor diagnóstico da nested PCR em tempo real em pacientes com meningite tuberculosa [Tese]. São Paulo: Faculdade de Medicina, Universidade de São Paulo; 2014.

Introdução: A meningite tuberculosa (MTB) é a forma mais grave e fatal de tuberculose. O diagnóstico oportuno e o tratamento adequado e precoce são os principais fatores associados com o bom prognóstico. Os métodos utilizados na prática médica diária - achados clínicos, exames de imagem e análise de líquido cefalorraquidiano ( $\mathrm{LCR}$ ) - têm baixa acurácia. A pesquisa do DNA do Mycobacterium tuberculosis no LCR através da reação em cadeia da polimerase (PCR, do inglês polimerase chain reaction) com a metodologia nested é promissora, especialmente quando associada à praticidade da amplificação do DNA em tempo real. Objetivo: Avaliar o valor diagnóstico da nested PCR em tempo real (nRT-PCR, do inglês nested real-time PCR) na investigação de pacientes com MTB. Métodos: Estudo observacional realizado em duas fases: uma prospectiva e outra retrospectiva. Na fase prospectiva, foram incluídos pacientes com suspeita de MTB internados no Instituto de Infectologia Emílio Ribas (IIER). Informações clínicas, laboratoriais e radiológicas foram coletadas, assim como amostra de LCR de todos os pacientes. A partir de critérios internacionais padronizados, os pacientes foram categorizados como "MTB Definitiva", "MTB Provável", "MTB Possível" e "Não MTB". A nRT-PCR, utilizando o gene alvo mpt64, foi realizada em todas as amostras de LCR no Laboratório de Meningites Bacterianas do Instituto Adolfo Lutz. Sensibilidade, especificidade e intervalos de confiança (IC 95\%) da nRTPCR foram calculados com base no padrão-ouro (cultura positiva para $M$. tuberculosis ou isolamento de BAAR no sistema nervoso central) e nos pacientes com outros diagnósticos estabelecidos (Não MTB). Também foi calculada a proporção de pacientes com a nRT-PCR positiva em cada categoria clínica. Na fase retrospectiva, foi realizada uma revisão de prontuários de pacientes que tiveram a nRT-PCR solicitada no IIER e no Centro de Referência e Treinamento em DST/AIDS. Os mesmos procedimentos de categorização diagnóstica, cálculos de sensibilidade e especificidade foram adotados. Resultados: $\mathrm{Na}$ fase prospectiva, foram 
incluídos 102 pacientes, sendo 92 deles infectados por HIV. Nove deles tiveram o padrão-ouro positivo e foram classificados como "MTB Definitiva" e 81 deles tiveram outros diagnósticos estabelecidos ("Não MTB"). A sensibilidade e a especificidade da nRT-PCR foi 100\% (IC95\%:70-100 e 95-100, respectivamente). A positividade da nRT-PCR na categoria "MTB Provável" foi $50 \%$ (4/8 pacientes) e $25 \%$ na "MTB Possível" (1/4). Na fase retrospectiva, 56 pacientes foram incluídos, sendo 48 infectados por HIV. A nRT-PCR teve sensibilidade de $83 \%$ (5/6) e especificidade de $100 \%$ (0/45). A positividade na categoria "MTB Provável" foi $60 \%(3 / 5)$ e não houve pacientes classificados como "MTB Possível". Conclusão: A nRT-PCR apresentou boa sensibilidade e ótima especificidade, demonstrando seu valor diagnóstico na identificação oportuna de casos de MTB.

Descritores: Tuberculose meníngea/diagnóstico; Mycobacterium tuberculosis; DNA; Reação em cadeia da polimerase em tempo real/métodos; Técnicas de amplificação de ácido nucleico; Líquido cefalorraquidiano; Sensibilidade e especificidade; Grupos diagnósticos relacionados/classificação. 
Gualberto FAS. Diagnostic value of the nested real time PCR in patients with tuberculous meningitis [Thesis]. São Paulo: Faculdade de Medicina, Universidade de São Paulo; 2014.

Background: Tuberculous meningitis (TBM) is the most serious and lethal presentation of tuberculosis. Timely diagnosis and appropriated treatment are the main factors associated with good outcome. Methods used in the daily medical practice - clinical, radiological and cerebrospinal fluid (CSF) findings have low accuracy. Search for Mycobacterium tuberculosis DNA in the CSF by polymerase chain reaction (PCR) using the nested methodology is promising, especially when combined with the practical approach of the real time DNA amplification. Objective: To evaluate the diagnostic value of a nested real-time PCR (nRT-PCR) in the investigation of patients with TBM. Methods: A twophase observational study was carried out: prospective and retrospective. In the prospective phase, patients with suspected TBM hospitalized at "Instituto de Infectologia Emílio Ribas" (IIER) were included. Clinical, laboratory and radiological data were collected, as well as CSF samples of all patients. According to international standard criteria, patients were categorized as "TBM Definite", "TBM Probable", "TBM Possible" and "Not TBM". The nRT-PCR, using the mpt64 gene, was performed on all CSF sample in the Laboratory of Bacterial Meningitis, Adolfo Lutz Institute. Sensitivity, specificity and confidence intervals $(95 \% \mathrm{Cl})$ of the nRT-PCR were calculated based on the gold standard (culture positive for $M$. tuberculosis or AFB isolation on the central nervous system) and on patients with other established diagnoses ("Not TBM"). The proportion of patients with a positive nRT-PCR in each clinical category was also calculated. In the retrospective phase, medical chart review was performed in those patients who had the nRT-PCR requested in IIER and in the "Centro de Referência e Treinamento em DST/AIDS". The same diagnostic categorization and calculations of sensitivity and specificity were adopted. Results: 102 patients were included in the prospective phase, 92 of them HIV-infected. Nine of them had the gold standard positive and were classified as "TBM Definite" and 81 of them had other diagnoses established ("Not TBM"). The sensitivity and specificity of the nRT-PCR were $100 \%(95 \% \mathrm{Cl}: 70-100$ and $95-100$, 
respectively). The nRT-PCR positivity in category "TBM Probable" was 50\% (4/8 patients) and $25 \%$ in "TBM Possible" (1/4). In retrospective phase, the nRTPCR had a sensitivity of $83 \%(5 / 6)$ and specificity of $100 \%$ (0/45), among the 56 included patients (48 of them HIV infected). Positivity in "TBM Probable" category was $60 \%(3 / 5)$ and no patients were classified as "TBM Possible". Conclusion: The nRT-PCR showed good sensitivity and excellent specificity, showing its diagnostic value in the timely identification of TBM.

Descriptors: Tuberculous, meningeal/diagnosis; Mycobacterium tuberculosis; DNA; Real-time polymerase chain reaction/methods; Nucleic acid amplification techniques; Cerebrospinal fluid; Sensitivity and specificity; Diagnosis-related groups/classification. 
1. INTRODUÇÃO 
Estima-se que um terço da população mundial esteja infectado pelo Mycobacterium tuberculosis (Lonnroth et al., 2008, WHO, 2013). Ocorreram 8,6 milhões de novos casos de tuberculose (TB) ativa e 1,3 milhões de mortes em 2012 (WHO, 2013). Entre as mortes causadas por um único agente infeccioso, a TB ocupa o segundo lugar, depois do vírus da imunodeficiência humana (HIV) (WHO, 2013).

Entre as formas extrapulmonares de TB, a meningite tuberculosa (MTB) é a forma mais grave e letal. Ela ocorre principalmente quando as atividades de prevenção, diagnóstico e tratamento dos casos pulmonares não ocorrem oportuna e adequadamente, de modo especial entre pacientes imunodeprimidos (WHO, 2013). Ao redor de 30\% dos casos de MTB resultam em óbito (Donald et al., 2005) e essa taxa pode atingir 70\% em países em desenvolvimento (Marx et al., 2011). Cerca de 50\% dos pacientes desenvolve sequelas (Marx et al., 2011), incluindo diminuição da capacidade intelectual, doenças psiquiátricas, convulsões recorrentes, assim como déficits visuais, motores e auditivos (Donald et al., 2005).

Devido a essa morbimortalidade acentuada, a MTB constitui um importante problema de saúde pública, com impactos econômicos e sociais significativos, especialmente na população infectada por HIV (Marais et al., 2010a). O diagnóstico oportuno associado à instituição imediata do tratamento são os principais fatores associados ao bom prognóstico e à prevenção de sequelas neurológicas (Shankar et al., 1991; Kox et al., 1995; Scarpellini et al., 1995; Ho et al., 2013; Thwaites et al., 2013).

\subsection{Epidemiologia da tuberculose no mundo}

Aproximadamente $95 \%$ dos novos casos de TB ocorrem em países em desenvolvimento, que também são os responsáveis por $98 \%$ das mortes causadas pela TB. Há predomínio da infecção nos indivíduos entre 15 - 54 anos, provocando enormes prejuízos socioeconômicos, por afetar especialmente a parcela da população economicamente ativa (WHO, 2013). 
Pobreza, migrações populacionais, resistência medicamentosa e a infecção por HIV são os maiores responsáveis pela manutenção da epidemia de TB (Corbett et al., 2006). O risco de adquirir TB também é maior entre aqueles que apresentam outras condições que prejudicam o sistema imunológico: pacientes desnutridos, tabagistas, etilistas e portadores de diabetes (WHO, 2013).

A TB e o HIV formam uma combinação potencialmente letal, que contribui para disseminação de ambas as infecções. O risco de adquirir a infecção é 21 a 34 vezes maior nos pacientes infectados por HIV quando comparados a indivíduos soronegativos (Antonucci et al., 1995; WHO, 2013). A TB também é a infecção mais comum entre as pessoas vivendo com HIV, incluindo aquelas em terapia antiretroviral. Em 2012, aproximadamente 13\% (1 milhão) dos novos casos eram coinfectados por HIV. Além disso, a TB ainda é a principal causa de morte entre esses pacientes, sendo responsabilizada em $25 \%$ dos casos. Ocorreram 320.000 mortes decorrentes da associação entre TB e HIV em 2012 (WHO, 2013).

Progressos importantes na redução do impacto da TB foram conquistados nas últimas décadas, após um esforço global por conter a doença. Cerca de 22 milhões de vidas foram salvas desde 1995 através estratégias de prevenção, diagnóstico precoce e tratamento supervisionado. A taxa de mortalidade também caiu $45 \%$ desde 1990 . Outro avanço recente foi o aumento do número de testes para HIV entre os pacientes diagnosticados com TB, que subiu para $46 \%$ em todo mundo. No entanto, apesar das quedas na incidência e mortalidade, a TB ainda é um grande desafio de saúde pública, tanto por sua abrangência global quanto pelo aumento das cepas de $M$. tuberculosis resistentes (WHO, 2013).

\subsection{Epidemiologia da tuberculose no Brasil}

O Brasil ocupa a $17^{a}$ posição, entre o grupo dos 22 países em desenvolvimento que contribuem com $82 \%$ da ocorrência dos novos casos no mundo (Brasil, 2013; WHO, 2013). As estimativas apontam para cerca de 50 
milhões de infectados pelo bacilo de Koch (BK) no Brasil (Brasil, 2013). Segundo dados da Organização Mundial de Saúde (OMS), o número notificações de casos novos no Brasil em 2012 foi de 71.230 mil, com 40.152 mil casos bacilíferos (WHO, 2013).

A sorologia para HIV foi realizada em 53\% dos pacientes diagnosticados com TB no Brasil em 2012. A taxa de incidência estimada em pacientes HIV positivos foi de 8/100.000 habitantes (WHO, 2013) e a coinfecção ocorreu em 10\% dos casos notificados (Brasil, 2013).

Observa-se um declínio lento, mas progressivo na incidência de TB no Brasil em todas as regiões entre 2001 e 2011 (Gráfico 1). A OMS divulgou que o Brasil já alcançou a meta de reduzir pela metade a taxa de mortalidade por TB quando comparada às taxas de 1990 (WHO, 2013). No entanto, a TB ainda é uma doença com alta taxa de mortalidade, com cerca de 5 mil óbitos por ano e 2,4 mortes por 100.000 habitantes (Brasil, 2013). A despeito de ser uma doença cujo tratamento oferece $97 \%$ de eficácia, ocupa a $4^{\underline{a}}$ posição no número de mortes entre as doenças infecciosas no Brasil, sendo a primeira causa de óbito entre pacientes com HIV (Brasil, 2013).

\section{Gráfico 1 - Incidência de tuberculose por 100 mil habitantes no Brasil entre 1990 e 2011}

Por 100.000 hab.
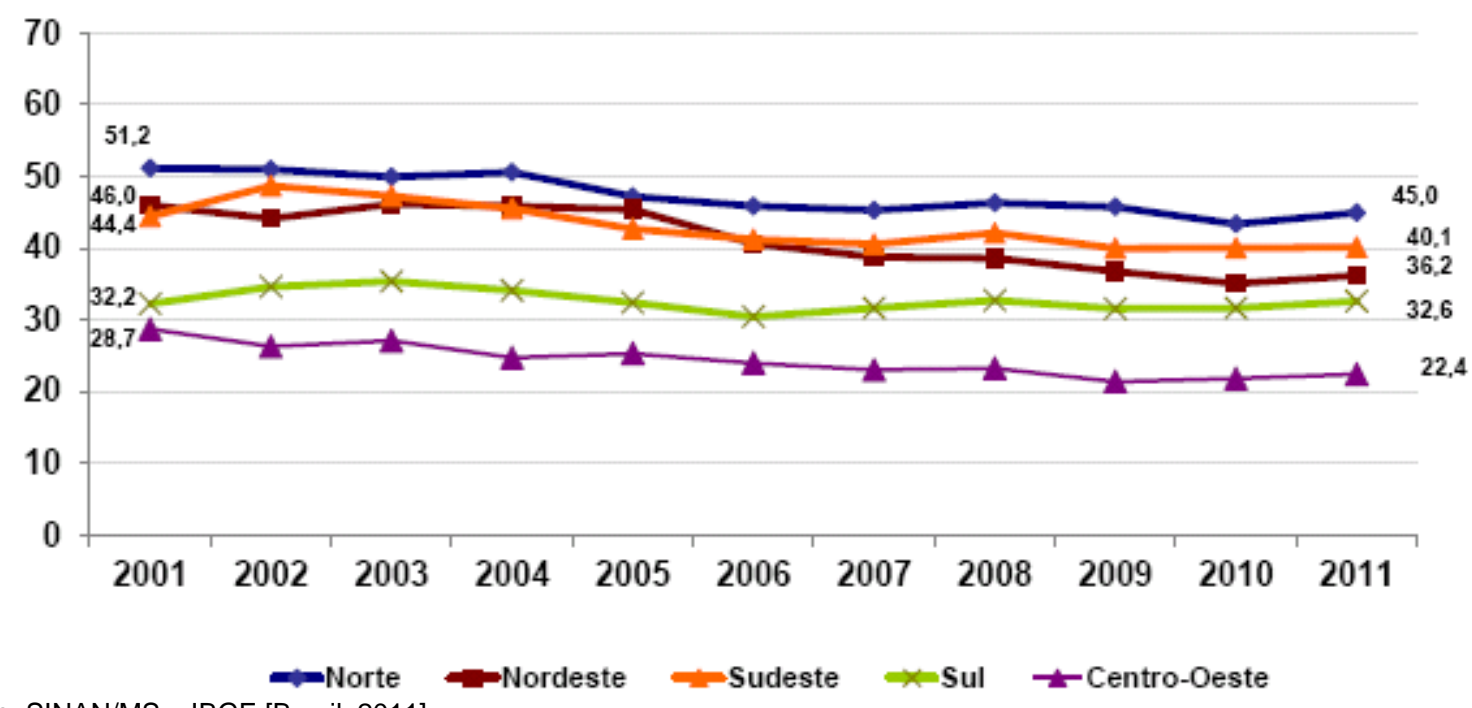


\subsection{Tuberculose no Estado de São Paulo}

São Paulo é o estado brasileiro que apresenta o maior contingente de casos de TB, com cerca de $20 \%$ do total de casos notificados no Brasil. A taxa de incidência no estado se assemelha àquela observada no país, com 38 casos por 100.000 habitantes em 2012. A taxa de mortalidade em 2011 foi de 2,1 mortes por 100.000 habitantes (CVE/SP, 2013).

Na cidade de São Paulo, no ano de 2012, foram notificados 5.473 novos casos de tuberculose, o que corresponde a uma taxa de incidência de 48 casos por 100 mil habitantes (CVE/SP, 2013). Essa taxa ultrapassa a observada no Estado de São Paulo e no Brasil, tornando-se a TB um grande desafio de saúde pública para o município.

Atualmente, a proporção de cura entre os casos pulmonares bacilíferos no Estado de São Paulo é de $80 \%$, 2 melhor índice entre os estados brasileiros (Brasil, 2013). Uma meta para garantir o melhor controle da TB no Estado de São Paulo é conseguir atingir a cura de pelo menos $85 \%$ dos casos diagnosticados. $\mathrm{O}$ tratamento diretamente observado, que vem crescendo em todo estado entre 2001 e 2012 - chegando a $58 \%$ dos casos na capital -, tem contribuído para atingir essa meta (CVE/SP, 2013).

Outro dado epidemiológico relevante na cidade de São Paulo diz respeito à testagem dos pacientes com TB para HIV. Entre 2001 e 2012, observou-se um aumento de 64 para $81 \%$ entre pacientes com TB testados para HIV (Gráfico 2). Entre casos novos de TB em 2012, o HIV foi diagnosticado $11 \%$ deles (CVE/SP, 2013). 


\section{Gráfico 2 - Porcentagem de casos de tuberculose com teste para HIV realizado e porcentagem de positivos no Município de São Paulo}

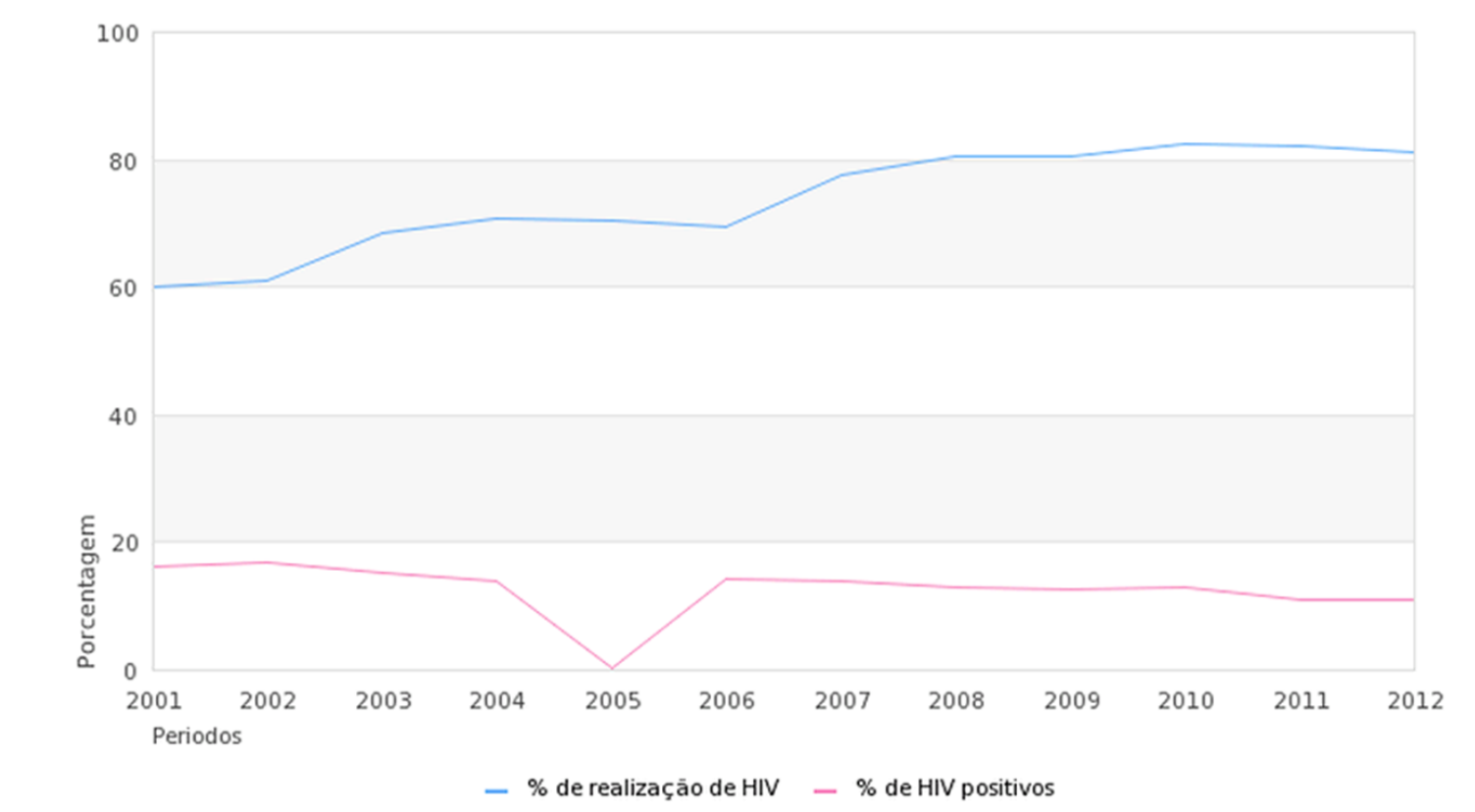

Fonte: CVE/SP (2013). Divisão de Controle da Tuberculose. Sala de Situação de Tuberculose do estado de SP.

\subsection{Tuberculose extrapulmonar}

Após a inalação dos bacilos álcool-ácido resistentes (BAAR) causadores da TB, alguns desfechos clínicos podem ocorrer: (I) clearance do micro-organismo; (ii) infecção latente; (iii) doença primária pulmonar; (iv) reativação vários anos após a infecção primária (Fitzgerald; Haas, 2005). Cerca de $5-10 \%$ dos pacientes que entram em contato com M. tuberculosis desenvolverão doença ativa ao longo de suas vidas (Comstock, 1982), mas essa probabilidade aumenta entre pacientes imunodeprimidos, especialmente aqueles com a síndrome da imunodeficiência humana (aids) (CDC, 1992).

Nos casos de TB primária - mais comumente - ou na reativação, se os mecanismos imunológicos para o controle do bacilo não forem eficazes, pode ocorrer envolvimento de órgãos extrapulmonares (Fitzgerald; Haas, 2005). Geralmente 0 bacilo se dissemina por contiguidade e pela via linfohematogênica. Entre os órgãos/sistemas mais afetados, estão a pleura, os linfonodos, os ossos, o sistema gênito-urinário e o sistema nervoso central 
(SNC) (Fanning et al., 1999; Peto et al., 2009; García-Rodriguez et al., 2011; Sandgren et al., 2013).

De acordo com a OMS, o diagnóstico de TB extrapulmonar é baseado na cultura positiva para $M$. tuberculosis ou evidência histológica/clínica consistente com doença extrapulmonar ativa, seguida pela decisão clínica de tratar a TB com agentes específicos. Os casos em que o paciente se apresenta com doença pulmonar e acometimento extrapulmonar são classificados como casos de TB pulmonar (WHO, 2013).

Nas publicações médicas que contemplam temas de saúde pública, nota-se que a TB extrapulmonar é menos estudada que a TB pulmonar. Ainda que haja uma vasta literatura sobre os casos de TB extrapulmonar, ela ainda é vista mais como uma peculiaridade clínica do que como um problema de saúde pública. Recebe, portanto, menos atenção das medidas internacionais de controle da TB (Peto et al., 2009; Yone et al., 2013). Uma das justificativas desse fato está relacionada à baixa contribuição dos casos de TB extrapulmonar na transmissão da TB, diferentemente dos casos pulmonares (Yone et al., 2013). Outro motivo é a maior dificuldade diagnóstica (Sandgren et al., 2013). No entanto, esses casos contribuem de modo significativo para a morbimortalidade associada com a TB (Leeds et al., 2012). Apesar da diminuição global na incidência de TB, os casos extrapulmonares estão se mantendo estáveis ou aumentando proporcionalmente nos últimos anos (Peto et al., 2009; García-Rodriguez et al., 2011; Leeds et al., 2012; WHO, 2013).

Em 2012, entre os 6,1 milhões de casos notificados de TB no mundo, 800.000 eram formas extrapulmonares (WHO, 2013). Desses casos, 11.356 ocorreram no Brasil (14\% dos casos novos de TB), sendo 2.848 no Estado de São Paulo (SINAN, 2013). O Gráfico 3 ilustra a distribuição de TB segundo a apresentação clínica no Brasil. 
Gráfico 3- Distribuição de tuberculose segundo a apresentação clínica no Brasil

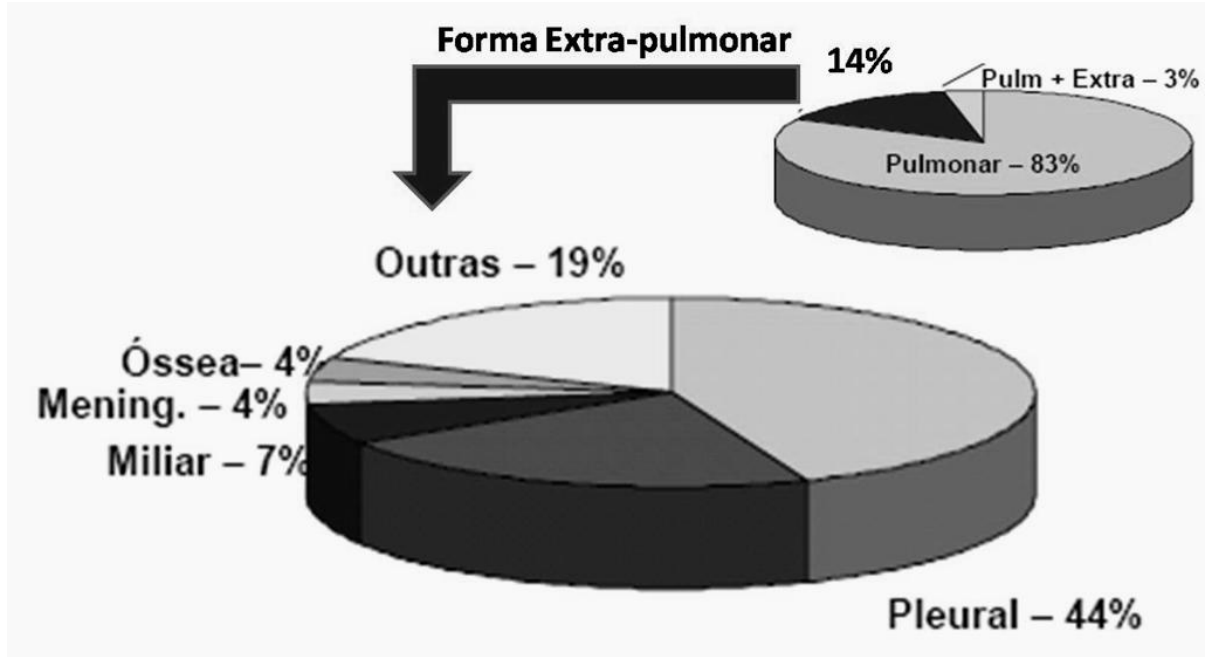

Gangl. Perif. - 22\%

Fonte: Adaptado de Brasil, SVS/MS (2011).

A infecção por HIV é um dos fatores de risco mais comunmente associados com a TB extrapulmonar, especialmente os casos mais graves como a meningite (Leeds et al., 2012). Entre pacientes com aids, 0 envolvimento extrapulmonar pode ser observado em até $50 \%$ daqueles com o diagnóstico de TB pulmonar (Golden et al., 2005; Sandgren et al., 2013; Yone et al., 2013). O risco da infecção extrapulmonar e da doença disseminada aumenta com o avanço da imunossupressão nesses pacientes (Golden et al., 2005; Leeds et al., 2012).

\subsection{Tuberculose do sistema nervoso central}

Entre as apresentações extrapulmonares, a TB do SNC é a mais grave. Possui três formas de apresentação: ( $I$ ) meníngea: meningoencefalite e meningite tuberculosa - forma de apresentação mais comum; (ii) encefálicas focais: tuberculomas e abscessos; (iii) mielorradiculares: mielite, mieloradiculite, tuberculomas e abscessos medulares. Adicionalmente, formas mistas podem ser observadas como a meningomieloradiculite (Donald et al., 2005). Nesta tese, as formas meníngeas serão abordadas de forma agrupada, como meningite tuberculosa (MTB). 
O maior estudo epidemiológico prospectivo avaliando a TB do SNC foi realizado no Canadá (Phypers et al., 2006): observou-se que ela corresponde a $1 \%$ dos casos totais de TB. No que diz respeito apenas à MTB, estudos epidemiológicos mais recentes evidenciaram que ela correspondia a $3 \%$ dos casos entre os pacientes com TB extrapulmonar na Alemanha (Ducomble el al., 2013), 4,1\% no norte da Espanha (Gárcia-Rodriguez et al., 2011) e 5,4\% nos Estados Unidos (Peto et al., 2009). Um estudo conduzido no Vietnam entre 2007 e 2010 em treze hospitais apontou uma prevalência de 6\% em pacientes adultos com suspeita de infecção do SNC (Ho et al., 2012). Infelizmente não há outros estudos epidemiológicos abrangentes sobre MTB em países em desenvolvimento (Garg; Sinha, 2011)

Segundo os últimos dados disponíveis do Ministério da Saúde (SINAN, 2013), no ano de 2012, ocorreram 652 casos notificados de MTB no Brasil (5,7\% dos casos de TB extrapulmonar), sendo 261 deles no Estado de São Paulo. O percentual de pacientes com HIV entre esses casos foi de 53\%, tanto para o Brasil quanto para São Paulo. Devido à baixa sensibilidade dos métodos diagnósticos e às limitações dos sistemas de notificação, estima-se que o número de casos de MTB seja maior (CVE, 2013).

Na Tabela 1, observa-se que o número de casos de MTB sofreu pouca variação em São Paulo (capital e estado) ao longo dos últimos sete anos. 
Tabela 1 - Casos novos de meningite tuberculosa na capital e em todo o estado de São Paulo entre 2006 e 2012 (número total e entre pacientes HIV positivos)

\begin{tabular}{lcccc}
\hline & \multicolumn{2}{c}{ CAPITAL } & ESTADO SP \\
\hline ANO & HIV + & Total & HIV + & Total \\
$\mathbf{2 0 0 6}$ & $80(61 \%)$ & 132 & $151(59 \%)$ & 258 \\
$\mathbf{2 0 0 7}$ & $81(59 \%)$ & 137 & $157(55 \%)$ & 288 \\
$\mathbf{2 0 0 8}$ & $63(56 \%)$ & 113 & $133(54 \%)$ & 246 \\
$\mathbf{2 0 0 9}$ & $68(52 \%)$ & 130 & $160(55 \%)$ & 292 \\
$\mathbf{2 0 1 0}$ & $57(56 \%)$ & 102 & $129(55 \%)$ & 236 \\
$\mathbf{2 0 1 1}$ & $56(49 \%)$ & 114 & $141(54 \%)$ & 261 \\
$\mathbf{2 0 1 2}$ & $54(50 \%)$ & 108 & $120(48 \%)$ & 249 \\
\hline
\end{tabular}

Fonte: CVE/SP (2013). Divisão de Controle da Tuberculose. Sala de Situação de Tuberculose do estado de SP.

\subsection{Fisiopatologia e aspectos clínicos da tuberculose do sistema nervoso central}

A primeira descrição de pacientes com "uma inflamação das meninges, com depósito de material tuberculado na forma de granulações ou na forma caseosa" ocorreu em 1836 (Green, 1842) após a análise de 6 crianças mortas por um quadro de hidrocefalia aguda, 46 anos antes da descrição do $M$. tuberculosis por Robert Koch em 1882 apud Sakula (1982). A partir dos achados em seus pacientes Green (1842) propôs nesta mesma data a introdução de um novo termo médico para descrever os achados em seus pacientes: meningite tubercular. Partindo desses precedentes e com uma série elegante de experimentos, Rich e McCordock (1933) puderam desvendar o mecanismo pelo qual o M. tuberculosis provoca a MTB, vários anos depois.

Após a inalação de partículas contendo $M$. tuberculosis, na maioria dos casos, ocorre controle local da infecção nos pulmões através do desencadeamento de uma cascata inflamatória e elaboração de uma resposta imune predominantemente celular, com ativação de macrófagos e formação de um complexo primário. Nessa fase de infecção primária, apesar da resposta imune inicial, pode ocorrer disseminação linfohematogênica do bacilo, especialmente em indivíduos com algum tipo de imunossupressão e crianças 
menores de 3 anos (Thwaites et al., 2009, 2013). Essa micobacteremia é a responsável pelo alojamento dos bacilos em áreas meníngeas justaependimárias próximas ao espaço subaracnóide. Granulomas isolados podem se formar em toda superfície do cérebro, sendo conhecidos como focos de Rich (Rich; McCordock, 1933).

Caso uma resposta imunológica celular satisfatória não aconteça durante a infecção primária ou ainda, se há perda dos mecanismos de controle imune - nos casos de reativação -, pode ocorrer progressão da doença não apenas nos pulmões, mas em todos os sítios em que o bacilo se alojou, incluindo o SNC (Rich; McCordock, 1933; Donald et al., 2005; Fitzgerald et al., 2005). Além do HIV, outros fatores de risco para o acometimento do SNC incluem o alcoolismo, diabetes, câncer, tratamento com corticoides e medicamentos que bloqueiam a ação do fator de necrose tumoral, como o infliximabe, rituximabe, etarnercept e outros (Thwaites et al., 2009).

A hipótese patogênica mais aceita para a MTB afirma que o quadro clínico é resultante da intensa inflamação decorrente da ruptura de tuberculomas subependimários (focos de Rich) no espaço subaracnoideo. Ocorre um exsudato espesso, gelatinoso ao redor das fissuras silvianas, cisternas basais, tronco encefálico e cerebelo (Rich; McCordock, 1933). Acredita-se que a liberação do $M$. tuberculosis no espaço subaracnoideo provoque uma resposta local celular dependente de linfócitos $T$, com produção do fator de necrose tumoral, interleucinas 8 e 10 e interferon gama (Thwaites; Tran, 2005a). A hipersensibilidade aos antígenos do M. tuberculosis também está implicada com achados inflamatórios característicos no líquido cefalorraquidiano (LCR) e com os sinais meníngeos apresentados por alguns pacientes (Dastur et al., 1995; Donald et al., 2005; Fitzgerald; Haas, 2005). Quando não há ruptura, os focos podem crescer formando grandes tuberculomas ou abscessos que poderiam desencadear sintomas neurológicos focais, sem a meningite (Donald et al., 2005).

A história clínica típica de um paciente com quadro de MTB inclui inicialmente um mal-estar, que evolui com cefaleia (50-80\% dos casos), febre 
usualmente baixa (60-95\%), hiporexia (60-80\%), perda de peso e alterações de comportamento. Em duas ou três semanas ocorre piora da cefaleia, aparecimento de sinais de inflamação meníngea (40-80\%), vômitos (30-60\%), confusão mental (10-30\%) e sinais neurológicos focais, incluindo a paralisia de pares cranianos (30-50\%), hemiparesia (10-20\%) e paraparesia (5-10\%) (Thwaites; Tran, 2005a).

Anemia moderada pode ocorrer, assim como hiponatremia decorrente de uma síndrome hiponatrêmica natriurética (Thwaites; Tran, 2005a). Concomitantemente, pode ocorrer um quadro de TB fora do SNC, especialmente entre imunodreprimidos, sendo a forma miliar uma das mais associadas com a MTB (Kennedy et al., 1979). Na maioria dos casos, no entanto, não há achados clínicos inicias que sugiram o diagnóstico seguro de MTB (Thwaites et al., 2009; Marais et al., 2010b; Brancusi et al., 2012).

O envolvimento do sistema circulatório cerebral, tanto arterial quanto venoso, pode causar complicações como infartos lacunares e, com menor frequência, infartos hemorrágicos, aneurismas e tromboembolismo (Chan et al., 2005). Os infartos podem ser decorrentes de um envolvimento dos vasos cranianos pelas áreas de inflamação e exsudato, com consequente vasculite e obstrução. Esse comprometimento também pode ocorrer com os nervos cranianos, causando paralisia de alguns pares na evolução da doença (Chan et al., 2005; Garg; Sinha, 2011). A gravidade dessas complicações depende da resposta inflamatória cerebral e está fortemente relacionada com o prognóstico (Thwaites; Tran, 2005a).

Outra complicação descrita é hidrocefalia, devido extensão do processo inflamatório para as fissuras silvianas, cisternas basais, tronco encefálico e cerebelo, com impedimento do fluxo liquórico e de sua reabsorção (Rich; McCordock, 1933). A obstrução do aqueduto cerebral - que ocorre com menor frequência - é decorrente da retração do exsudato que envolve o tronco encefálico ou por um tuberculoma localizado na raiz da medula espinhal (Donald et al., 2005). 
$\mathrm{Na}$ evolução clínica do paciente não tratado, pode ocorrer edema cerebral, que causa alterações no nível de consciência e convulsões. Com a progressão do quadro, irritabilidade e apatia evoluem para letargia, confusão mental, torpor e coma. Caso não seja tratado adequadamente, na maioria dos casos ocorre importante piora clínica em cinco a seis semanas com coma profundo, decerebração ou decorticação com rigidez e morte (Donald et al., 2005; Fitzgerald; Haas, 2005).

Apresentações clínicas atípicas também podem ocorrer, incluindo quadros rapidamente progressivos de meningite aguda, que são semelhantes a casos de meningite bacteriana, ou quadros arrastados (meningite crônica), que simulam demência por outras causas (Udani; Dastur, 1970; Donald et al., 2005).

\subsection{Avaliação da gravidade e prognóstico da meningite tuberculosa}

No momento da avaliação inicial do paciente com suspeita de MTB, é útil, para avaliação prognóstica, classificar os doentes em três estágios clínicos de gravidade, baseados no nível de consciência e sinais neurológicos focais (BMRC, 1948):

- Estágio I - Paciente lúcido, sem déficits neurológicos focais ou hidrocefalia.

- Estágio II - Pacientes com letargia, confusão mental; pode apresentar déficits focais moderados, como paralisia de nervo craniano ou hemiparesia.

- Estágio III - Doença avançada com delirium, torpor, coma, convulsões e múltiplas paralisias de nervos cranianos e/ou hemiplegia.

Entre os pacientes sem HIV que se apresentam no estágio I, a mortalidade é de cerca de $20 \%$. Para aqueles na fase II é de $30 \%$ e de $55 \%$ 
para aqueles classificados no estágio III (Thwaites et al., 2004b). Entre os pacientes com HIV, a mortalidade é mais alta para todos os estágios, sendo estimada em 40, 52 e 75\%, respectivamente para os estágios I, II e III (Torok et al., 2011).

\subsection{Tuberculose do sistema nervoso central em pacientes com HIV}

A coinfecção HIV-TB resulta em um risco aumentado de todas as formas de TB. Enquanto em um paciente infectado pelo BK e sem HIV, a chance de desenvolver TB ativa ao longo de toda a vida é de cerca de $10 \%$, em um paciente com HIV essa mesma chance é observada anualmente (Corbett et al., 2003). Além disso, a TB acelera a progressão da doença provocada por HIV, ao aumentar a replicação viral. A maior replicação viral, por sua vez, aumenta a perda de células $\mathrm{TCD}_{4}$, prejudicando a resposta celular responsável pelo controle da TB (Garg; Sinha, 2011).

Os pacientes com aids apresentam uma ampla gama de complicações neurológicas relacionadas à imunodeficiência causada por HIV, entre elas a TB do SNC (Bishburg et al., 1986; Lanjewar et al., 1998; Lucas et al., 1993; Kibayashi et al., 1999; Rana et al., 2000). Entre as doenças neurológicas de causas infecciosas descritas com maior frequência em estudos realizados em países em desenvolvimento (Tabela 2), a TB do SNC constitui a segunda ou terceira causa (Vidal et al., 2005). No maior estudo neuropatológico realizado no Brasil, a TB do SNC foi a quinta doença mais encontrada entre pacientes pesquisados que eram infectados por HIV (Chimelli et al., 1992). 
Tabela 2 - Estudos neuropatológicos de pacientes com aids em países em desenvolvimento

\begin{tabular}{lccccccc}
\hline & $\mathbf{n}$ & NTX & MCC & LPSNC & LEMP & NTB & BACT \\
\hline $\begin{array}{l}\text { ABIDJAN'S } \\
\text { Lucas et al., 1993 }\end{array}$ & 247 & $15 \%$ & $3 \%$ & $1 \%$ & $1 \%$ & $8 \%$ & $5 \%$ \\
$\begin{array}{l}\text { INDIA } \\
\text { Lanjewar et al., 1998 }\end{array}$ & 85 & $13 \%$ & $8 \%$ & -- & -- & $12 \%$ & -- \\
$\begin{array}{l}\text { TANZANIA } \\
\text { Kibayashi et al., 1999 }\end{array}$ & 10 & -- & $10 \%$ & -- & -- & $10 \%$ & $10 \%$ \\
$\begin{array}{l}\text { KENYA } \\
\text { Rana et al., 2000 }\end{array}$ & 75 & $3 \%$ & $5 \%$ & $1 \%$ & -- & $11 \%$ & $5 \%$ \\
$\begin{array}{l}\text { RIO DE JANEIRO } \\
\text { Chimelli et al., 1992 }\end{array}$ & 252 & $34 \%$ & $14 \%$ & $4 \%$ & $1 \%$ & $1 \%$ & $2 \%$ \\
\hline
\end{tabular}

Nota. $\mathrm{n}=$ número de pacientes. NTX $=$ Toxoplasmose do SNC. MCC $=$ Meningoencefalite Criptococócica. LPSNC $=$ linfoma primário do SNC. NTB $=$ Tuberculose do SNC. BACT $=$ infecções bacterianas (meningite e / ou abscessos).

Fonte: Vidal, 2005

Entre os pacientes com diagnóstico de MTB, alguns aspectos são semelhantes entre os aqueles infectados por HIV e aqueles sem o vírus. Destaca-se a característica e duração dos sintomas, a apresentação clínica e os achados radiológicos (Dube et al., 1992; Marais et al., 2010a; Garg; Sinha, 2011). No entanto, as taxas de mortalidade e o número de complicações decorrentes da MTB são habitualmente mais altos entre os infectados por HIV, especialmente se o diagnóstico é tardio (Dube et al., 1992; Katrak et al., 2000; Schutte et al., 2001; Thwaites et al., 2005b; Enberg et al., 2006). A mortalidade é de aproximadamente $25 \%$ entre os HIV negativos, enquanto entre os pacientes com HIV pode chegar a 67\% (Thwaites et al., 2004; Torok et al., 2011).

No que diz respeito à incidência, observa-se também que a MTB ocorre com maior frequência em pacientes HIV positivos quando comparados a pacientes imunocompetentes (Dube et al., 1992; Berenguer et al, 1992). O envolvimento do SNC chega a ser cinco vezes maior entre os pacientes com aids, ocorrendo em $10-20 \%$ dos pacientes coinfectados com TB (Berenguer et al., 1992). Observa-se ainda a presença concomitante de TB fora do SNC de modo mais freqüente entre os pacientes HIV positivos com MTB (Schutte et al., 
2001; Twaites et al., 2005). Usuários de drogas infectados por HIV também têm um risco maior de desenvolver a TB do SNC (Garg et al., 1999).

\subsection{Diagnóstico da meningite tuberculosa}

Entre os fatores associados com a alta letalidade da MTB, um dos principais responsáveis é o diagnóstico tardio (Kennedy; Fallon, 1979; Leonard et al., 1990; Donald et al., 2005; Marais et al., 2012b). Além de suas manifestações clínicas serem inespecíficas e semelhantes a outras infecções do SNC (Katti, 2004), a falta de métodos diagnósticos rápidos e sensíveis constitui uma limitação importante (Bonington et al., 2000; Thwaites et al., 2009; Marais et al., 2010a; Takahashi et al., 2012).

O quadro clássico de MTB é caracterizado por sintomas e sinais clínicos com mais de 5 dias de duração, associados a uma análise do líquido cefalorraquidiano (LCR) revelando pleocitose com predominância linfomonocitária, níveis proteicos maiores que $100 \mathrm{mg} / \mathrm{dL}$ e glicorraquia menor que 40 mg/dL (Ahuja et al., 1994; Kox et al., 1995; Kumar et al., 1999; Thwaites et al., 2002 e 2005; Torok et al., 2007; Puccioni-Sohler; Brandão, 2007; Marais et al., 2010b).

Entretanto, a alteração de todos esses parâmetros liquóricos está presente em menos de $60 \%$ dos pacientes com MTB (Thwaites et al., 2005a, Croda et al., 2010). Ressalta-se ainda a baixa especificidade desses achados: padrões semelhantes podem ser encontrados em outras infecções do SNC como toxoplasmose, meningite criptocóccica, neurossífilis, brucelose, infecções fúngicas e meningoencefalites virais (Garg et al., 1999; Katti et al., 2004; Puccioni-Sohler; Brandão, 2007).

Além disso, ocorrem casos de MTB com padrões liquóricos diferentes daqueles descritos classicamente para esse tipo de meningite (Bishburg et al., 1986; Laguna et al., 1992; Thwaites et al., 2002; Marais et al., 2010a). Há casos com líquor revelando pleocitose com predomínio neutrofílico na fase 
aguda ou sub-aguda da doença. São relatados, ainda que com baixa frequência, LCR com isolamento do BK e sem qualquer alteração quimiocitológica (Karstaedt et al., 1998; Hakim et al., 2000; Puccioni-Sohler; Brandão, 2007; Croda et al., 2010).

Karstaedt et al. (1998) mostraram que 39\% dos pacientes com MTB tinham predomínio de neutrófilos na citologia liquórica e que $22 \%$ deles tinham menos de 5 leucócitos no LCR. No estudo realizado por Caws et al. (2000), também ficou evidente que o aumento no número diferencial de linfócitos não é útil como marcador isolado para fazer o diagnóstico diferencial de MTB com outros tipos de meningites.

Em estudo brasileiro realizado no Rio de Janeiro por Puccioni-Sohler e Brandão (2007), foi mostrado que a maioria dos pacientes com cultura positiva para M. tuberculosis apresentavam LCR com pleocitose neutrofílica. Dois entre os 30 pacientes com MTB tinham o LCR sem alterações bioquímicas ou citológicas. No estudo retrospectivo realizado no Instituto de Infectologia Emílio Ribas (IIER) entre 2000 e 2008, entre os 108 pacientes com diagnóstico definitivo de MTB através de cultura de LCR, 5 casos não apresentavam qualquer alteração quimiocitológica (Croda et al., 2010). Observa-se, portanto, a necessidade da investigação de novos métodos para auxiliar o diagnóstico correto e oportuno da MTB, também em casos atípicos.

\subsection{Aspectos radiológicos no diagnóstico da meningite tuberculosa}

Os avanços nos exames radiológicos do SNC contribuíram para melhorar a acurácia no diagnóstico da MTB (Thwaites et al., 2009; Marais et al., 2010b; Takahashi et al., 2012; Brancusi et al., 2012). A tomografia computadorizada e a ressonância magnética de crânio (TC e RM de crânio) fornecem achados inespecíficos que, quando associados a outros elementos clínicos e laboratoriais, ajudam a estabelecer uma maior probabilidade no diagnóstico presuntivo de MTB (Marais et al., 2010b). 
As alterações classicamente encontradas em pacientes com MTB são; (I) hiperdensidade meníngea basal (pré ou pós-contraste); (ii) hidrocefalia; (iii). imagem(ns) nodular(es) (sugestivas de tuberculoma) e (iv) infartos cerebrais (Berenguer et al., 2003; Garg; Sinha, 2011). Entre essas alterações, a hiperdensidade meníngea basal pré-contraste mostro ser o achado isolado mais específico de MTB (Berenguer et al., 2003; Andronikou et al., 2004).

Nos pacientes HIV positivos com MTB, os achados parecem ser semelhantes àqueles encontrados entre os soronegativos, conforme a revisão sistemática de Marais et al. (2010a). No entanto, Katrak et al. (2000), encontraram menor número de realce meníngeo e hidrocefalia, justificando esses achados pelo fato dos pacientes infectados por HIV terem uma resposta inflamatória reduzida quando comparados àqueles sem HIV.

É interessante observar que doenças neurológicas como a meningite criptocóccica, a toxoplasmose do SNC, a encefalite por citomegalovírus (CMV), - linfoma do SNC e a sacoidose podem produzir achados radiológicos semelhantes à MTB (Foerster et al., 2007; Tan et. al., 2012). Assim como as outras evidências, os achados dos exames de imagem sempre devem ser avaliados em conjunto com as características epidemiológicas, clínicas e laboratoriais dos pacientes com suspeita da MTB (Tan et al., 2012).

Além dos achados nos exames radiológicos do cérebro, é importante mencionar a utilidade dos raios- $X$ simples de tórax, que podem estar alterados (infecção ativa ou sequela de TB antiga) em até $50 \%$ dos pacientes com TB do SNC e HIV (Thwaites; Tran, 2005a). É uma pista fácil, acessível e barata na abordagem diagnóstica de MTB (Garg; Sinha, 2011).

\subsection{Dificuldades no diagnóstico confirmatório da meningite tuberculosa}

A baixa sensibilidade e especificidade dos sintomas neurológicos, achados radiológicos e laboratoriais iniciais na MTB já foram demonstradas em 
diversos trabalhos da literatura (Kent et al., 1993, Thwaites et al. 2002, 2003, 2005a, 2009; Marais et al., 2010a; Ho et al., 2013). Na maioria dos estudos, e também na prática clínica diária, o diagnóstico de MTB é presuntivo, baseado em uma combinação de achados clínicos, laboratoriais e radiológicos (Bhigjee et al., 2007; Thwaites et al., 2009; Marais et al., 2010a, 2010b).

Os métodos confirmatórios tradicionais (baciloscopia e a cultura no LCR) são úteis no diagnóstico específico da MTB. De modo especial, a baciloscopia, que pode ser realizada rapidamente e com baixo custo (Thwaites et al., 2009). No entanto, tanto baciloscopia como cultura estão classicamente associadas à baixa sensibilidade. Um resultado negativo não permite descartar a possibilidade de MTB (Thwaites et al., 2009).

A deteç̧ão do BAAR através da baciloscopia com coloração ZiehlNeelsen é a técnica mais empregada para o diagnóstico de TB em todo 0 mundo. No entanto, essa técnica é pouco sensível na TB extrapulmonar (WHO, 2013). Observa-se uma grande variação de sensibilidade (0 - 69\%) nos estudos de MTB (Ho et al., 2013), mas a maioria deles aponta para uma sensibilidade muito baixa $(3-10 \%)$, tanto em pacientes infectados por HIV como naqueles sem a infecção (Marais et al., 2010a). Fatores como volume da amostra, número de campos examinados, tempo de avaliação das lâminas, experiência do profissional responsável por realizar o exame e o tratamento prévio influenciam essa sensibilidade (Naughten et al., 1981; Traub et al., 1984).

O isolamento microbiológico do M. tuberculosis através da cultura no LCR é o padrão-ouro no diagnóstico da MTB (Thwaites et al., 2009). Ela pode ser realizada através do cultivo no meio sólido de Lowenstein-Jensen (LJ), que requer cerca de $4-8$ semanas para fornecer um resultado definitivo. Além do tempo prolongado necessário para se chegar ao diagnóstico, a sensibilidade na maioria dos estudos varia entre 3,8 a 50\% (Traub et al., 1984; Ogawa et al., 1987; Kent et al., 1993; Marais et al., 2010a).

A cultura em meios líquidos como o Middlebrook 7H12 também é útil 
no diagnóstico de MTB (Thwaites et al., 2009), sendo utilizada em combinação com o cultivo em meio sólido na maioria dos laboratórios. Tem a vantagem de diminuir o tempo de positividade para cerca de duas semanas e há evidencias de sua maior sensibilidade quando comparada ao meio sólido (Venkataswamy et al., 2007).

Sistemas comerciais automatizados como o BACTEC тм 460 TB system $^{\mathrm{TM}}$ (Becton Dickinson Microbiology Systems, Sparks, MD) tem sido utilizados em alguns laboratórios. Trata-se de um método radiométrico em que a amostra é semeada em meio líquido e o crescimento de micobactérias é detectado através da medida dos níveis de ${ }^{14} \mathrm{CO}_{2}$ liberado. É um método mais sensível e mais rápido que a cultura em meio sólido, mas ainda necessita de aproximadamente 14 dias de incubação e é muito dispendioso para ser implementado amplamente em países mais pobres (Leitritz et al., 2001; Kox et al., 1995).

O sistema BACTEC ${ }^{\text {TM }} 460$ tem sido progressivamente substituído pelo BACTEC 960 Mycobacterial Growth Indicator Tube (MGIT) ${ }^{\mathrm{TM}}$, que detecta 0 crescimento micobacteriano através de um método fluorométrico ao invés de utilizar radioisótopos. O IIER utiliza atualmente esse sistema e a cultura em

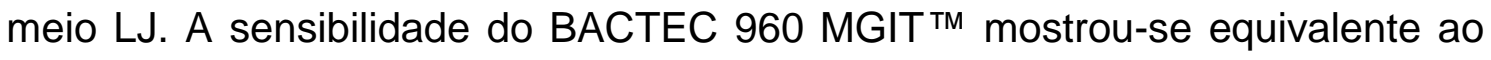
do sistema radiométrico (Leitritz et al., 2001).

Apesar da cultura ser muito lenta para o diagnóstico precoce da MTB, continua sendo um método necessário no diagnóstico, capaz de avaliar plenamente o perfil de sensibilidade do M. tuberculosis. Contudo necessita ser aperfeiçoada, por exemplo, através de uso de maiores volumes de líquor e coletas seriadas (Stewart, 1953; Kennedy; Fallon, 1979; Thwaites et al., 2004a). Seu papel pode ser crucial ao longo do tratamento da MTB para adequação terapêutica, especialmente diante das infecções por cepas multirresistentes de M. tuberculosis (MDR) que pioram o prognóstico da doença (Thwaites et al., 2013). 


\subsection{Diagnóstico da meningite tuberculosa em pacientes infectados por HIV}

Uma revisão sistemática abordando a MTB apontou que diversas características são semelhantes entre pacientes infectados por HIV e aqueles não infectados. A Tabela 3 resume os achados de estudos que descreveram características clínicas, radiológicas e laboratoriais desses pacientes (Marais et al., 2010a).

Apesar dessas semelhanças, também são descritos parâmetros liquóricos atípicos para os infectados por HIV em estudos de boa qualidade metodológica (Bishburg et al., 1986; Laguna et al., 1992; Caws et al., 2000; Croda et al., 2010). Há casos de pacientes com cultura positiva para $M$. tuberculosis no LCR sem qualquer alteração quimiocitológica (Croda et al., 2010). Foi observado também menor contagem total de leucócitos e níveis mais baixos de proteína no LCR desses pacientes (Katrak et al., 2000).

Em estudo realizado no IIER em São Paulo com 108 pacientes infectados por HIV e com diagnóstico de MTB, Croda et al. (2010) observaram que a tríade clínica clássica associada à MTB (febre, cefaleia e sinais meníngeos) estava presente em apenas $15 \%$ dos pacientes com cultura positiva no LCR. As alterações liquóricas típicas (aumento de leucócitos, proteínas e hipoglicorraquia) estavam presentes em apenas 64\% dos casos. Nesse contexto, outros estudos também já demonstraram que pacientes com $\mathrm{CD}_{4}$ menor que 50 células/ $\mu \mathrm{L}$ apresentam menor alteração nos parâmetros liquóricos quando comparados àqueles com $\mathrm{CD}_{4}$ maior que 50 células/ $\mu \mathrm{L}$ (Cecchini et al., 2009; Vidal et al., 2010). Vidal et al. (2010) observaram que aqueles com $\mathrm{CD}_{4}$ abaixo de 50 células $/ \mu \mathrm{L}$ apresentavam menor celularidade total do LCR e maior quantidade de glicose quando comparados àqueles com CD4 maior que 50 células/ $\mu \mathrm{L}$. 
Tabela 3 - Achados clínicos, radiológicos e laboratoriais de pacientes infectados e não infectados pelo HIV com meningite tuberculosa

\begin{tabular}{|c|c|c|}
\hline & HIV positivos* & HIV negativos* \\
\hline \multicolumn{3}{|l|}{ Achados clínicos } \\
\hline Duração sintomas, dias (média/mediana) & $9-42$ & $11-22$ \\
\hline Cefaleia/irritabilidade (\%) & $41-100$ & $22-100$ \\
\hline Febre (\%) & $68-100$ & $45-97$ \\
\hline Náusea/vômito (\%) & $26-50$ & $22-54$ \\
\hline Convulsões (\%) & $3-50$ & $0-64$ \\
\hline Confusão mental (\%) & $30-74$ & $23-73$ \\
\hline Sinais meníngeos (\%) & $19-100$ & $44-100$ \\
\hline Paralisia de pares cranianos (\%) & $13-77$ & $30-52$ \\
\hline Déficit neurológico focal (\%) & $16-80$ & $11-80$ \\
\hline \multicolumn{3}{|l|}{ Gravidade na apresentação (BMRC), \% } \\
\hline I & $0-50$ & $0-34$ \\
\hline ॥ & $35-80$ & $42-82$ \\
\hline III & $0-63$ & $0-88$ \\
\hline \multicolumn{3}{|l|}{$\begin{array}{l}\text { Achados Radiológicos } \\
\text { Rx tórax }\end{array}$} \\
\hline Anormal (\%) & $53-85$ & $33-82$ \\
\hline Sugestivo de TB Miliar (\%) & $10-33$ & $18-44$ \\
\hline \multicolumn{3}{|l|}{ TC/RM de crânio } \\
\hline Anormal $(\%)$ & $55-100$ & $33-82$ \\
\hline Realce meníngeo (\%) & $16-63$ & $6-82$ \\
\hline Hidrocefalia (\%) & $20-72$ & $30-98$ \\
\hline Lesões focais $(\%)$ & $0-60$ & $0-27$ \\
\hline Atrofia cortical (\%) & $5-57$ & $5-17$ \\
\hline \multicolumn{3}{|l|}{ Achados liquóricos } \\
\hline Leucócitos totais $\times 10^{6} / \mathrm{L}$ (média/mediana) & $47-438$ & $11-356$ \\
\hline Linfócitos x 106/L (média/mediana) & $89-219$ & $13-179$ \\
\hline Neutrófilos $\times 10^{6} / \mathrm{L}$ (média/mediana) & $18-69$ & $50-87$ \\
\hline Proteína (mg/dl, média/mediana) & $52-288$ & $78-348$ \\
\hline Glicose (mg/dl, média/mediana) & $23-49$ & $20-50$ \\
\hline Razão glicose líquor/soro (mediana) & $0,27-0,3$ & 0,29 \\
\hline ADA (UI/L)) (média/mediana) & $10-12,6$ & $13,5-16$ \\
\hline Positividade da baciloscopia direta (\%) & $0-69$ & $0-26$ \\
\hline Positividade da Cultura (\%) & $0-88$ & $0-78$ \\
\hline $\begin{array}{l}\text { Contagem de linfócitos CD4 } \\
\text { (células } / \mu L \text { ) (média/mediana) }\end{array}$ & $32-180$ & 248 \\
\hline
\end{tabular}


Croda et al. (2010) observaram que 75\% dos pacientes tinham história de TB prévia, o que pode constituir uma boa pista para o diagnóstico. Cerca de $40 \%$ deles tinham resistência ao menos a uma das drogas de escolha para o tratamento inicial de MTB, o que está associado a um pior prognóstico (WHO, 2013). Ainda que de modo não significativo, $O C_{4}$ menor que 100 células $/ \mu l$ foi associado a uma tendência de maior mortalidade no estudo (Croda et al., 2010), conforme estudos prévios (Cecchini et al., 2007).

Padrões liquóricos semelhantes àqueles apresentados por pacientes com MTB podem ser observados com mais frequência em pacientes infectados por HIV e com diagnóstico de outras doenças neurológicas. Pleocitose com predomínio linfomonocitário e hiperproteinorraquia podem ser encontrados em doentes com meninginte criptococócica, neurossífilis e meningite bacteriana aguda (Livramento et al., 1989; Hinrichsen et al., 1996; Marais et al. 2010a), sendo descritas inclusive coinfecções (Bahls et al., 1986; Gomez-Aranda et al., 1993; Silber et al., 1998). Além disso, o próprio HIV pode ser responsabilizado por meningites "assépticas" e padrões liquóricos semelhantes ao da MTB em pacientes sem quaisquer outras infecções neurológicas (Hollander; Stringari, 1987; Appleman et al., 1988; Hollander et al., 1988; Ho et al., 2013).

\subsection{Critérios e categorias diagnósticas de meningite tuberculosa}

O diagnóstico etiológico rápido e confiável continua a ser um desafio médico importante para o controle adequado da MTB (Ho et al., 2013). Na maioria das vezes, médicos e pesquisadores definem o diagnóstico de modo presuntivo baseado em uma série de variáveis clínicas, laboratoriais e radiológicas. A baixa frequência de diagnósticos definitivos dificulta a avaliação de novas metodologias diagnósticas que poderiam apresentar um padrão de positividade maior que a cultura no LCR (Traub et al., 1984; Ogawa et al., 1987; Kent et al., 1993; Marais et al., 2010b). No desenvolvimento de novos métodos diagnósticos, deve-se não apenas determinar e comparar o desempenho de um novo teste com o do padrão-ouro, mas estudar o novo 
teste como parte de uma estratégia diagnóstica composta por outros exames e observações clínicas (van Stralen et al., 1999).

Alguns estudos tentaram estabelecer critérios e categorias diagnósticas para a avaliação de novas ferramentas na investigação da MTB (Ahuja et al., 1994; Kox et al., 1995; Kumar et al., 1999; Thwaites et al., 2002; Torok et al., 2007). No entanto, esses critérios são muito diferentes entre si, o que torna difícil a comparação entre os estudos. A ausência de um critério diagnóstico padrão e universal torna difícil a avaliação de novas metodologias diagnósticas: impede a comparação dos dados existentes em pesquisas prévias e limita o progresso na investigação da MTB (Marais et al., 2010b).

Baseado nessas dificuldades, um grupo de pesquisadores especializados em MTB se reuniu em 2009, na Cidade do Cabo (África do Sul), com o objetivo de estabelecer critérios diagnósticos e definições de caso para serem utilizados nos estudos da MTB, inclusive na investigação de novos métodos diagnósticos. O resultado desse trabalho foi publicado no periódico Lancet em 2010 (Marais et al., 2010b).

Quatro categorias diagnósticas foram criadas, baseadas em uma pontuação que gradua a importância de diversos critérios clínicos, liquóricos, radiológicos e a evidência de TB fora do SNC. A partir da soma da pontuação nesses critérios, os pacientes em investigação de MTB são alocados em uma das 4 categorias diagnósticas: i. MTB Definitiva; ii. MTB Provável; iii. MTB Possível e iv. Não MTB (outra etiologia identificada). Esses critérios e categorias diagnósticas serão explicados detalhadamente no capítulo de métodos, uma vez que foram utilizados na investigação dos casos desta tese.

\subsection{Biologia molecular no diagnóstico de meningite tuberculosa}

Considerando as dificuldades no diagnóstico da MTB, as técnicas de biologia molecular - especialmente a amplificação e detecção do ácido desoxirribonucléico (DNA) do M. tuberculosis (Takahashi et al., 2012), através 
da reação em cadeia da polimerase (PCR),- têm apresentado resultados promissores nos últimos anos (Thwaites et al., 2013).

Essas técnicas tem sido avaliado por diferentes pesquisadores no Brasil (Martins et al., 2000; Puccioni-Sohler; Brandão, 2007) e em todo o mundo (Shankar et al., 1991; Donald et al., 1993; Scarpellini et al., 1995; Kox et al., 1995; Martins et al., 2000; Heringer et al., 2005; Takahashi et al., 2006; Desai et al., 2006; Takahashi et al., 2012), com resultados de sensibilidade habitualmente superiores aos da cultura e com alta especificidade.

Duas revisões sistemáticas analisaram diversas técnicas da PCR disponíveis para diagnóstico de MTB, tanto métodos comerciais como ensaios in house (Pai et al., 2003; Dinnes et al., 2007). A especificidade da PCR nos diferentes estudos analisados variou entre 90 e 100\%. No entanto, a sensibilidade apresentou ampla divergência entre os estudos, com um valor médio de 56\% (Pai et al., 2003). Entre as diferenças apresentadas nos estudos, destacam-se diferentes genes alvo, métodos distintos de extração do DNA, volumes diferentes de LCR utilizado e modo de realização da técnica da PCR (Dinnes et al., 2007).

Devido ao seu alto valor preditivo positivo, a metodologia de amplificação de ácido nucleico para $M$. tuberculosis no $L C R$ se tornou um teste de primeira linha para definir o diagnóstico de MTB, quando seus resultados são positivos. No entanto, seu valor preditivo negativo é baixo, indicando que um resultado negativo, assumido de modo isolado, não é capaz de excluir a presença de MTB (Dinnes et al., 2007; Thwaites et al., 2009).

Umas das técnicas de PCR que vem apresentado maior sensibilidade na literatura para o diagnostico de MTB é denominada PCR aninhada (n-PCR, do inglês nested PCR) (Scarpellini et al., 1995, Takahashi et al., 2005, 2006, 2007, 2012). Esse método pode aumentar a sensibilidade e a especificidade da amplificação do DNA quando comparada com as reações da PCR convencionais (Liu et al., 1994; Takahashi et al., 2012). Scarpellini et al. (1995) mostraram elevada acurácia diagnóstica dessa técnica da PCR em pacientes 
com HIV e coinfecção com MTB. No entanto, é um método que precisa ser mais bem estudado em contextos clínicos e epidemiológicos diversos, especialmente em países em que a TB é endêmica (Dinnes et al., 2007).

A n-PCR é uma técnica derivada da PCR convencional com a intenção de aumentar a eficiência da amplificação dos ácidos nucleicos que são alvos da reação (Takahashi et al., 2012). A n-PCR utiliza duas sequências de iniciadores (primers), que são usados em duas reações sucessivas da PCR. O primeiro iniciador amplifica a região alvo no DNA do micro-organismo procurado. O segundo iniciador é utilizado para amplificar um alvo que está contido dentro do produto amplificado (amplicons) da primeira reação da PCR. Por isso, na técnica da n-PCR, caso um material genético seja amplificado erroneamente na primeira reação (por não ser o alvo de ligação de iniciadores específicos do micro-organismo procurado), ele não será amplificado na segunda reação. Essa propriedade aumenta a especificidade do teste, além da vantagem do aumento de sensibilidade, conseguida pela "dupla amplificação" do DNA alvo procurado (Takahashi et al., 2012).

Outra técnica de amplificação de ácido nucleico que vem ganhando destaque no diagnóstico da MTB é a PCR em tempo real (Takahashi et al., 2006, 2012). A PCR em tempo real (RT-PCR, do inglês real time PCR) oferece a vantagem da amplificação e detecção simultânea dos produtos amplificados, uma grande inovação quando comparada à PCR convencional, na qual os produtos só são detectados no fim do procedimento. O mesmo recipiente é utilizado para amplificação e detecção informatizada em "tempo real", sem transferência de amostras, sem adição de reagentes ou separação em gel, reduzindo o risco de contaminações (Takahashi et al., 2012; Patel et al., 2013). Além disso, o método também tem a vantagem de ser mais rápido (menos de 2 horas de procedimento laboratorial) e fácil de ser implantado em diversos serviços (Espy et al., 2006).

Características como a ótima sensibilidade e especificidade, o baixo risco de contaminação, a facilidade e rapidez para processamento das amostras fazem da RT-PCR uma alternativa muito atraente para o diagnóstico 
microbiológico de muitas infecções (Espy et al., 2006). A técnica da RT-PCR pode ser combinada à metodologia da n-PCR, para constituir a PCR em tempo real aninhada (nRT-PCR, do inglês nested Real Time PCR), um método interessante no diagnóstico de MTB, apesar de pouco estudado (Takahsahi et al., 2012).

Patel et al. (2013) desenvolveram o primeiro estudo em um centro de pesquisa na África do Sul para avaliar a plataforma GeneXpert MTB/RIF ${ }^{8}$ exclusivamente em pacientes com suspeita de MTB, com bons resultados de sensibilidade e especificidade. Essa plataforma utiliza uma metodologia automatizada da n-PCR combinada à detecção em tempo real, semelhante à técnica da nRT-PCR. É muito prática no diagnóstico de TB pulmonar, com ótimos resultados em diversos países (WHO, 2013), ainda que seu desempenho em amostras paucibacilares seja muito variável (Walusimbi et al., 2013). O GeneXpert MTB/RIF® tem distribuição limitada em nosso país, entre outros motivos por causa de seu alto custo. Está em fase de implantação nos serviços públicos do Estado de São Paulo. Com os incentivos da OMS, a praticidade da sua execução e seus resultados promissores (WHO, 2013), é inegável que em breve essa plataforma também estará disponível no serviço público brasileiro. Após avaliação por estudos mais abrangentes, pode ser uma ferramenta muito útil também no diagnóstico da MTB.

\subsection{Justificativa do estudo}

No contexto apresentado anteriormente, destaca-se que:

(I) a TB é uma doença prevalente no Brasil e a MTB é sua forma de apresentação mais grave, com elevada morbimortalidade;

(ii) o diagnóstico oportuno da MTB é o fator mais importante na melhora do prognóstico da doença e na prevenção de sequelas neurológicas;

(iii) o padrão-ouro para o diagnóstico de MTB (cultura no líquor) é um método demorado e com resultados variáveis de sensibilidade; 
(iv) existem poucos estudos prospectivos utilizando a PCR em tempo real como ferramenta diagnóstica de MTB;

(vi) não há uma técnica da PCR autorizada pelo Food and Drug Administration (FDA) ou pela Agência Nacional de Vigilância Sanitária (ANVISA) para o diagnóstico de MTB. Além disso, as técnicas moleculares comerciais que são usadas para diagnóstico de MTB não estão amplamente disponíveis e apresentam resultado de sensibilidade muito variável.

Faz-se necessário, portanto, a realização de um estudo com pacientes com suspeita de MTB para avaliar métodos diagnósticos alternativos, como a nRT-PCRI, que combina duas técnicas promissoras de amplificação de ácido nucleico do $M$. tuberculosis. 
2. Objetivos 


\subsection{Geral}

Avaliar o valor diagnóstico da nRT-PCR na investigação de pacientes com MTB.

\subsection{Específicos}

a) Determinar a sensibilidade e especificidade da nRT-PCR no diagnóstico de pacientes com confirmação microbiológica de MTB em estudo prospectivo.

b) Determinar a sensibilidade e especificidade da nRT-PCR em estudo retrospectivo realizado em dois hospitais da rede pública do Estado de São Paulo.

c) Determinar a proporção de pacientes com resultado positivo da nRT-PCR em amostras de LCR de pacientes com suspeita de MTB no estudo prospectivo e no estudo retrospectivo, conforme categorias diagnósticas de MTB. 
3. MÉTOdos 


\subsection{Desenho do estudo}

Estudo observacional composto por uma fase prospectiva e outra retrospectiva:

\section{Estudo prospectivo}

Realizado em São Paulo no Instituto de Infectologia Emílio Ribas (IIER), entre novembro de 2007 e janeiro de 2010. Incluiu pacientes hospitalizados com sintomas neurológicos, conforme os critérios de inclusão adotados no estudo.

Quando um caso de doença neurológica aguda com suspeita de MTB era internado, o pesquisador era convocado para avaliar o paciente. $O$ pesquisador avaliava os pacientes para verificar se preenchiam os critérios de inclusão no estudo. Variáveis demográficas, clínicas, radiológicas e laboratoriais dos pacientes foram coletadas (Anexo A) e agrupadas em um banco de dados eletrônico. Os pacientes incluídos no estudo foram acompanhados até o momento da alta hospitalar ou óbito.

\section{Estudo retrospectivo}

O estudo retrospectivo foi realizado em dois centros de pesquisa de São Paulo: Instituto de Infectologia Emílio Ribas (IIER), Centro de Referência e Treinamento em DST/AIDS (CRT DST/AIDS). O estudo foi aprovado pelo Hospital das Clínicas da Faculdade de Medicina, mas não foram incluídos pacientes desse instituto. O período de inclusão de casos foi entre junho de 2010 e julho de 2012.

Em uma reunião com membros da Divisão de Controle da Tuberculose do Centro de Vigilância Epidemiológica da Secretaria de Estado de Saúde do Estado de São Paulo (CVE-SES/SP), com médicos do IIER e CRT DST/AIDS, 
propôs-se a realização de um estudo retrospectivo para avaliar o valor do teste na rotina diagnóstica desses hospitais.

Os pacientes com sintomas neurológicos foram incluídos nessa fase se o médico assistente julgasse conveniente a coleta de LCR na investigação diagnóstica. Além de ser enviado para os procedimentos de rotina (exame quimiocitológico, Gram, cultura, látex para bactérias e fungos, tinta da china, VDRL) o LCR desses pacientes também foi enviado para pesquisa de $M$. tuberculosis através da nRT-PCR no Instituto Adolfo Lutz (IAL).

Posteriormente, foi realizada uma revisão dos prontuários dos pacientes para os quais foi solicitada a nRT-PCR. Variáveis demográficas, clínicas, radiológicas e laboratoriais dos pacientes foram coletadas (Anexo A) e agrupadas em um banco de dados eletrônico. Os pacientes que não preenchessem os critérios de inclusão ou aqueles que não tivessem informações clínicas necessárias para sua categorização diagnóstica foram excluídos da análise da fase retrospectiva.

A seguir, são descritos os procedimentos que foram idênticos para a fase prospectiva e para a fase retrospectiva.

\subsection{Fluxo de recrutamento dos casos e critérios de inclusão}

Foi incluída uma série de pacientes adultos e pediátricos avaliados no Pronto Socorro dos centros de pesquisa. Foi realizada uma divulgação da pesquisa a todos os médicos que trabalham no Pronto Socorro.

Para serem incluídos, os pacientes deveriam apresentar um ou mais dos seguintes achados clínicos de doença neurológica aguda: cefaleia, irritabilidade, vômitos, febre, rigidez de nuca, convulsões, déficits neurológicos focais, alteração de consciência e letargia.

Após esclarecimento do doente ou responsável quanto à natureza da pesquisa, os pacientes que apresentavam critérios de inclusão foram 
convidados a participar do estudo. Manifestaram sua livre vontade em participar da pesquisa ao assinarem o termo de consentimento livre e esclarecido (TCLE: Anexo B).

Os critérios de exclusão do estudo foram os seguintes: $i$. paciente não ter sido submetido à coleta de LCR; ii. amostra de LCR não ter sido submetida à cultura de micobactérias; iii. amostra insuficiente de LCR para a realização dos ensaios de biologia molecular (menor que $2 \mathrm{~mL}$ ); iv. ausência de TCLE.

Após inclusão no estudo, os pacientes foram submetidos à anamnese, exame físico, exames radiológicos e exames laboratoriais, incluindo a coleta de LCR.

\subsection{Categorias diagnósticas dos pacientes com suspeita de MTB}

A partir dos dados coletados, em ambas as fases do estudo foram utilizados diversos critérios clínicos, radiológicos e laboratoriais para categorizar os pacientes com suspeita de MTB, conforme já descrito em outros trabalhos da literatura (Thwaites et al., 2002; Torok et al., 2007; Marais et al., 2010a,b).

Foram utilizadas duas metodologias de categorização dos pacientes. Uma delas foi elaborada a partir da revisão da literatura e a outra foi uma categorização padronizada internacional (Marais et al., 2010b).

Critérios e categorias diagnósticas propostas a partir da revisão da literatura

Para realizar a classificação dos pacientes em categorias diagnósticas de MTB, foram utilizados os seguintes critérios adaptados dos estudos prévios (Ahuja et al., 1994; Kox et al., 1995; Kumar et al., 1999; Brienze et al., 2000; Thwaites et al., 2002; Torok et al., 2007): 
a. Sintomas descritos pelo paciente e/ou acompanhante;

b. Achados iniciais do exame físico e exame neurológico, incluindo a graduação clínica da gravidade do paciente com suspeita de MTB (BRMC, 1948) e a mensuração da Escala de Coma de Glasgow (ECG);

c. Achados da tomografia de crânio;

d. Parâmetros liquóricos (citologia, bioquímica, GRAM, baciloscopia, látex para bactérias e para fungos, VDRL, Tinta da China);

e. Culturas no líquor (bactérias, fungos e micobactérias);

f. Cultura, baciloscopia e/ou histologia demonstrando micobactéria em sítios fora do SNC (pulmão, linfonodos, vértebra, sangue, peritônio, urina), solicitados conforme a suspeição clínica;

g. PCR para outros micro-organismos (Toxoplasma gondi, JC vírus, CMV, EBV) no líquor, quando apropriados na investigação diagnóstica;

h. Diagnóstico de condições clínico-metabólicas, doença sistêmica com repercussão neurológica ou doença neurológica primária de etiologia não infecciosa;

i. Melhora dos sintomas neurológicos sem instituição de terapêutica específica.

De acordo com os dados encontrados, os pacientes foram individualmente classificados em quatro categorias diagnósticas de MTB, devidamente especificadas abaixo e resumidas na Figura 1:

\section{MTB Definitiva}

- Cultura positiva para M. tuberculosis ou BAAR positivo no líquor ou biópsia do sistema nervoso central com presença de BAAR. 
II. MTB Provável

- Alteração liquórica compatível com MTB:

- Pleocitose (> 5 leucócitos x 106/L);

- Proteinorraquia $>45 \mathrm{mg} / \mathrm{dL}$;

- Glicorraquia $<40 \mathrm{mg} / \mathrm{dL}$

- Cultura ou baciloscopia positiva para M. tuberculosis fora do SNC ou biópsia evidenciando BAAR fora do SNC;

- Exclusão de outras doenças do sistema nervoso central.

\section{MTB Possível}

- Alteração liquórica compatível com MTB:

- Pleocitose (> 5 leucócitos x 106/L);

- Proteinorraquia $>45 \mathrm{mg} / \mathrm{dL}$;

- Glicorraquia $<40 \mathrm{mg} / \mathrm{dL}$

- Associada com três ou mais itens entre os critérios abaixo:

a. Mais de sete dias de sintomas/sinais neurológicos;

b. Tuberculose prévia;

c. Razão entre glicose liquórica e glicose sérica menor que 0,5 (GLIC[ICr] /GLIC[ser] < 0,5);

d. TC de crânio com imagem sugestiva de tuberculose do SNC (realce meníngeo, hidrocefalia, lesões focais, infartos cerebrais);

e. Alteração de consciência (coma ou confusão mental); 
f. Déficits neurológicos focais.

- Exclusão de outras doenças do sistema nervoso central.

\section{Não MTB}

- Diagnóstico de outras doenças do sistema nervoso central confirmado pelos critérios mencionados.

A alocação dos indivíduos nas categorias diagnósticas propostas a partir da literatura ocorreu do seguinte modo: pacientes com suspeita clínica de MTB que entraram no estudo foram inicialmente alocados na categoria "MTB Provável" ou "MTB Possível", conforme os achados clínicos, radiológicos e liquóricos iniciais. Os resultados de investigações subsequentes determinaram a categoria diagnóstica final dos pacientes.

Por exemplo, um paciente inicialmente classificado como "MTB Provável" migraria para a categoria "MTB Definitiva", caso posteriormente viesse a ter uma cultura positiva para $M$. tuberculosis no LCR. Também poderia ocorrer que um paciente da categoria "MTB Possível" ou "MTB Provável" migrasse para "Não MTB", caso fosse estabelecido um diagnóstico alternativo (p.ex.: crescimento de Cryptococcus neoformans na cultura de LCR). Outra situação que poderia ocorrer seria o paciente manter-se na categoria que foi alocado inicialmente, pois não foram encontradas outras evidências diagnósticas mais conclusivas. 


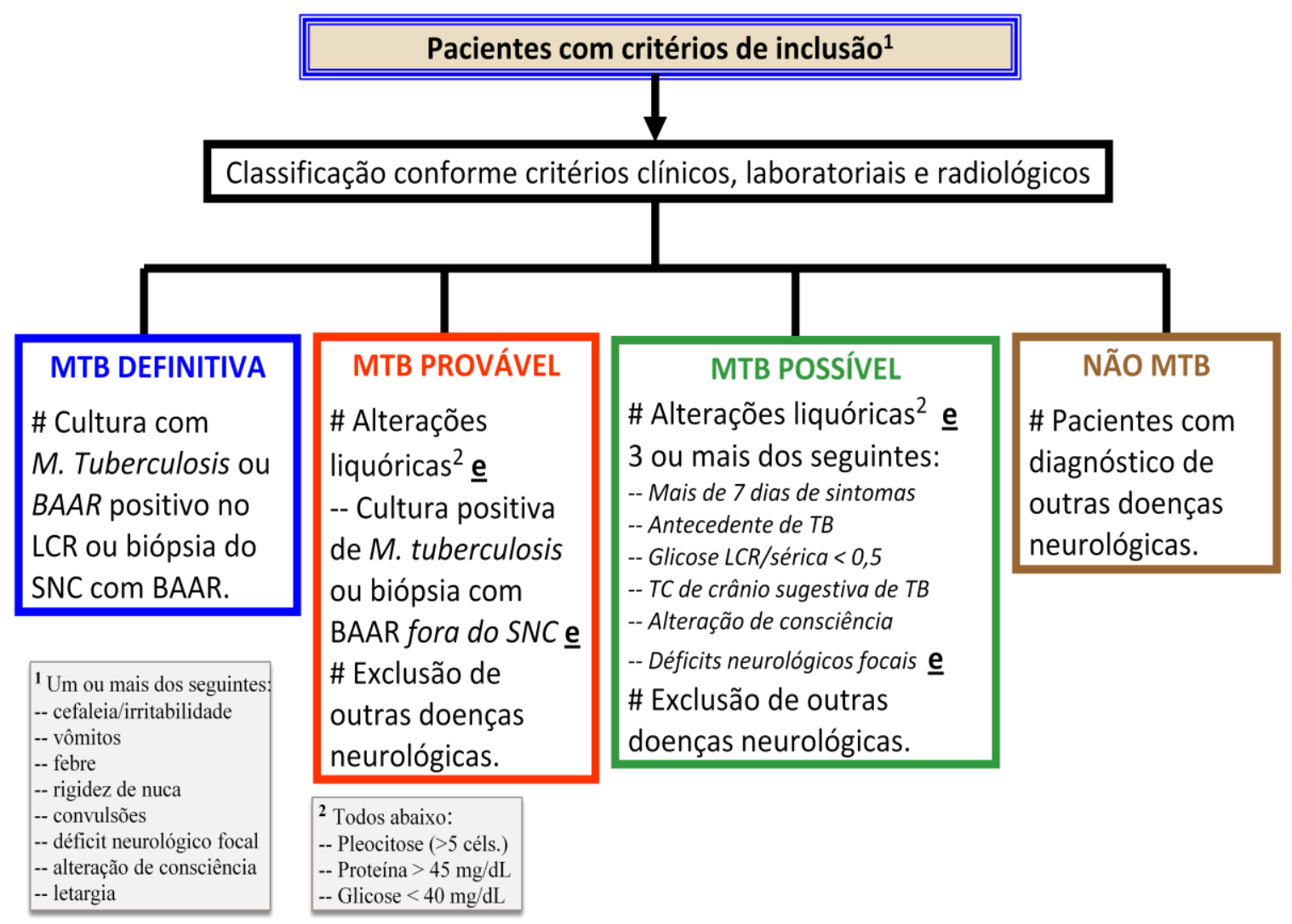

MTB = Meningite Tuberculosa, BAAR = Bacilo álcool ácido resistente; $L C R=$ Líquido cefalorraquidiano; SNC = Sistema Nervoso Central

Figura 1 - Categorias diagnósticas dos pacientes incluídos propostas a partir da revisão da literatura

Critérios e categorias diagnósticas propostas por Marais et al. (2010b)

Durante a realização do presente estudo, foi publicado um trabalho com uma proposta de critérios e categorização de casos suspeitos de MTB, para uso padronizado internacional em pesquisas de investigação de MTB (Marais et al., 2010b).

Os critérios utilizados por Marais et al. (2010b) para incluir os pacientes com suspeita de MTB foram os mesmos adotados no presente estudo. Para a alocação dos pacientes nas categorias diagnósticas de MTB, os autores criaram um escore diagnóstico baseado nos critérios descritos na Tabela 4: 
Tabela 4 - Critérios e escore para a classificação dos pacientes nas categorias diagnósticas internacionais padronizadas de MTB

\begin{tabular}{|c|c|c|}
\hline Tipo de critério & Especificação do critério & Escore \\
\hline CLÍNICO & & (máx=6) \\
\hline E01 & Duração sintomas maior que 5 dias & 4 \\
\hline E02 & $\begin{array}{l}\text { Sintomas sistêmicos sugestivos de TB (um ou mais dos seguintes) } \\
\text { perda de peso, sudorese noturna, tosse mais } 2 \text { semanas. }\end{array}$ & 2 \\
\hline E03 & Historia de contato recente com individuo com TB & 2 \\
\hline E04 & Déficit neurológico focal (excluindo paralisia de nervo craniano) & 1 \\
\hline E05 & Paralisia de nervo craniano & 1 \\
\hline E06 & $\begin{array}{l}\text { Alteração de consciência (confusão mental, rebaixamento nível } \\
\text { consciência, bradpsiquismo, convulsão) }\end{array}$ & 1 \\
\hline LIQUÓRICO & & (máx=4) \\
\hline E07 & Aparência do líquor (clara ou xantocrômica, i.e., não purulenta) & 1 \\
\hline E08 & Entre 10 - 500 células no LCR & 1 \\
\hline E09 & Predominância linfomonocitária (>50\%) & 1 \\
\hline E10 & Concentração de proteína maior que 1g/L (100mg/dL) & 1 \\
\hline E11 & $\begin{array}{l}\text { Razão entre glicose LCR/glicose soro menor que } 50 \% \text { ou } \\
\text { concentração absoluta menor que } 2.2 \mathrm{mmol} / \mathrm{L}(40 \mathrm{mg} / \mathrm{dL})\end{array}$ & 1 \\
\hline RADIOLÓGICO & & $(m a ́ x=6)$ \\
\hline E12 & Hidrocefalia & 1 \\
\hline E13 & Realce meníngeo basal (após contraste) & 2 \\
\hline E14 & Tuberculoma & 2 \\
\hline E15 & Infarto cerebral & 1 \\
\hline E16 & Hiperdensidade meníngea basal (pré contraste) & 2 \\
\hline TB FORA DO SNC & & (máx=4) \\
\hline E17 & $R x$ tórax sugestivo de TB ativa (sinais de $T B=2 ; T B$ miliar=4) & 2 ou 4 \\
\hline E18 & $\begin{array}{l}\text { TC, US ou RM com evidência de TB fora do SNC (p.ex.: } \\
\text { linfadenomegalia torácica ou abdominal com hipoatenuação central) }\end{array}$ & 2 \\
\hline E19 & $\begin{array}{l}\text { BAAR ou cultura positiva para M tuberculosis de outro sítio (escarro, } \\
\text { linfonodo, urina, sangue, etc.) }\end{array}$ & 4 \\
\hline \multirow[t]{2}{*}{ E20 } & PCR comercial positivo para TB em outro sítio & 4 \\
\hline & PONTUAÇÃO MÁXIMA TOTAL & 20 \\
\hline
\end{tabular}

Nota: Em todos os casos, devem ser excluídos diagnósticos alternativos (p.ex.: Criptococose do Sistema Nervoso Central (SNC), Toxoplasmose do SNC, Linfoma do SNC, Meningite Bacteriana, Neurolues, LEMP, CMV do SNC)

Fonte: Adaptado de Marais et al. (2010b)

A partir do banco de dados eletrônico com as variáveis clínicas, laboratoriais e radiológicas dos pacientes do presente estudo, observou-se a presença de todos os critérios necessários para a categorização dos pacientes nessa padronização internacional. Dessa forma, optou-se por também classificar os pacientes conforme as categorias de Marais et al. (2010b), para que os resultados pudessem ser mais bem contextualizados na literatura internacional.

A alocação dos indivíduos nas categorias diagnósticas de Marais et al. (2010b) ocorreu do seguinte modo: conforme os critérios da Tabela 4, todos os pacientes receberam pontuações iniciais e foram alocados na categorias "MTB 
Provável" e "MTB Possível". Aqueles com pontuação menor que seis não foram classificados inicialmente. Quando os resultados dos exames mais conclusivos se tornaram disponíveis, novas pontuações foram atribuídas aos pacientes. De acordo com a soma final dos pontos, cada paciente foi alocado em uma das quatro categorias diagnósticas definidas abaixo: i. "MTB Definitiva"; ii. "MTB Provável”; iii. "MTB Possível" e iv. "Não MTB".

\section{MTB Definitiva}

- Os pacientes que apresentaram um dos critérios abaixo:

i. Presença de BAAR no LCR ou M. tuberculosis isolado na cultura do LCR;

ii. BAAR observado no contexto histológico compatível com tuberculose no cérebro ou na medula espinhal ou com sinais de meningite visíveis (necropsia).

\section{MTB Provável}

- Pontuação no escore diagnóstico de 10 ou mais pontos (quando TC de crânio não estiver disponível) ou de 12 ou mais pontos (quando TC de crânio estiver disponível), associado com à:

— Exclusão de diagnósticos etiológicos alternativos.

\section{MTB Possível}

- Pontuação no escore diagnóstico entre 6 - 9 pontos (quando TC de crânio não estiver disponível) ou entre 6 - 11 pontos (quando TC de crânio estiver disponível), associado com à:

- Exclusão de diagnósticos etiológicos alternativos.

\section{Não MTB}

— Diagnóstico alternativo estabelecido, com ausência de diagnóstico 
definitivo de MTB ou de outros sinais convincentes de doença concomitante.

\subsection{Fluxo laboratorial e análise do líquor}

Em ambas as fases do estudo, as amostras de LCR coletadas dos pacientes foram encaminhadas ao Laboratório do IIER e ao Laboratório do CRT DST/Aids conforme a rotina de cada serviço.

Ocorreu mascaramento das equipes responsáveis pelo processamento do LCR nos laboratórios de cada serviço e no Laboratório de Meningites Bacterianas da Seção de Imunologia do IAL, que realizava as reações da PCR. Não houve comunicação entre os laboratórios, de modo que não foi possível o conhecimento dos resultados das análises do LCR realizadas por cada um deles, de modo a eliminar possíveis vieses laboratoriais.

Os laboratórios dos serviços envolvidos no estudo (IIER, CRTDST/Aids) foram responsáveis pela aferição dos parâmetros liquóricos e pelas culturas no LCR. Outros exames específicos foram solicitados conforme a suspeita clínica. As variáveis liquóricas analisadas estão citadas abaixo:

- Citologia: contagem do número de hemácias e leucócitos e citologia diferencial - linfócitos, monócitos, neutrófilos, eosinófilos, plasmócitos;

- Bioquímica: dosagem de proteína, glicose, cloreto, lactato e enzima adenosina deaminase (ADA);

- Coloração Gram para pesquisa de bactérias Gram negativas e Gram positivas;

- Baciloscopia com coloração Ziehl-Neelsen para pesquisa de BAAR;

- Semeadura em meio sólido Lowenstein-Jensen e em meio líquido (BACTEC 960 MGIT TM $^{\text {T }}$

- Semeadura em meio sólido de cultura para bactérias e fungos. 
Após a coleta das amostras de LCR que seriam submetidas à rotina de cada serviço, também foi coletado entre $2-3 \mathrm{~mL}$ de LCR em tubo tipo "criovial" separado das amostras anteriores. Esse volume foi encaminhado em um prazo máximo de 2 dias para o Laboratório de Meningites Bacterianas da Seção de Imunologia do IAL. As amostras que não foram encaminhadas no mesmo dia foram armazenadas a $-70^{\circ} \mathrm{C}$ e transportadas seguindo normas de segurança (portaria no 1.985 de 25/10/2001) da Agência Nacional de Vigilância Sanitária (ANVISA).

\subsection{Reações em cadeia da polimerase}

A nRT-PCR foi a principal técnica de biologia molecular avaliada em ambas as fases do presente estudo. Resultados de outros trabalhos (Takahashi et al., 2006, 2012) permitiram levantar a hipótese que essa metodologia apresentaria o melhor desempenho, associada ao menor custo e menor tempo de execução.

Também foi avaliado o desempenho de outros formatos da técnica da PCR: a convencional, a nested PCR ( $n-P C R$ ) e a PCR em tempo real (RTPCR), essa última realizada diretamente no DNA extraído, sem prévia amplificação.

Conforme descrito a seguir, a preparação do ensaio da nRT-PCR conta com passos intermediários. Um desses passos é a PCR convencional que gera produtos para serem usados no ensaio da n-PCR, sem o tempo real (RT). No estudo prospectivo, criou-se mais um passo para avaliar essas duas técnicas ao se analisar por eletroforese tanto os produtos da PCR convencional como os da n-PCR.

Preparo e concentração da amostra

O volume total de LCR coletado foi submetido à homogeneização em 
misturador tipo "vortex" e uma alíquota de $1 \mathrm{~mL}$ desse total foi separado utilizando-se ponteiras com bloqueio - em um novo tubo de rosca. Esta alíquota $(1 \mathrm{~mL})$ do $L C R$ foi submetida à centrifugação por 15 minutos a $8.000 \mathrm{~g} \mathrm{a}$ $4^{\circ} \mathrm{C}$, para concentração das células presentes na amostra, processo de centrifugação similar àquele realizado antes da semeadura em meios de cultura para micobactérias.

Após esse procedimento, $500 \mu \mathrm{L}$ do sobrenadante do LCR foram desprezados e os $500 \mu \mathrm{L}$ restantes, com o precipitado de células, foram submetidos à extração e purificação do DNA.

\section{Extração e purificação}

Para a extração do ácido nucléico foi utilizado Kit comercial composto de colunas de sílica da marca Qiagen (QIAamp DNA Mini Kit@; Qiagen, Valencia, CA), de acordo com as instruções do fabricante e com seguintes modificações:

(i) aos $500 \mu \mathrm{L}$ de LCR foram adicionados $50 \mu \mathrm{L}$ de solução de lisozima $(200 \mathrm{mg} / \mathrm{mL})$ e $50 \mu \mathrm{L}$ de solução de mutanolisina $(375 \mathrm{U} / \mathrm{mL})$;

(ii) A mistura foi submetida a um período de incubação a $37^{\circ} \mathrm{C}$ por 2 horas ou por um período de 12 a 16 horas durante a noite (overnight), para promover o rompimento da parede bacteriana.

Após estas etapas, seguiu-se o protocolo original da Qiagen®, resultando em um volume final de $50 \mu \mathrm{L}$ de DNA extraído e purificado, que foi mantido a $-20 \stackrel{\circ}{\circ}$ até o momento do uso. As reações da PCR e n-PCR foram realizadas em dois passos: 
Realização das reações em cadeia da polimerase

As reações da PCR foram realizadas em dois passos, sendo o primeiro passo a amplificação para aumento da quantidade de DNA alvo através da PCR convencional, que gerou o produto (amplicom) a ser utilizado nas próximas reações da PCR nested (segundo passo), tanto no formato convencional (n-PCR) como em tempo real (nRT-PCR).

PCR convencional: primeiro passo

As reações da PCR foram realizadas utilizando-se uma mistura com volume total de $50 \mu \mathrm{L}$ constituída de: tampão de reação $(10 \mathrm{mM}$ Tris-HCL pH

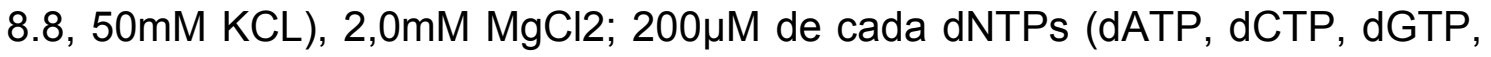
dTTP); $0,4 \mu \mathrm{M}$ de cada primer, $1 \mathrm{U}$ da enzima Taq DNA polimerase e $10 \mu \mathrm{L}$ de DNA extraído.

Foi escolhido o gene mpt64 nas reações da PCR por demonstrar a melhor sensibilidade e especificidade quando comparado a outros alvos (Shankar et al, 1991; Lee et al., 1994; Liu et al., 1994; Rafi et al., 2007; Takahashi et al., 2005, 2012). Foram utilizados os iniciadores (primers) externos F1 e R1 para amplificação do primeiro produto de 239pb, cujas sequências estão descritas na Tabela 5.

O ciclo para amplificação consiste em uma desnaturação a $96^{\circ} \mathrm{C}$ por 3 minutos: a amplificação do produto foi realizada com uma sequência de 35 ciclos, cada um deles composto de $95^{\circ} \mathrm{C}$ por 30 segundos para desnaturação do DNA molde, $60^{\circ} \mathrm{C}$ por 30 segundos para a hibridização dos primers e $72^{\circ} \mathrm{C}$ por 1 minuto para a extensão das novas cadeias. Ao final dos ciclos, seguiu-se um aquecimento a $72^{\circ} \mathrm{C}$ por 10 minutos para extensão final e temperatura de manutenção de $4^{\circ} \mathrm{C}$ até a retirada do produto. 
PCR nested (n-PCR): segundo passo

No segundo passo, as reações de amplificação foram realizadas utilizando-se uma mistura com volume total de 50 $\mathrm{L}$ constituída de: tampão de

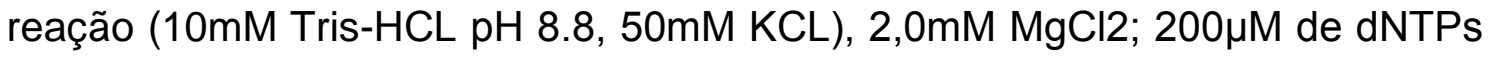
(dATP, dCTP, dGTP, dTTP); 0,4 $\mu \mathrm{M}$ de cada primer; $1 \mathrm{U}$ da enzima Taq DNA polimerase e $10 \mu \mathrm{L}$ do produto amplificado no primeiro passo (amplicom). Foram utilizados os primers internos F2 e R2 para amplificação do segundo produto de 194pb (Tabela 5).

O ciclo para amplificação consiste em uma desnaturação a 96ํㅡ por 3 minutos: a amplificação do produto foi realizada com uma sequência de 25 ciclos, cada um deles composto de $94^{\circ} \mathrm{C}$ por 30 segundos para desnaturação do DNA molde, $5^{\circ} \mathrm{C}$ a 30 segundos para a hibridização dos primers e $72^{\circ} \mathrm{C}$ a 1 minuto para a extensão das novas cadeias. Ao final dos ciclos segue-se um aquecimento a $72^{\circ} \mathrm{C}$ por 10 minutos para extensão final e temperatura de manutenção a $4^{\circ} \mathrm{C}$ até a retirada do produto.

Análise eletroforética dos produtos amplificados.

Os produtos de amplificação (PCR) e reamplificação (n-PCR) foram separados por eletroforese em gel de agarose a $2 \%$ fundida em tampão TBE (Tris-Borato-EDTA) acrescida de $0,5 \mu \mathrm{g} / \mathrm{mL}$ de brometo de etídeo (Sugden et al., 1975)

A corrida foi realizada a 120 volts por, aproximadamente, 1 hora e 30 minutos, em cuba horizontal, sendo aplicados $20 \mu \mathrm{L}$ da solução de reação acrescidas de $5 \mu \mathrm{L}$ de tampão de carregamento (Blue Juice: 0,3\% de azul de bromofenol, 65\%sacarose, 10mM Tris-HCL pH 7,5, 10mM EDTA) por caneleta do gel. O marcador 50bp DNA Ladder (BioLabs®) foi utilizado como padrão de massa molecular. Ao final da eletroforese os géis foram visualizados e documentados no programa Alphalmager EC (Alpha Innotech®), pelo sistema de captura de imagem (Alphalmager Software ${ }^{\circledR}$ ). As reações da PCR e n-PCR 
eram consideradas satisfatórias quando os controles positivos mostravam bandas bem definidas e não ocorriam bandas no controle negativo. Foram consideradas positivas todas as amostras que apresentaram bandas visíveis no gel de agarose com peso molecular correspondente ao tamanho do amplicom pesquisado e referenciado pelo padrão de peso molecular e controle positivo.

No estudo retrospectivo, não foi realizada a análise eletroforética dos produtos amplificados, uma vez que já se conheciam os resultados da fase prospectiva e a principal técnica a ser investigada no presente estudo era a nRT-PCR.

\section{PCR em tempo real (RT-PCR)}

As reações de RT-PCR foram realizadas empregando-se o sistema de sondas de hidrólise TaqMan® (Applied Biosystems), utilizando uma mistura com volume total de $25 \mu \mathrm{L}$ contendo: $12.5 \mu \mathrm{L}$ de $2 \mathrm{X}$ TaqMan ${ }^{\circledR} M a s t e r$ MixUniversal (Universal PCR Master Mix - Applied Biosystems), $5 \mu \mathrm{L}$ do DNA extraído, $300 \mathrm{nM}$ de cada primer e 100nM da sonda. Foram incluídos em cada reação dois poços de controle positivo (cepa H37RV) e quatro de controles sem DNA, e foram empregados na reação, para amplificação do DNA extraído diretamente da amostra, os iniciadores denominados de MyF e MyR, cujas sequências estão descritas na Tabela 5 .

Para a amplificação foi utilizado o ciclo universal do aparelho 7.300 Real Time PCR Systems (Applied Biosystems ${ }^{\circledR}$ ) composto por $50^{\circ} \mathrm{C}$ por 2 minutos (eliminação de contaminantes pela ação da Amperase-UNG), 95ํㅡ por 10 minutos (inativação da amperase, desnaturação do DNA molde, ativação da Taq polimerase), uma sequência de 45 ciclos, cada um deles consistindo em reações a $95^{\circ} \mathrm{C}$ por 15 segundos para desnaturação do DNA molde, $60^{\circ} \mathrm{C}$ por 1 minuto (anelamento e extensão das fitas). Os dados foram coletados na fase de extensão (60ํ $\mathrm{C}$ por 1 minuto). A análise dos dados foi realizada pelo 
software da máquina (7300 SDS Systems-Applied Biosystems ${ }^{\circledR}$ ). Foram consideradas positivas as amostras que apresentaram curva de amplificação (exponencial) e multicomponentes característicos além de Cycle threshold (Ct) $\leq 38$, que foi utilizado como valor limitante de positividade.

\section{PCR nested em tempo real (nRT-PCR)}

As reações de nRT-PCR foram realizadas empregando-se o sistema de sondas de hidrólise TaqMan® (Applied Biosystems), utilizando uma mistura com volume total de $25 \mu \mathrm{L}$ contendo: $12,5 \mu \mathrm{L}$ de $2 \mathrm{X}$ TaqMan ${ }^{\circledR} M a s t e r$ MixUniversal (Universal PCR Master Mix - Applied Biosystems), $5 \mu \mathrm{L}$ do produto amplificado no primeiro passo (amplicom) da PCR convencional, 300nM de cada iniciador (primer) e $100 \mathrm{nM}$ da sonda. Foram incluídos em cada reação dois poços de controle positivo (cepa H37RV) e quatro de controles sem DNA, e para a reamplificação do amplicom foram utilizados os iniciadores MyF e MyR (Tabela 5).

Para a amplificação foi utilizado o ciclo universal do aparelho 7.300 Real Time PCR Systems (Applied Biosystems ${ }^{\circledR}$ ) composto por $50^{\circ} \mathrm{C}$ por 2 minutos (eliminação de contaminantes pela ação da Amperase-UNG), 95ㄷ $\mathrm{C}$ por 10 minutos (inativação da amperase, desnaturação do DNA molde, ativação da Taq polimerase), uma sequencia de 45 ciclos, cada um deles consistindo em reações a $95^{\circ} \mathrm{C}$ por 15 segundos para desnaturação do DNA molde, $60^{\circ} \mathrm{C}$ por 1 minuto (anelamento e extensão das fitas). Os dados foram coletados na fase de extensão ( $60^{\circ} \mathrm{C}$ por 1 minuto). $A$ análise dos dados foi realizada pelo software da máquina (7300 SDS Systems-Applied Biosystems ${ }^{\circledR}$ ). Foram consideradas positivas as amostras que apresentaram curva de amplificação (exponencial) e multicomponentes característicos além de Cycle threshold (Ct) $\leq 20$, que foi utilizado como valor limitante de positividade. 
Uma reação de PCR em tempo real foi empregada para detectar a presença de ribonuclease humana (RNase) gene $\mathrm{P}$, descrito por Emery et al.(2004) em todas as amostras de LCR com a finalidade de monitorar a eficiência da extração do ácido nucleico. Este gene constitutivo é detectado em todas as amostras de origem humana e consequentemente indicam a presença de material humano suficiente para serem analisados por ensaios da PCR. A deteç̧ão deste alvo confirma como verdadeiro um resultado negativo e a ausência pode indicar a perda de DNA genômico humano durante o processo da extração ou a sua inexistência na amostra. Todas as amostras com resultado negativo para a RNaseP, foram retestadas para esse alvo. Esta reação foi realizada paralelamente e nas mesmas condições empregadas ao ensaio da nRT-PCR para a detecção de DNA de M. tuberculosis. 
Tabela 5 - Fragmentos do gene mpt64 do M. tuberculosis (GeneBank BX842578) e os locais de ligação dos iniciadores (primers) e da sonda (probe) utilizados

CTCGCGAGTCTAGGCCAGCATCGAGTCGATCGCGGAACGTGGGACCAATACCTGGGTTGG
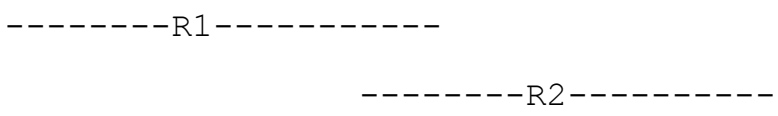

GCCGGCTGCTTCGGGCAGCAACTCCCCCGGGTTGAAGAAGAAAATCACCCCGTCGTTCGTG

ACTGCGAAGTTCTGATAATTCACCGGGTCCAAGCCGGCATTCGGCGCTATCGATACCTGTT

GTCCGGTCTGCTTGCTCAGTTCACCTTGCACAATGGGGAAGACGACTGGCAGCGGAT $-\mathrm{F}-$

As sequências de iniciadores e sondas de cada reação da PCR (Takahashi et al., 2006):

PCR convencional - 239pb

F1 ATC CGC TGC CAG TCG TCT TCC

R1 CTC GCG AGT CTA GGC CAG CAT

PCR convencional formato "nested" ( $n$-PCR) - 201pb

F2 CAT TGT GCA AGG TGA ACT GAG C

R2 AGC ATC GAG TCG ATC GCG GAA

PCR em tempo real (RT-PCR) - Fragmento de 77pb

F $\quad$ GTG AAC TGA GCA AGC AGA CCG

R GTT CTG ATA ATT CAC CGG GTC C

Probe FAM-TAT CGA TAG CGC CGA ATG CCG G-BHQ 


\subsection{Análise dos Dados}

Os dados coletados no estudo foram incorporados consecutivamente em um banco de dados eletrônico. Foi utilizada a estatística descritiva para apresentar os dados demográficos e clínicos da população estudada. Devido à possibilidade de comparação com estudos posteriores, optou-se por utilizar a classificação padronizada de Marais et al. (2010b) para descrever as características clínicas, radiológicas e laboratoriais dos pacientes categorizados.

Para comparação das variáveis categóricas entre as categorias diagnósticas, foi utilizado o teste exato de Fisher. A normalidade dos dados quantitativos foi verificada graficamente (normal quantile plot). As variáveis quantitativas com distribuição normal foram comparadas utilizando o teste ANOVA. Foram calculadas as médias e os desvios padrões ( $\pm D P$ ). Para variáveis sem distribuição normal, foi usado o teste Wilcoxon-Mann-Whitney para comparações entre duas categorias e o teste de Kruskal-Wallis para 3 ou mais categorias. Foram realizados cálculos de mediana, do primeiro e do terceiro quartil $\left(Q_{1 / 4}-Q_{3 / 4}\right)$. Foram utilizados diagramas de caixa (Box Plot) para ilustrar algumas tendências observadas na pontuação das categorias diagnósticas de MTB.

Foi realizado o cálculo de sensibilidade da nRT-PCR de acordo com o padrão-ouro (van Stralen et al., 2009), conforme fórmula descrita na Tabela 6. O padrão-ouro no diagnóstico de MTB foi definido como cultura de LCR positiva para M. tuberculosis e/ou observação de BAAR no contexto histológico compatível com TB do SNC (Thwaites et al., 2009; Marais et al., 2010b).

A especificidade foi calculada baseada nos pacientes com outros diagnósticos estabelecidos (categoria "Não MTB"). Foi calculado ainda o intervalo de confiança de 95\% (IC95\%) para os valores de sensibilidade e especificidade. Conforme descrito por Landis e Koch (1977), o índice Kappa (k) foi calculado e utilizado como indicador de concordância ajustada entre os resultados do padrão-ouro e da nRT-PCR. Quanto mais próximos de 1 forem 
os valores de $k$, melhor a concordância entre os testes. Valores de $k$ maiores que 0,81 são considerados ótimos, entre $0,61-0,80$ indicam boa concordância e entre 0,41 - 0,60 concordância regular (Landis; Koch, 1977).

Tabela 6 - Tabela para cálculo de sensibilidade e especificidade do teste quando comparados ao padrão-ouro

\begin{tabular}{lcc}
\hline & Padrão-ouro positivo & Padrão-ouro negativo \\
\hline nRT- PCR positiva & $a$ & $b$ \\
nRT- PCR negativa & $c$ & $d$ \\
\hline
\end{tabular}

Sensibilidade $=a /(a+c) ;$ Especificidade $=d /(b+d)$

Além do cálculo de sensibilidade e especificidade baseadas no padrãoouro e nos pacientes com diagnóstico alternativo distinto de MTB, também foi calculada a proporção de resultados positivos da nRT-PCR nas categorias diagnósticas definidas pelo presente estudo e nas categorias da padronização internacional (Marais et al., 2010b).

\subsection{Considerações Éticas}

Após esclarecimento do doente ou de seus representantes legais quanto à natureza da pesquisa, os pacientes que apresentavam critérios de inclusão foram convidados a participar do estudo. Manifestaram sua livre vontade em participar da pesquisa ao assinarem o termo de consentimento livre e esclarecido (TCLE: Anexo B). O estudo foi aprovado pelo Comitê de Ética em Pesquisa do IIER (Parecer: 310/2007), pelo Comitê de Ética em Pesquisa do CRT-DST/AIDS (Protocolo: 007-2011) e Sistema Gestão de Pesquisa HC-FMUSP (CAPPesq: 0151/11), conforme Anexo C. Para os casos incluídos na fase retrospectiva, o termo de confidencialidade foi devidamente preenchido e aprovado pelos Comitês de Ética em Pesquisa do IIER e CRTDST/AIDS. 
4. Resultados 


\subsection{Resultados do estudo prospectivo}

\section{Dados demográficos e clínicos}

Cento e dois pacientes internados no IIER foram incluídos. Setenta e quatro pacientes $(73 \%)$ eram do sexo masculino e a mediana de idade foi de 36 anos $(30-43)$.

Trinta e cinco pacientes tinham relato ou evidência de tuberculose prévia, sendo 21 deles (60\%) com forma pulmonar, seis (17\%) com TB em SNC (que já haviam completado tratamento há mais de 2 anos), cinco (14\%) com TB ganglionar e um paciente $(3 \%)$ com cada uma das formas a seguir: TB intestinal, TB hepática, TB disseminada. Vinte e três (23\%) pacientes faleceram e 0 restante teve alta hospitalar com melhora dos sintomas. A Tabela 7 apresenta os principais dados clínicos, laboratoriais e radiológicos dos pacientes, conforme categoria diagnóstica (Marais et al., 2010b) que foram alocados.

A prevalência de HIV na população estudada foi de 90\% (92 pacientes). Por causa da alta prevalência no estudo, foi realizada uma descrição separada das características desses pacientes na Tabela 8.

Não houve diferença significativa entre as categorias com relação à distribuição dos pacientes quanto ao sexo $(p=0,19)$, à idade $(p=0,83)$, à ocorrência TB prévia $(p=0,45)$ e à prevalência de HIV $(p=0,45)$. Também não houve diferença com relação ao $\mathrm{CD}_{4}$ (atual e nadir $[p=0,94$ e 0,95$]$ ) e dias de sintomas $(p=0,56)$.

Os sintomas mais prevalentes foram cefaleia (58\%) e confusão mental (40\%), não havendo diferença na distribuição dos sintomas entre as categorias diagnósticas $(p>0,10)$. 
Tabela 7 - Características principais dos pacientes conforme categoria diagnóstica padronizada de MTB

\begin{tabular}{|c|c|c|c|c|c|}
\hline $\begin{array}{r}\text { CATEGORIA MTB } \\
\mathrm{n} \\
\end{array}$ & $\begin{array}{r}\text { DEFINITIVA } \\
9 \\
\end{array}$ & $\begin{array}{r}\text { PROVÁVEL } \\
8 \\
\end{array}$ & $\begin{array}{r}\text { POSSÍVEL } \\
4 \\
\end{array}$ & $\begin{array}{r}\text { EXCLUÍDA } \\
81 \\
\end{array}$ & $\begin{array}{r}\text { TOTAL } \\
102 \\
\end{array}$ \\
\hline $\begin{array}{l}\text { SEXO Masculino (\%) } \\
\text { IDADE }^{1}\end{array}$ & $\begin{array}{r}7(78 \%) \\
32 \\
(28-43)\end{array}$ & $\begin{array}{r}6(75 \%) \\
33 \\
(31-43)\end{array}$ & $\begin{array}{r}1(25 \%) \\
36 \\
(33-43)\end{array}$ & $\begin{array}{r}60(74 \%) \\
37 \\
(30-43)\end{array}$ & $\begin{array}{r}75 \\
36 \\
(30-43)\end{array}$ \\
\hline TB PRÉVIA (\%) & $5(56 \%)$ & $3(38 \%)$ & $2(50 \%)$ & $25(31 \%)$ & $35(34 \%)$ \\
\hline $\begin{array}{l}\text { HIV positivo (\%) } \\
\text { CD4 atual }\left(\text { cél } / \mathrm{mm}^{3}\right)^{1}\end{array}$ & $\begin{array}{r}8(89 \%) \\
26 \\
(22-52)\end{array}$ & $\begin{array}{r}6(75 \%) \\
152 \\
(85-270)\end{array}$ & $\begin{array}{r}4(100 \%) \\
111 \\
(65-213)\end{array}$ & $\begin{array}{r}74(91 \%) \\
80 \\
(19-193)\end{array}$ & $\begin{array}{r}92(90 \%) \\
76 \\
(23-192)\end{array}$ \\
\hline CD4 nadir (cél $\left./ \mathrm{mm}^{3}\right)^{1}$ & $\begin{array}{r}17 \\
(17-52)\end{array}$ & $\begin{array}{r}106 \\
(41-268)\end{array}$ & $\begin{array}{r}87 \\
(40-155)\end{array}$ & $\begin{array}{r}46 \\
(14-112)\end{array}$ & $\begin{array}{r}46 \\
(17-130)\end{array}$ \\
\hline TEMPO DE SINTOMAS (dias) ${ }^{1}$ & $\begin{array}{r}30 \\
(15-30)\end{array}$ & $\begin{array}{r}40 \\
(26-68)\end{array}$ & $\begin{array}{r}25 \\
(18-38)\end{array}$ & $\begin{array}{r}15 \\
(4-30)\end{array}$ & $\begin{array}{r}17 \\
(4-30)\end{array}$ \\
\hline FEBRE (\%) & $3(33 \%)$ & 7 (88\%) & $2(50 \%)$ & $21(26 \%)$ & $33(32 \%)$ \\
\hline \multicolumn{6}{|l|}{ SINTOMAS PREVALENTES } \\
\hline * Cefaleia (\%) & $7(78 \%)$ & $3(38 \%)$ & $3(75 \%)$ & $46(57 \%)$ & $59(58 \%)$ \\
\hline * Confusão Mental (\%) & $8(89 \%)$ & $4(50 \%)$ & $3(75 \%)$ & $26(32 \%)$ & $41(40 \%)$ \\
\hline * Convulsão (\%) & 0 & $1(13 \%)$ & 0 & $10(12 \%)$ & $11(11 \%)$ \\
\hline * Paralisia nervo craniano (\%) & 0 & 0 & $1(25 \%)$ & $16(20 \%)$ & $17(17 \%)$ \\
\hline SINAIS MENÍNGEOS (\%) & $2(22 \%)$ & $1(13 \%)$ & 0 & $10(12 \%)$ & $13(13 \%)$ \\
\hline E.C. GLASGOW ${ }^{1}$ & $\begin{array}{r}14 \\
(10-14)\end{array}$ & $\begin{array}{r}15 \\
(14-15)\end{array}$ & $\begin{array}{r}15 \\
(15-15)\end{array}$ & $\begin{array}{r}15 \\
(15-15)\end{array}$ & $\begin{array}{r}15 \\
(14-15)\end{array}$ \\
\hline BMRC ( I / II / III) & $(1 / 4 / 4)$ & $(3 / 5 / 0)$ & $(1 / 3 / 0)$ & $(39$ / 39 / 3) & $(44 / 51 / 7)$ \\
\hline Hemoglobina $(\mathrm{g} / \mathrm{dL})^{2}$ & $9,7( \pm 1,2)$ & $10,1( \pm 1,8)$ & $12,4( \pm 3,1)$ & $11,4( \pm 2,3)$ & $10,9( \pm 2,3)$ \\
\hline Sódio sérico $(\mathrm{mEq} / \mathrm{L})^{2}$ & $135( \pm 6,2)$ & $133( \pm 8,2)$ & $132( \pm 3,1)$ & $135( \pm 6,3)$ & $135( \pm 6,3)$ \\
\hline о́вIто & $4(44 \%)$ & $2(25 \%)$ & 0 & $17(21 \%)$ & $23(23 \%)$ \\
\hline \multicolumn{6}{|l|}{ PARÂMETROS DO LCR } \\
\hline${ }^{*}$ Leucócitos $\left(\text { cél } / \mathrm{mm}^{3}\right)^{1}$ & $\begin{array}{r}75 \\
(37-176)\end{array}$ & $\begin{array}{r}101 \\
(54-135)\end{array}$ & $\begin{array}{r}38 \\
(30-248)\end{array}$ & $\begin{array}{r}5 \\
(2-40)\end{array}$ & $\begin{array}{r}14 \\
(2-75)\end{array}$ \\
\hline${ }^{*}$ Neutrófilos (\% leucócitos) ${ }^{1}$ & $\begin{array}{r}48 \\
(20-68)\end{array}$ & $\begin{array}{r}13 \\
(1-42)\end{array}$ & $\begin{array}{r}3 \\
(1-16)\end{array}$ & $\begin{array}{r}0 \\
(0-3)\end{array}$ & $\begin{array}{r}1 \\
(0-9)\end{array}$ \\
\hline${ }^{\star}$ Linfócitos (\% leucócitos) ${ }^{1}$ & $\begin{array}{r}21 \\
(15-40)\end{array}$ & $\begin{array}{r}66 \\
(38-79)\end{array}$ & $\begin{array}{r}85 \\
(70-89)\end{array}$ & $\begin{array}{r}33 \\
(0-89)\end{array}$ & $\begin{array}{r}42 \\
(0-88)\end{array}$ \\
\hline${ }^{*}$ Proteína $(\mathrm{mg} / \mathrm{dL}){ }^{1}$ & $\begin{array}{r}193 \\
(171-400)\end{array}$ & & & & $\begin{array}{r}87 \\
(48-176)\end{array}$ \\
\hline${ }^{\star}$ Glicose $(\mathrm{mg} / \mathrm{dL})^{1}$ & $\begin{array}{r}21 \\
(17-29)\end{array}$ & $\begin{array}{r}41 \\
(36-47)\end{array}$ & $\begin{array}{r}33 \\
(27-37)\end{array}$ & $\begin{array}{r}50 \\
(43-60)\end{array}$ & $\begin{array}{r}47 \\
(36-58)\end{array}$ \\
\hline${ }^{\star}$ Razão Glicose (LCR/soro) ${ }^{1}$ & $\begin{array}{r}0,21 \\
(, 15-, 39)\end{array}$ & $\begin{array}{r}0,32 \\
(, 31-, 42)\end{array}$ & $\begin{array}{r}0,41 \\
(, 34-, 43)\end{array}$ & $\begin{array}{r}0,53 \\
(, 38-, 63)\end{array}$ & $\begin{array}{r}0,49 \\
(, 35-, 62)\end{array}$ \\
\hline${ }^{\star} \mathrm{ADA}(\mathrm{UI} / \mathrm{L}){ }^{1}$ & $\begin{array}{r}3,5 \\
(2,7-7)\end{array}$ & $\begin{array}{r}7,2 \\
(5,9-7,9)\end{array}$ & $\begin{array}{r}6,5 \\
(5,5-8,8)\end{array}$ & $\begin{array}{r}3,3 \\
(0,6-8,5)\end{array}$ & $\begin{array}{r}3,9 \\
(1-8,4)\end{array}$ \\
\hline \multicolumn{6}{|l|}{ TOMOGRAFIA DE CRÂNIO } \\
\hline${ }^{*}$ Atrofia cortical (\%) & $5(56 \%)$ & $4(50 \%)$ & $3(75 \%)$ & $43(53 \%)$ & $55(54 \%)$ \\
\hline * Lesão focal (\%) & $1(11 \%)$ & $3(38 \%)$ & $1(25 \%)$ & $31(38 \%)$ & $36(35 \%)$ \\
\hline${ }^{*}$ Hidrocefalia & $3(33 \%)$ & $3(38 \%)$ & $1(25 \%)$ & $7(09 \%)$ & $14(14 \%)$ \\
\hline * Hiperdensidade basal(\%) & $2(22 \%)$ & $1(13 \%)$ & 0 & $3(08 \%)$ & $6(06 \%)$ \\
\hline * Infarto cerebral (\%) & $1(11 \%)$ & $3(38 \%)$ & 0 & $2(3 \%)$ & $6(06 \%)$ \\
\hline Pontuação critério Marais ${ }^{1}$ & $\begin{array}{r}14,2 \\
(13-15)\end{array}$ & $\begin{array}{r}14,5 \\
(14-15)\end{array}$ & $\begin{array}{r}9,5 \\
(9-10)\end{array}$ & $\begin{array}{r}7,3 \\
(6-9)\end{array}$ & $\begin{array}{r}8,5 \\
(6-11)\end{array}$ \\
\hline
\end{tabular}


Tabela 8 - Características principais dos pacientes infectados por HIV conforme categoria diagnóstica padronizada de MTB

\begin{tabular}{|c|c|c|c|c|c|}
\hline $\begin{array}{r}\text { CATEGORIA MTB } \\
\mathrm{n} \\
\end{array}$ & $\begin{array}{r}\text { DEFINITIVA } \\
8 \\
\end{array}$ & $\begin{array}{r}\text { PROVÁVEL } \\
6 \\
\end{array}$ & $\begin{array}{r}\text { POSSIVEL } \\
4 \\
\end{array}$ & $\begin{array}{r}\text { EXCLUÍDA } \\
74 \\
\end{array}$ & $\begin{array}{c}\text { TOTAL } \\
92\end{array}$ \\
\hline $\begin{array}{l}\text { SEXO Masculino (\%) } \\
\text { IDADE }^{1}\end{array}$ & $\begin{array}{r}6(75 \%) \\
32.5 \\
(28-44)\end{array}$ & $\begin{array}{r}5(83 \%) \\
38 \\
(32-46)\end{array}$ & $\begin{array}{r}1(25 \%) \\
36 \\
(33-43)\end{array}$ & $\begin{array}{r}54(73 \%) \\
37 \\
(30-43)\end{array}$ & $\begin{array}{r}65(71 \%) \\
37 \\
(31-43)\end{array}$ \\
\hline TB PRÉVIA (\%) & $5(63 \%)$ & $3(50 \%)$ & $2(50 \%)$ & $25(34 \%)$ & $35(38 \%)$ \\
\hline USO PRÉVIO DE TARV (\%) & $4(50 \%)$ & $3(50 \%)$ & $3(75 \%)$ & $40(54 \%)$ & 50 (54\%) \\
\hline CD4 atual $\left(\text { cél } / \mathrm{mm}^{3}\right)^{1}$ & $\begin{array}{r}26 \\
(22-52)\end{array}$ & $\begin{array}{r}152 \\
(85-270)\end{array}$ & $\begin{array}{r}111 \\
(65-213)\end{array}$ & $\begin{array}{r}79 \\
(19-190)\end{array}$ & $\begin{array}{r}73 \\
(23-189)\end{array}$ \\
\hline CD4 nadir (cél $\left./ \mathrm{mm}^{3}\right)^{1}$ & & & $\begin{array}{r}87 \\
(40-155)\end{array}$ & $\begin{array}{r}46 \\
(14-112)\end{array}$ & $\begin{array}{r}46 \\
(17-130)\end{array}$ \\
\hline TEMPO DE SINTOMAS (dias) ${ }^{1}$ & $\begin{array}{r}30 \\
(15-30)\end{array}$ & $\begin{array}{r}40 \\
(33-55)\end{array}$ & $\begin{array}{r}25 \\
(18-38)\end{array}$ & $\begin{array}{r}15 \\
(4-30)\end{array}$ & $\begin{array}{r}20 \\
(5-30)\end{array}$ \\
\hline FEBRE (\%) & $3(38 \%)$ & $5(83 \%)$ & $2(50 \%)$ & $18(24 \%)$ & $27(29 \%)$ \\
\hline \multicolumn{6}{|l|}{ SINTOMAS PREVALENTES } \\
\hline${ }^{*}$ Cefaleia (\%) & $6(75 \%)$ & $2(33 \%)$ & $3(75 \%)$ & $40(54 \%)$ & $51(55 \%)$ \\
\hline * Confusão Mental (\%) & 7 (88\%) & $3(50 \%)$ & $3(75 \%)$ & $23(31 \%)$ & 36 (39\%) \\
\hline * Convulsão (\%) & 0 & $1(17 \%)$ & 0 & $9(12 \%)$ & $10(11 \%)$ \\
\hline${ }^{*}$ Paralisia nervo craniano (\%) & 0 & 0 & $1(25 \%)$ & $16(22 \%)$ & 17 (19\%) \\
\hline $\begin{array}{l}\text { SINAIS MENÍNGEOS (\%) } \\
\text { E.C. GLASGOW }{ }^{1}\end{array}$ & $\begin{array}{r}1(13 \%) \\
14 \\
(12-14)\end{array}$ & $\begin{array}{r}0 \\
14 \\
(14-15)\end{array}$ & $\begin{array}{r}0 \\
14 \\
(14-14)\end{array}$ & $\begin{array}{r}9(12 \%) \\
14 \\
(14-15)\end{array}$ & $\begin{array}{r}10(11 \%) \\
14 \\
(14-15)\end{array}$ \\
\hline BMRC ( I / II / III) & $(1 / 4 / 3)$ & $(2 / 4 / 0)$ & $(1 / 3 / 0)$ & $(37 / 35 / 2)$ & $(41 / 46 / 5)$ \\
\hline Hemoglobina $(\mathrm{g} / \mathrm{dL})^{2}$ & $9,7( \pm 1,3)$ & $9,8( \pm 1,5)$ & $12,4(3,1)$ & $11,0( \pm 2,2)$ & $10,9( \pm 2,1)$ \\
\hline Sódio sérico $(\mathrm{mEq} / \mathrm{L})^{2}$ & $135( \pm 6,3)$ & $135( \pm 9,0)$ & $132( \pm 3,1)$ & $135( \pm 6,1)$ & $135( \pm 6,2)$ \\
\hline о́вIто & $3(38 \%)$ & $2(33 \%)$ & 0 & $16(22 \%)$ & 21 (23\%) \\
\hline \multicolumn{6}{|l|}{ PARÂMETROS LIQUÓRICOS } \\
\hline${ }^{*}$ Leucócitos $\left(\text { cél } / \mathrm{mm}^{3}\right)^{1}$ & $\begin{array}{r}78 \\
(43-211)\end{array}$ & $\begin{array}{r}101 \\
(52-120)\end{array}$ & $\begin{array}{r}38 \\
(30-248)\end{array}$ & $\begin{array}{r}6 \\
(1-45)\end{array}$ & $\begin{array}{r}16 \\
(2-78)\end{array}$ \\
\hline${ }^{*}$ Neutrófilos (\% leucócitos) ${ }^{1}$ & $\begin{array}{r}49 \\
(25-70)\end{array}$ & $\begin{array}{r}19 \\
(3-34)\end{array}$ & $\begin{array}{r}15 \\
(1-16)\end{array}$ & $\begin{array}{r}0 \\
(0-3)\end{array}$ & $\begin{array}{r}1 \\
(0-10)\end{array}$ \\
\hline${ }^{*}$ Linfócitos (\% leucócitos) ${ }^{1}$ & $\begin{array}{r}30 \\
(19-54)\end{array}$ & $\begin{array}{r}66 \\
(45-77)\end{array}$ & & $\begin{array}{r}32 \\
(0-88)\end{array}$ & $\begin{array}{r}42 \\
(0-88)\end{array}$ \\
\hline${ }^{\star}$ Proteína $(\mathrm{mg} / \mathrm{dL})^{1}$ & $\begin{array}{r}187 \\
(157-306)\end{array}$ & $\begin{array}{r}98 \\
(82-110)\end{array}$ & $\begin{array}{r}187 \\
(176-196)\end{array}$ & $\begin{array}{r}71 \\
(42-148)\end{array}$ & $\begin{array}{r}85 \\
(50-178)\end{array}$ \\
\hline${ }^{\star}$ Glicose $(\mathrm{mg} / \mathrm{dL})^{1}$ & & & & & \\
\hline${ }^{*}$ Razão Glicose (LCR/soro) ${ }^{1}$ & $\begin{array}{r}0,23 \\
(, 18-, 39)\end{array}$ & $\begin{array}{r}0,32 \\
(, 31-, 38)\end{array}$ & $\begin{array}{r}0,41 \\
(, 34-, 43)\end{array}$ & $\begin{array}{r}0,51 \\
(, 37-, 63)\end{array}$ & $\begin{array}{r}0,48 \\
(, 35-, 60)\end{array}$ \\
\hline${ }^{*} \mathrm{ADA}(\mathrm{UI} / \mathrm{L})^{1}$ & $\begin{array}{r}3,1 \\
(2,7-3,8)\end{array}$ & & & $\begin{array}{r}3,3 \\
(0,6-8,8)\end{array}$ & $\begin{array}{r}3,9 \\
(1,1-8,1)\end{array}$ \\
\hline \multicolumn{6}{|l|}{ TOMOGRAFIA DE CRÂNIO } \\
\hline${ }^{*}$ Atrofia cortical (\%) & $5(63 \%)$ & $4(67 \%)$ & $3(75 \%)$ & $41(55 \%)$ & $53(58 \%)$ \\
\hline${ }^{*}$ Lesão focal (\%) & $1(13 \%)$ & $3(50 \%)$ & $1(25 \%)$ & $30(41 \%)$ & 35 (38\%) \\
\hline * Hidrocefalia & $2(25 \%)$ & $2(33 \%)$ & $1(25 \%)$ & $6(8 \%)$ & $11(12 \%)$ \\
\hline${ }^{*}$ Hiperdensidade basal (\%) & $2(25 \%)$ & 0 & 0 & $3(4 \%)$ & $5(5 \%)$ \\
\hline * Infarto cerebral (\%) & $1(13 \%)$ & $3(50 \%)$ & 0 & $1 \quad(1 \%)$ & 5 ( $5 \%)$ \\
\hline Pontuação critério Marais ${ }^{2}$ & $\begin{array}{r}14,5 \\
(14-15) \\
\end{array}$ & $\begin{array}{r}14,5 \\
(14-15) \\
\end{array}$ & $\begin{array}{r}9,5 \\
(9-10)\end{array}$ & $\begin{array}{r}8,0 \\
(6-9)\end{array}$ & $\begin{array}{r}8,0 \\
(7-10)\end{array}$ \\
\hline
\end{tabular}


Classificação dos pacientes nas categorias diagnósticas

Conforme os critérios propostos pelo presente estudo a partir da revisão da literatura, os 102 pacientes foram classificados nas categorias expostas na Tabela 9.

Tabela 9 - Classificação dos pacientes nas categorias diagnósticas propostas a partir da revisão da literatura

\begin{tabular}{lrr}
\hline Categorias diagnósticas & Frequência & Porcentagem \\
\hline MTB DEFINITIVA & 9 & $8.8 \%$ \\
MTB PROVÁVEL & 6 & $5.9 \%$ \\
MTB POSSÍVEL & 6 & $5.9 \%$ \\
NÃO MTB & 81 & $78.4 \%$ \\
TOTAL & $\mathbf{1 0 2}$ & $\mathbf{1 0 0 . 0 \%}$ \\
\hline
\end{tabular}

Os pacientes também foram classificados em categorias conforme a padronização internacional proposta por Marais et al. (2010b). De acordo com os critérios da Tabela 4, os 102 pacientes incluídos receberam uma pontuação específica que permitiu sua classificação inicial em uma das categorias propostas. Quando os resultados dos exames mais conclusivos se tornaram disponíveis os pacientes foram alocados nas categorias diagnósticas finais, conforme ilustrado na Figura 2. Todos os pacientes não categorizados inicialmente, isto é, com pontuação no escore diagnóstico menor que 6 , foram posteriormente alocados na categoria "Não MTB", pois tiveram outros diagnósticos etiológicos estabelecidos. 


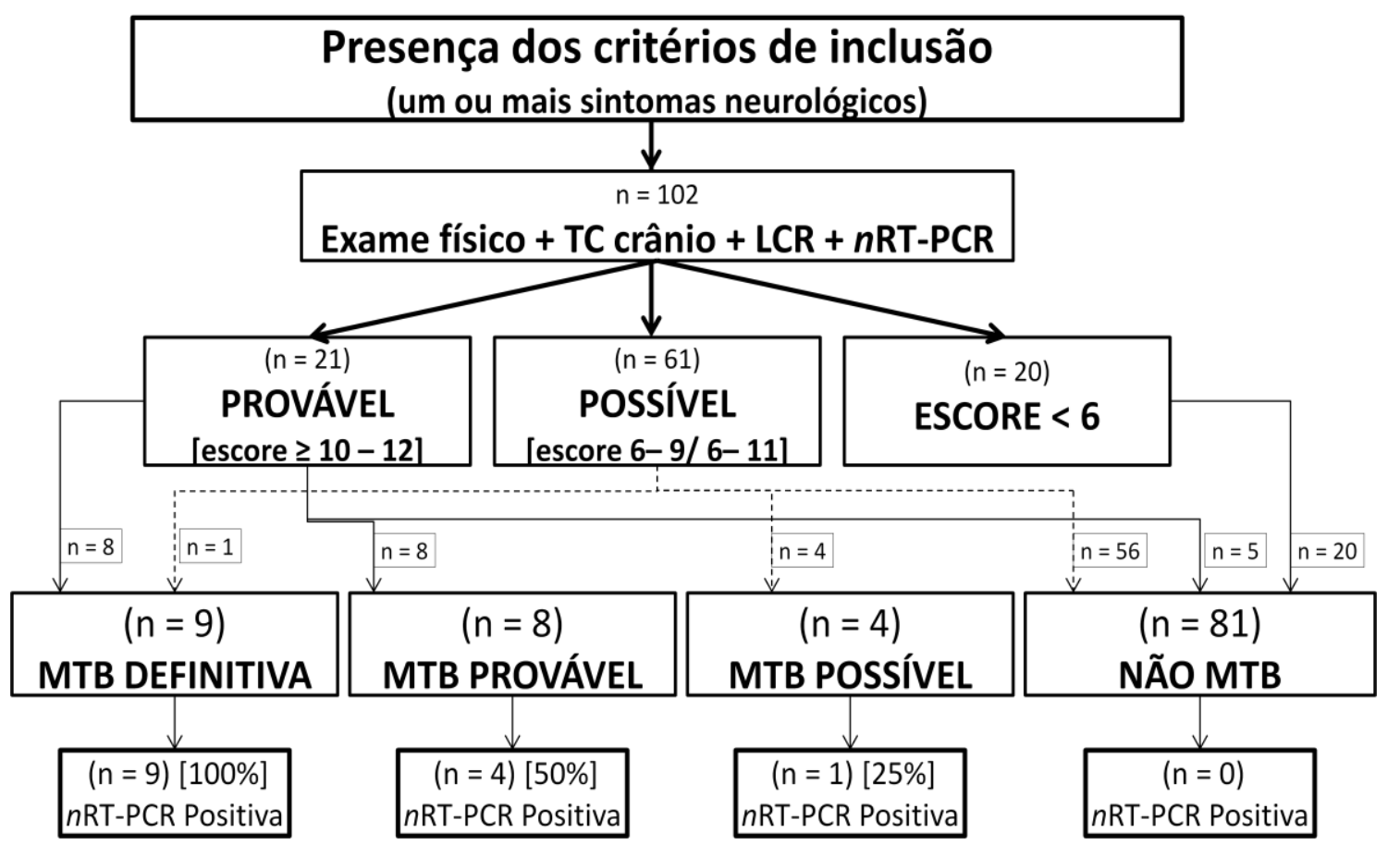

102 pacientes foram incluídos no estudo prospectivo. Cada um deles recebeu uma pontuação inicial, conforme os critérios de Marais et al.(2010b). Esse escore permitiu categorizar inicialmente 21 sujeitos na categoria "MTB Provável" e 61 na categoria "MTB Possível". 20 pacientes receberam escore menor que 6 e não foram inicialmente incluídos nas categorias. Conforme resultados de exames mais conclusivos se tornaram disponíveis os pacientes foram alocados na categoria diagnóstica final: nove pacientes na categoria "MTB Definitiva", oito na "MTB Provável", quatro na "MTB Possível" e 81 na categoria "Não MTB". Os quadros inferiores do fluxograma revelam os dados de positividade da nRTPCR nas categorias diagnósticas.

Figura 2 - Fluxograma do estudo com classificação inicial e final dos pacientes conforme as categorias diagnósticas padronizadas

Observou-se que a classificação dos pacientes nas categorias propostas a partir da revisão da literatura foi muito semelhante à classificação final dos pacientes nas categorias diagnósticas propostas por Marais et al. (2010b). As categorias "MTB Definitiva" e "Não MTB" foram idênticas em número e compostas pelos mesmos pacientes.

Dois pacientes classificados como "MTB Possível" segundo a categorização proposta a partir da revisão da literatura, foram classificados como "MTB Provável" pelos critérios de Marais et al. (2010b). Eles apresentavam alterações radiológicas que lhes conferiram alta pontuação nos critérios de Marais et al. (2010b) e os levou a serem classificados como "MTB Provável”. No entanto, não apresentavam BAAR isolado fora do SNC.

Portanto, de acordo com os critérios propostos a partir de revisão de 
literatura (Figura 1), foram classificados como "MTB Possível”, diferindo da categorização de Marais et al. (2010b). Os demais pacientes classificados como "MTB Provável" e "MTB Possível" eram idênticos em ambas as categorizações.

O Gráfico 4 ilustra uma tendência na pontuação dos pacientes das diferentes categorias, conforme os critérios de Marais et al. (2010b). Observase que os pacientes da categoria "MTB Provável" apresentaram pontuação similar aos classificados como "MTB Definitiva", enquanto os pacientes classificados como "MTB Possível" apresentam pontuação similar aos da categoria "Não MTB".

Gráfico 4 - Box Plot mostrando a diferença de pontuação final entre as categorias diagnósticas padronizadas dos pacientes

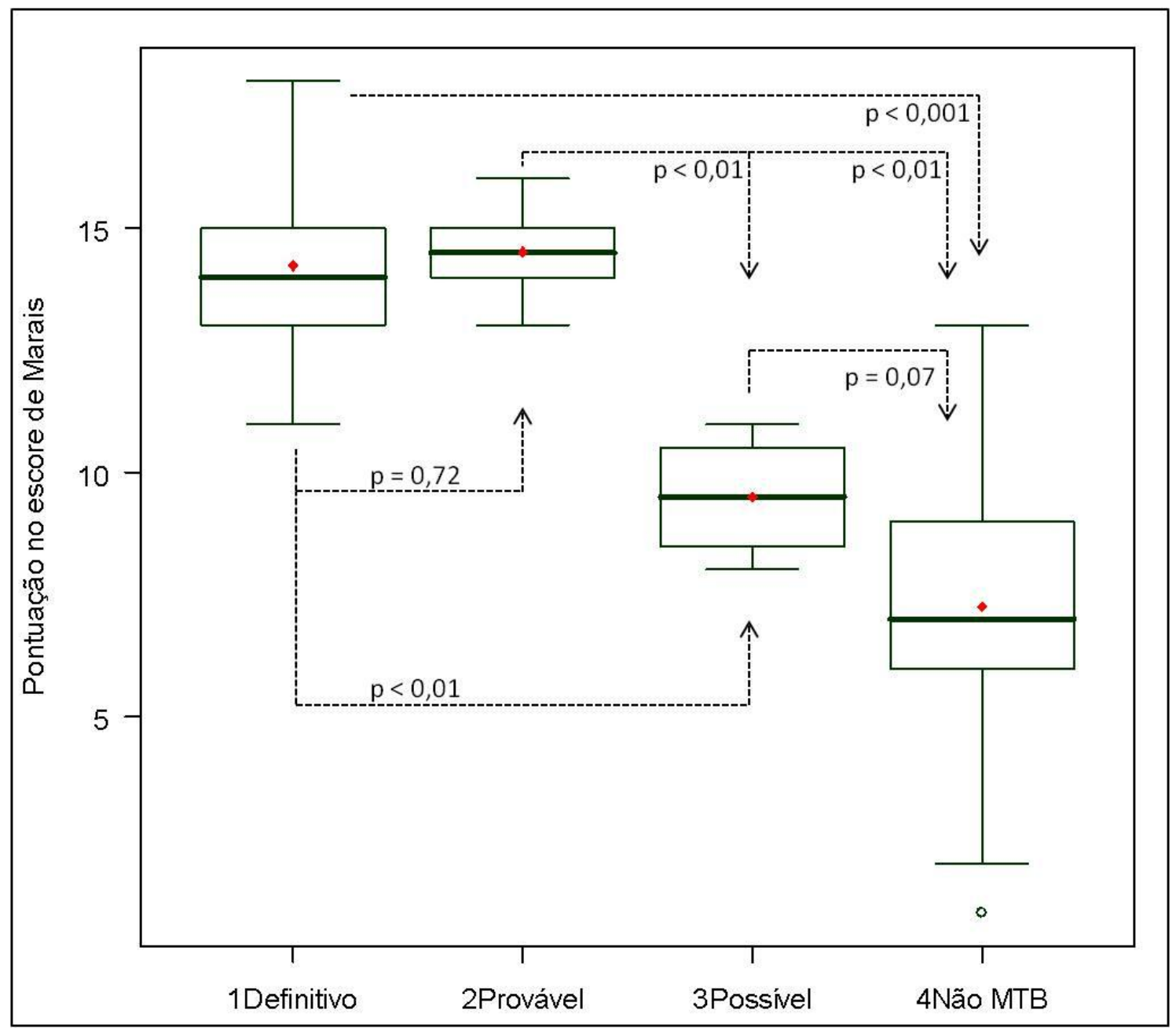

Nota: Não houve diferenças entre categorias "MTB Definitiva" e "MTB Provável" $(p=0,72)$ e entre "MTB Possível" e “Não MTB" $(p=0,07)$. Houve diferença entre "MTB Definitiva" e "Não MTB" $(p<0,001)$, entre "MTB Definitiva" e "MTB Possível" $(p<0,01)$, entre "MTB Provável" e “MTB Possível" $(p<0,01)$ e entre "MTB Provável" e "Não MTB" $(p<0,01)$. 
Todos os 21 pacientes das categorias com suspeita de MTB (Definitiva, Provável e Possível) foram tratados com tuberculostáticos, conforme as práticas de rotina da instituição (IIER). Dois pacientes da categoria "MTB Possível" também foram tratados por 14 dias com Ceftriaxona devido suspeita não confirmada de meningite bacteriana. Quinze, entre os 21 pacientes tratados com terapia anti-tuberculosa, apresentaram melhora clínica e tiveram alta hospitalar. Os outros seis pacientes faleceram, sendo 4 deles da categoria "MTB Definitiva" e dois da "MTB Provável". Não ocorreram óbitos na categoria "MTB Possível". Na categoria "Não MTB" ocorreram 17 óbitos por complicações relacionadas ao quadro clínico.

\section{TC de crânio}

Entre os pacientes da categoria "MTB Definitiva", três apresentaram hidrocefalia e dois tiveram hiperdensidade meníngea basal. Também foi observada uma lesão focal em região fronto-temporal esquerda com edema perilesional em um paciente e uma imagem sugestiva de isquemia de troco cerebral em outro indivíduo. Quatro pacientes da categoria "MTB Definitiva" não apresentaram lesões sugestivas de MTB: dois deles apenas com atrofia cortical e dois sem quaisquer alterações na TC de crânio.

Entre aqueles categorizados como "MTB Provável", hidrocefalia, lesão focal e imagem sugestiva de isquemia foram encontradas em três pacientes. Um deles apresentou realce meníngeo basal e dois pacientes não tiveram lesões sugestivas de MTB. Na categoria "MTB Possível", um paciente apresentou lesão focal e hidrocefalia. Os outros pacientes não tiveram lesões sugestivas de MTB.

Entre os indivíduos da categoria "Não MTB", imagens sugestivas de toxoplasmose do SNC (opacidades anelares com captação de contraste, edema e efeito de massa em áreas núcleo-capsulares) foram encontradas em 15 pacientes, que tiveram boa resposta à terapêutica específica para essa doença. Entre os doentes com diagnóstico de meningite criptocóccica, o 
achado mais frequente $(46,6 \%)$ foi de atrofia cortical. A distribuição das alterações encontradas na TC de crânio está citada nas Tabelas 7 e 8.

\section{Dados laboratoriais dos agentes infecciosos identificados}

Entre os nove indivíduos da categoria "MTB Definitiva", a cultura foi positiva para $M$. tuberculosis no LCR de oito pacientes (7\%). Foi identificada resistência em três amostras de $M$. tuberculosis isolados do LCR: em dois pacientes a cepa era resistente à rifampicina e à isoniazida e em outro paciente apenas à isoniazida.

BAAR foi identificado no SNC de dois pacientes: um deles no LCR (também apresentava cultura positiva no LCR para M. tuberculosis). O outro BAAR foi identificado no SNC (necropsia), num contexto histológico compatível com TB (necrose caseosa em cisternas basais), mas a cultura desse paciente no LCR foi negativa.

Foi encontrado BAAR no escarro de 12 pacientes e em tecido linfonodal de três pacientes. Em todos os pacientes com BAAR no escarro, o M. tuberculosis foi identificado na cultura. Entre aqueles com BAAR no linfonodo, M. tuberculosis foi identificado em dois pacientes e no outro foi identificado Mycobacterium avium complex.

Treze (13\%) pacientes tiveram cultura positiva para Cryptococcus sp., e um paciente para $N$. meningitidis, Oitenta $(78 \%)$ culturas de LCR foram negativas para bactérias, fungos e micobactérias. O látex para Cryptococcus $s p$. e a tinta da china foram positivos em 14 (13\%) pacientes. A mediana de contagem de fungos no exame micológico direto foi de 37,5 leveduras ( 3 210).

Entre os 50 pacientes nos quais o LCR foi submetido à PCR para outros agentes infecciosos, a PCR foi positiva para toxoplasmose em quatro pacientes, para JC vírus e Citomegalovírus (CMV) em um paciente. O VDRL foi 
positivo no LCR de um paciente.

Entre os pacientes na categoria "Não MTB", o diagnóstico alternativo mais frequente foi a toxoplasmose do SNC (16) e a meningite criptocóccica (15). Nove pacientes foram diagnosticados com sepse: em sete deles o microorganismo foi isolado em hemocultura e os outros dois tiveram boa resposta ao tratamento exclusivo com antibióticos de largo espectro (Imipenem e Vancomicina). Os outros diagnósticos estão descritos na Tabela 10.

Tabela 10 - Diagnósticos dos pacientes incluídos na categoria "Não MTB"

\begin{tabular}{lrr}
\hline Diagnóstico Final & Frequência & Porcentagem \\
\hline Toxoplasmose do SNC & 16 & $19,5 \%$ \\
Meningoencefalite Criptocóccica & 15 & $18,3 \%$ \\
Encefalite por CMV & 9 & $11,0 \%$ \\
Sepse com delirium & 9 & $11,0 \%$ \\
Encefalopatia por HIV & 6 & $6,1 \%$ \\
Neurossífilis & 4 & $4,9 \%$ \\
Linfoma do SNC & 3 & $3,7 \%$ \\
Enxaqueca & 3 & $3,7 \%$ \\
LEMP & 2 & $2,5 \%$ \\
MAC disseminado & 2 & $2,5 \%$ \\
Acidente vascular cerebral isquêmico & 2 & $2,5 \%$ \\
Abandono do tratamento de epilepsia & 2 & $2,5 \%$ \\
Meningite viral & 1 & $2,5 \%$ \\
Encefalomielite aguda disseminada & 1 & $1,2 \%$ \\
Cefaleia pós-punção & 1 & $1,2 \%$ \\
Encefalopatia hepática & 1 & $1,2 \%$ \\
Esquistossomose medular & 1 & $1,2 \%$ \\
Lúpus Eritematoso Sistêmico & 1 & $1,2 \%$ \\
Meningite por Neisseria meningitidis & 1 & $1,2 \%$ \\
Uremia & 1 & $1,2 \%$ \\
\hline TOTAL & $\mathbf{1 0 0 . 0 \%}$ \\
\hline Nota: SNC: Sistema Nervoso Central
\end{tabular}

Nota: SNC: Sistema Nervoso Central / CMV: Citomegalovírus / LEMP: Leucoencefalopatia multifocal progressiva / MAC: Mycobacterium avium complex

Três pacientes tiveram $M$. tuberculosis isolado em hemocultura. Demais micro-organismos isolados em hemocultura estão listados abaixo, na Tabela 11. 
Tabela 11 - Micro-organismos isolados em hemoculturas dos pacientes

\begin{tabular}{lrr}
\hline Resultado hemocultura & Frequência & Porcentagem \\
\hline Cryptococcus spp. & 7 & $6.9 \%$ \\
M. tuberculosis & 3 & $2.9 \%$ \\
S. epidermides & 2 & $2.0 \%$ \\
Acinetobacter baumani & 1 & $1.0 \%$ \\
S. aureus & 1 & $1.0 \%$ \\
Salmonela sp. & 1 & $1.0 \%$ \\
Serratia marcescens & 1 & $1.0 \%$ \\
Staphylococcus saprophyticus & 1 & $1.0 \%$ \\
Negativa & 80 & $78.4 \%$ \\
Não Realizada & 5 & $4.9 \%$ \\
\hline TOTAL & $\mathbf{1 0 2}$ & $\mathbf{1 0 0 . 0} \%$ \\
\hline
\end{tabular}

Resultados das técnicas da reação em cadeia da polimerase

Quatorze (14\%) amostras de LCR tiveram a n-PCR e a nRT-PCR positivas para M. tuberculosis. Como os resultados desses dois métodos foram idênticos, os resultados adiante farão referência apenas à nRT-PCR, que foi a principal metodologia investigada. A PCR convencional e a PCR em tempo real realizada diretamente no LCR não apresentaram resultados positivos entre as amostras analisadas.

A nRT-PCR foi positiva em todas as amostras com padrão-ouro positivo. A nRT-PCR foi negativa em todas as amostras de líquor de pacientes com outros diagnósticos clínicos definidos ("Não MTB"). O tempo entre a coleta do exame de LCR e o resultado da PCR foi de aproximadamente 24 horas, sendo o tempo do processamento laboratorial da amostra de 6 horas.

A Figura 3 demonstra um exemplo de resultado de uma amostra positiva da $\mathrm{nRT}$-PCR. 


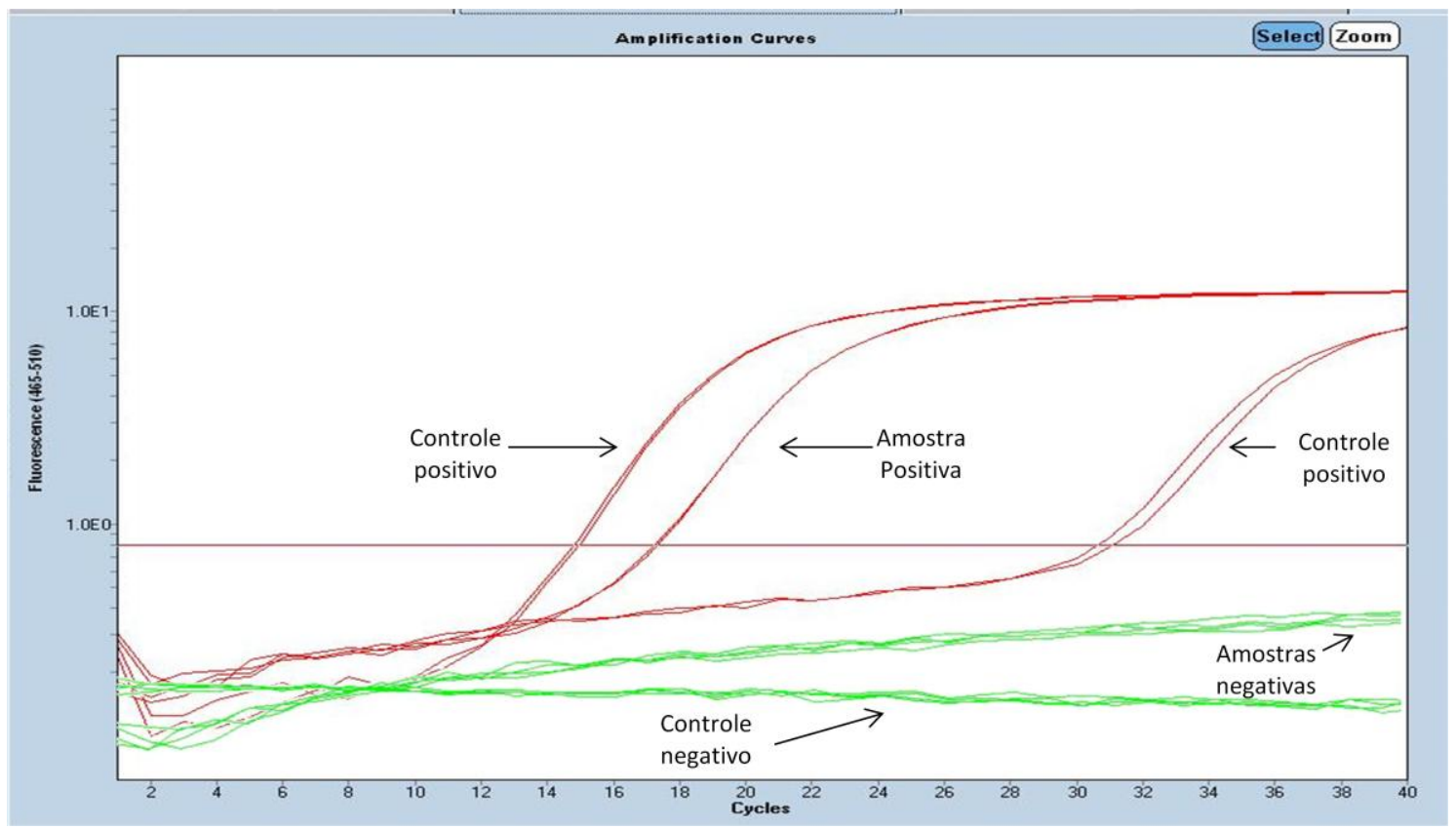

Nota: A figura demonstra um exemplo de resultados obtidos no ensaio da nRT-PCR onde verifica-se curvas de amplificação obtidas em função do ciclo $x$ emissão de fluorescência, que ultrapassaram a linha limítrofe (threshold) entre reações positivas (vermelho) e negativas (verdes). Foram consideradas positivas as amostras que apresentaram curva de amplificação (exponencial) e multicomponentes característicos com um Cycle threshold $(C t) \leq 20$. Na figura há uma amostra positiva, com um $C t$ de 17 e controles positivos com $C t$ de 15 e 31 .

Figura 3 - Exemplo representativo do resultado da reação da nRT-PCR

A Tabela 12 mostra a distribuição dos pacientes nas categorias diagnósticas propostas a partir da revisão da literatura, conforme o resultado da nRT-PCR. Ela também inclui o padrão-ouro (categoria "MTB Definitiva") para a qual foi calculada sensibilidade e especificidade.

Tabela 12 - Distribuição dos pacientes nas categorias diagnósticas propostas a partir da revisão da literatura e resultado da nRT-PCR, com dados de sensibilidade, especificidade e intervalos de confiança [IC95\%]

\begin{tabular}{|c|c|c|c|c|c|}
\hline \multirow[b]{2}{*}{ nRT-PCR } & \multicolumn{4}{|c|}{ Categorias Diagnósticas de MTB } & \multirow[b]{2}{*}{ TOTAL } \\
\hline & DEFINITIVA & PROVÁVEL & POSSÍVEL & NÃO MTB & \\
\hline $\begin{array}{l}\text { Positiva } \\
\text { Sensibilidade } \\
\text { IC } 95 \%\end{array}$ & $\begin{array}{r}9 \\
100 \% \\
{[70-100]}\end{array}$ & $\begin{array}{r}4 \\
66,7 \% \\
{[30-90,3]}\end{array}$ & $\begin{array}{r}1 \\
16,8 \% \\
{[3-56,4]}\end{array}$ & $\begin{array}{l}0 \\
- \\
-\end{array}$ & 14 \\
\hline $\begin{array}{l}\text { Negativa } \\
\text { Sensibilidade } \\
\text { IC 95\% }\end{array}$ & $\begin{array}{l}0 \\
- \\
-\end{array}$ & $\begin{array}{l}2 \\
- \\
- \\
\end{array}$ & $\begin{array}{l}5 \\
- \\
- \\
\end{array}$ & $\begin{array}{r}81 \\
100 \% \\
{[95,4-100]}\end{array}$ & $\begin{array}{r}88 \\
- \\
-\end{array}$ \\
\hline TOTAL & 9 & 6 & 6 & 81 & 102 \\
\hline
\end{tabular}

Nota: Kappa = 1 
Quando somados os casos que tiveram BAAR isolado em qualquer sítio ("MTB Definitiva" + "MTB Provável"), observou-se que 87\% (13 entre os 15 pacientes) tiveram a nRT-PCR positiva.

A Tabela 13 mostra a distribuição final dos pacientes segundo as categorias propostas por Marais et al. (2010b), conforme o resultado da nRTPCR.

Tabela 13 - Distribuição dos pacientes nas categorias diagnósticas padronizadas e resultado da nRT-PCR, com dados de sensibilidade, especificidade e intervalos de confiança [IC95\%]

\begin{tabular}{lrrrrr}
\hline \multicolumn{5}{c}{ Categorias Diagnósticas de MTB } \\
\hline$n$ RT-PCR & DEFINITIVA & PROVÁVEL & POSSÍVEL & NÃO MTB & TOTAL \\
\hline Positiva & 9 & 4 & 1 & 0 & 14 \\
Sensibilidade & $100 \%$ & $50 \%$ & $25 \% \%$ & - & - \\
IC 95\% & {$[70-100]$} & {$[21,5-78,5]$} & {$[4,6-70]$} & - & - \\
Negativa & 0 & 4 & - & $100 \%$ & - \\
Especificidade & - & - & - & {$[95,4-100]$} & - \\
IC 95\% & - & - & 4 & 81 & 102 \\
\hline TOTAL & 9 & 8 & & 38 \\
\hline
\end{tabular}

Nota: Kappa $=1$

$\mathrm{Na}$ Tabela 14, encontra-se a distribuição final dos pacientes HIV positivos segundo as categorias propostas por Marais et al. (2010b), conforme o resultado da $\mathrm{nRT}$-PCR.

Tabela 14 - Distribuição dos pacientes HIV positivos nas categorias diagnósticas padronizadas e resultado da nRT-PCR, com dados de sensibilidade, especificidade e intervalos de confiança [IC95\%]

\begin{tabular}{|c|c|c|c|c|c|}
\hline \multicolumn{6}{|c|}{ Categorias Diagnósticas de MTB } \\
\hline$n R T-P C R$ & DEFINITIVA & PROVÁVEL & POSSÍVEL & NÃO MTB & TOTAL \\
\hline $\begin{array}{l}\text { Positiva } \\
\text { Sensibilidade } \\
\text { IC 95\% }\end{array}$ & $\begin{array}{r}8 \\
100 \% \\
{[67-100]}\end{array}$ & $\begin{array}{r}4 \\
66,7 \% \\
{[30-90]}\end{array}$ & $\begin{array}{r}1 \\
25 \% \\
{[4,6-70]}\end{array}$ & $\begin{array}{l}0 \\
- \\
-\end{array}$ & $\begin{array}{r}13 \\
- \\
-\end{array}$ \\
\hline $\begin{array}{l}\text { Negativa } \\
\text { Especificidade } \\
\text { IC } 95 \%\end{array}$ & $\begin{array}{l}0 \\
- \\
-\end{array}$ & $\begin{array}{l}2 \\
- \\
-\end{array}$ & $\begin{array}{l}3 \\
- \\
-\end{array}$ & $\begin{array}{r}74 \\
100 \% \\
{[95-100]}\end{array}$ & $\begin{array}{r}79 \\
- \\
-\end{array}$ \\
\hline TOTAL & 8 & 6 & 4 & 74 & 92 \\
\hline
\end{tabular}

Nota: Kappa = 1 


\subsection{Resultados do estudo retrospectivo}

Pacientes incluídos e dados clínicos

Cento e cinquenta pacientes tiveram a nRT-PCR solicitada, sendo 65 deles do CRT DST/AIDS e 85 do IIER. A maioria dos pacientes foi excluída do estudo por falta de dados clínicos necessários para categorização diagnóstica ou por falta de dados laboratoriais necessários para acessar o diagnóstico definitivo (p. ex.: culturas de líquor e sangue, exames de imagem, sorologia).

Entre os pacientes com dados clínicos completos, 58 pacientes preencheram os critérios de inclusão, mas dois pacientes foram excluídos porque a quantidade de líquor enviado para a nRT-PCR foi inferior a $500 \mu \mathrm{L}$, o que inviabilizou a realização do teste.

Entre os 56 pacientes incluídos nessa fase 22 eram do CRT DST/AIDS e 26 do IIER. A mediana de idade foi de 40 anos (32 - 46). Trinta e seis (64\%) pacientes eram do sexo masculino.

Dezoito pacientes (32\%) tinham relato ou evidência de tuberculose prévia, sendo dez deles com a forma pulmonar e dois com a forma ganglionar. Os outros seis pacientes não tinham registro de qual forma de TB tiveram. A prevalência de HIV na população estudada foi de $86 \%$ (48 pacientes).

Assim como no estudo prospectivo, os sintomas mais prevalentes na população estudada foram a cefaleia (54\%) e a confusão mental (39\%). A mediana de CD4 dos 45 pacientes que tiveram esse exame coletado no momento da internação foi de 107 células $/ \mathrm{mm}^{3}$ (21 - 225). Oito pacientes (15\%) tinham carga viral (CV) menor que 50 cópias e quatro tinham CV acima do limite de detecção (> 750.000 cópias). Entre aqueles com CV entre cinquenta e 750.000 (32 sujeitos), a mediana de CV foi de 38.889 cópias virais $(77-447.570)$.

Oito pacientes (14\%) faleceram e o restante teve alta hospitalar com melhora dos sintomas. Entre os pacientes que faleceram, três eram da 
categoria "MTB Definitiva" e dois da categoria "MTB Provável".

Classificação dos pacientes do estudo retrospectivo nas categorias diagnósticas

De acordo com os dados coletados dos sujeitos incluídos no estudo e seguindo os critérios descritos na secção de métodos, 56 pacientes foram divididos nas categorias diagnósticas. Inicialmente, cinco pacientes haviam sido classificados na categoria "MTB Provável", mas com o resultado da cultura positiva no LCR, um deles foi realocado na categoria "MTB Definitiva". Oito pacientes foram classificados inicialmente como "MTB Possível", cinco deles migraram para a categoria "MTB Definitiva" após o resultado da cultura de micobactéria no LCR e 1 para categoria "MTB Provável", após resultado positivo de cultura de tecido linfonodal. A distribuição final dos pacientes nas categorias diagnósticas propostas a partir da revisão da literatura está na Tabela 15.

Tabela 15 - Classificação dos pacientes do estudo retrospectivo nas categorias diagnósticas propostas a partir da revisão da literatura

\begin{tabular}{lrr}
\hline Categorias diagnósticas & Frequência & Porcentagem \\
\hline MTB DEFINITIVA & 6 & $\mathbf{1 1} \%$ \\
MTB PROVAVEL & 5 & $9 \%$ \\
MTB POSSIVEL & 0 & $0 \%$ \\
NÃO MTB & 45 & $80 \%$ \\
\hline TOTAL & $\mathbf{5 6}$ & $\mathbf{1 0 0 . 0 \%}$ \\
\hline
\end{tabular}

Assim como realizado com os pacientes do estudo prospectivo, todos os 56 pacientes incluídos no estudo retrospectivo também receberam uma pontuação específica que permitiu sua classificação nas categorias propostas por Marais et al. (2010b), conforme ilustrado na Figura 4. 


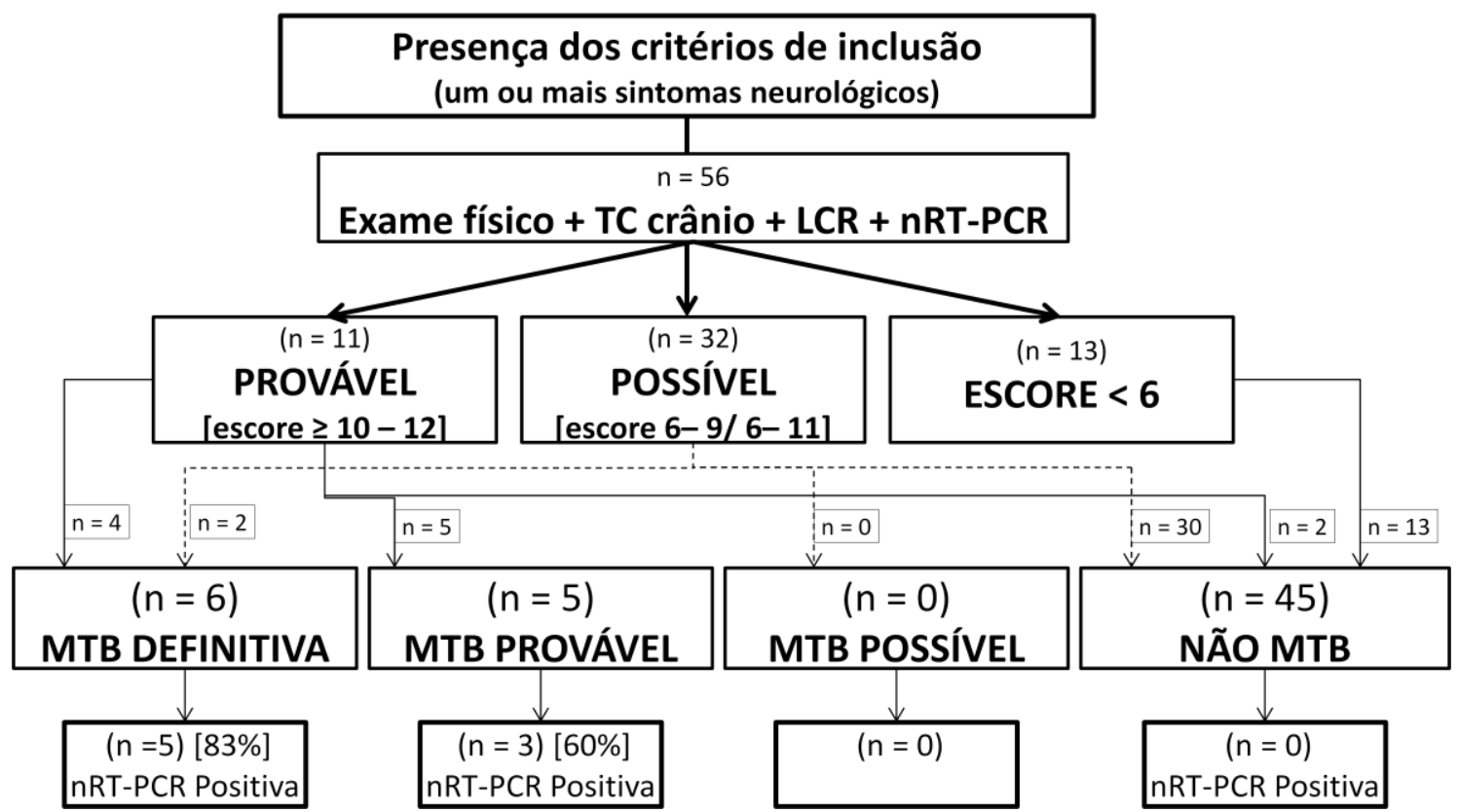

56 pacientes foram incluídos no estudo retrospectivo. Cada um deles recebeu uma pontuação inicial. Esse escore permitiu categorizar inicialmente 11 sujeitos na categoria "MTB Provável" e 32 na "MTB Possível". As linhas tracejadas mostram a migração dos pacientes entre as categorias diagnósticas conforme resultados de exames mais conclusivos, estabelecendo a classificação final: seis pacientes na categoria "MTB Definitiva", cinco na "MTB Provável", nenhum na "MTB Possível" e 45 na "Não MTB". Treze pacientes receberam escore menor que 6 e não foram inicialmente incluídos nas categorias. Posteriormente esses pacientes tiveram diagnósticos alternativos estabelecidos e alocados na categoria "Não MTB".

Figura 4 - Classificação inicial e final dos pacientes conforme as categorias diagnósticas padronizadas

Observou-se que a classificação dos pacientes nas categorias propostas a partir da revisão da literatura foi idêntica à classificação final dos pacientes nas categorias diagnósticas propostas por Marais et al. (2010b) no estudo retrospectivo.

TC de crânio

Entre os seis pacientes da categoria "MTB Definitiva", dois apresentaram lesões focais, um apresentou hidrocefalia grave e em outro foi observada imagem tálamo-capsular esquerda sugestiva de isquemia. Um paciente dessa categoria não apresentou alterações na TC de crânio. Os resultados da TC de crânio não estavam anotados no prontuário de dois pacientes. 
Entre os cinco pacientes da categoria "MTB Provável", dois pacientes apresentaram lesões sugestivas de isquemia, sendo que em um deles também foi observada hidrocefalia. Três pacientes dessa categoria não apresentaram alterações na TC de crânio.

Entre os 45 indivíduos da categoria "Não MTB", 13 apresentaram lesões focais, quatro delas com realce após contraste, que foram associadas com diagnóstico de toxoplamose do SNC. Dois pacientes com LEMP apresentaram lesões hipodensas subcorticais em lobos frontal e temporal.

Dados laboratoriais dos agentes infecciosos identificados

A cultura foi positiva para M. tuberculosis no líquor de seis pacientes (11\%) da categoria "MTB Definitiva". Em uma paciente, o BAAR também foi positivo na baciloscopia de LCR. Na categoria "MTB Provável", BAAR foi identificado na baciloscopia de escarro de três pacientes e em biópsia de linfonodos de outros dois.

Oito pacientes (15\%) tiveram cultura positiva para Cryptococcus sp., e uma paciente para $N$. meningitidis. As demais culturas de LCR foram negativas para bactérias, fungos e micobactérias. Dois pacientes tiveram o VDRL positivo no LCR.

Entre os pacientes na categoria "Não MTB", o diagnóstico mais frequente foi de toxoplasmose do SNC (13) e meningite criptocóccica (8). Os outros diagnósticos estão descritos na tabela 16. 
Tabela 16 - Diagnósticos dos pacientes incluídos na categoria "Não MTB" no estudo retrospectivo

\begin{tabular}{lrr}
\hline Diagnóstico final & Frequência & Porcentagem \\
\hline Toxoplasmose do SNC & 13 & $24 \%$ \\
Meningoencefalite criptocóccica & 8 & $15 \%$ \\
Encefalopatia por HIV & 6 & $11 \%$ \\
Baixa adesão ao tratamento de epilepsia & 4 & $7 \%$ \\
Enxaqueca & 2 & $4 \%$ \\
LEMP & 2 & $4 \%$ \\
Neurossífilis & 2 & $4 \%$ \\
Meningoencefalite herpética & 2 & $4 \%$ \\
Sepse com delirium & 2 & $4 \%$ \\
Linfoma do sistema nervoso central & 1 & $2 \%$ \\
Meningite por Neisseria meningitidis & 1 & $2 \%$ \\
Mielopatia associada ao HTLV-1 & 1 & $2 \%$ \\
Doença de Still & 1 & $\mathbf{2} \%$ \\
\hline TOTAL & $\mathbf{4 5}$ & $\mathbf{1 0 0 . 0} \%$ \\
\hline
\end{tabular}

Nota: SNC: Sistema Nervoso Central / LEMP: Leucoencefalopatia multifocal progressiva

Foi isolado M. tuberculosis fora do SNC em oito pacientes (14\%), sendo cinco no escarro, um em gânglio inguinal e outro em abscesso do músculo psoas.

Resultados da $n R T-P C R$ no estudo retrospectivo

Conforme descrito nos métodos do estudo retrospectivo, apenas a nRT-PCR foi realizada nas amostras de LCR coletadas, porque na fase prospectiva essa foi a técnica que se mostrou mais eficaz, com menor tempo de processamento laboratorial e menor custo.

Entre as 58 amostras enviadas para análise, duas amostras foram excluídas, pois apresentavam volume menor que $1 \mathrm{~mL}$, o que prejudicaria 0 desempenho do teste. No mínimo $1 \mathrm{~mL}$ é necessário para a realização da nRTPCR. Esses pacientes foram excluídos da análise.

Entre as 56 amostras restantes, a nRT-PCR foi positiva em oito 
amostras. A distribuição das amostras positivas entre as categorias diagnósticas encontram-se na Tabela 17. Essa tabela inclui o padrão-ouro (categoria "MTB Definitiva") para a qual é calculada sensibilidade e especificidade.

Tabela 17 - Distribuição dos pacientes nas categorias diagnósticas padronizadas e resultado da nRT-PCR na fase retrospectiva, com dados de sensibilidade, especificidade e intervalos de confiança [IC95\%]

\begin{tabular}{lrrrrr}
\hline \multicolumn{5}{c}{ Categorias Diagnósticas de MTB } \\
\hline nRT-PCR & DEFINITIVA & PROVAVEL & POSSIVEL & NÃO MTB & TOTAL \\
Positiva & 5 & 3 & 0 & 0 & 8 \\
Sensibilidade & $83 \%$ & $60 \%$ & - & - & - \\
IC 95\% & {$[44-97]$} & {$[23-88]$} & - & - & - \\
Negativa & 1 & 2 & 0 & 45 & 48 \\
Especificidade & - & - & - & $100 \%$ & - \\
IC 95\% & - & - & - & {$[92-100]$} & - \\
\hline TOTAL & 6 & 5 & 0 & 45 & 56 \\
\hline Nota: Kappa $=0,89$ & & & & &
\end{tabular}

$\mathrm{Na}$ Tabela 18, encontra-se a distribuição final dos pacientes HIV positivos segundo as categorias diagnósticas padronizadas (Marais et al., 2010b), conforme o resultado da nRT-PCR.

Tabela 18 - Distribuição dos pacientes HIV positivos nas categorias diagnósticas padronizadas e resultado da nRT-PCR, com dados de sensibilidade, especificidade $e$ intervalos de confiança [IC95\%]

\begin{tabular}{lrrrrr}
\hline \multicolumn{5}{c}{ Categorias Diagnósticas de MTB } \\
\hline nRT-PCR & DEFINITIVA & PROVAVEL & POSSIVEL & NÃO MTB & TOTAL \\
Positiva & 3 & 3 & 0 & 0 & 6 \\
Sensibilidade & $75 \%$ & $60 \%$ & - & - & - \\
IC 95\% & {$[30-95]$} & {$[23-88]$} & - & - & - \\
Negativa & & - & - & 39 & 42 \\
Especificidade & - & - & - & {$[91-100]$} & - \\
IC 95\% & - & - & 0 & 39 & 48 \\
\hline TOTAL & 4 & 5 & & & \\
\hline
\end{tabular}

Nota: Kappa $=0,87$

Considerando a soma dos pacientes com padrão-ouro positivo no estudo prospectivo $(n=9)$ e no estudo retrospectivo $(n=6)$, a sensibilidade da nRT-PCR foi de 93\% (IC95\%: 70 - 98), com 14 das 15 amostras positivas $(k=0,94)$. 
5. Discussão 
A TB é um problema clínico e socioeconômico importante em todo mundo e no Brasil (WHO, 2013), particularmente em São Paulo (CVE/SP, 2013). A MTB - apresentação mais grave e letal da TB - continua a ser um importante problema de saúde pública, especialmente pela dificuldade associada ao seu diagnóstico oportuno (Thwaites et al., 2013). Por esse motivo, é fundamental avaliar técnicas diagnósticas alternativas (Marais et al., 2010b).

O Ministério da Saúde (MS) estabeleceu como uma das prioridades para o controle de TB em 2013 a ampliação do diagnóstico. O Programa Nacional de Controle de TB (PNCT) também tem desenvolvido ações com objetivo de ampliar o acesso ao diagnóstico e tratamento precoce, por ser essa uma importante estratégia para redução da morbimortalidade por TB (Brasil, 2013). Nesse contexto, pode-se inserir também a importância da avaliação de novas metodologias para o diagnóstico de MTB, como a nRT-PCR avaliada no presente estudo.

Esse estudo mostrou que a nRT-PCR é uma ferramenta útil e oportuna na investigação diagnóstica de pacientes com suspeita de MTB. No estudo prospectivo, observou-se uma sensibilidade e especificidade de $100 \%$ quando foram comparados os pacientes com padrão-ouro positivo e aqueles com outros diagnósticos estabelecidos. No estudo retrospectivo - fase operacional do trabalho mais próxima da prática clínica - a nRT-PCR teve uma sensibilidade de $83 \%$ e manteve a especificidade de $100 \%$. Em ambas as fases do estudo a nRT-PCR apresentou resultados confiáveis e alto grau de concordância com o padrão-ouro (k > 0,81).

O uso da nRT-PCR diminuiu o tempo necessário para um resultado confirmatório de MTB, com um tempo aproximado entre a coleta do LCR e a disponibilidade do resultado de 24 horas. Isso possibilitou o diagnóstico oportuno de pacientes com MTB que só teriam um resultado definitivo pelo padrão-ouro 2 a 4 semanas depois, caso a cultura fosse positiva (Venkataswamy et al., 2007; Marais et al., 2010a; Thwaites et al., 2013). Observou-se também uma menor complexidade para a realização do exame 
em situações de rotina, conforme relatado por outros autores (Takahashi et al., 2006, 2012).

Foi realizada uma categorização clínica de todos os pacientes incluídos no estudo para maior abrangência na determinação do desempenho da nRTPCR, conforme realizado previamente por outros autores (Ahuja et al., 1994; Kox et al., 1995; Kumar et al., 1999; Thwaites et al., 2002, 2009; Torok et al., 2008). Os ótimos resultados de sensibilidade e especificidade da nRT-PCR quando comparados ao padrão-ouro sugerem que os casos das categorias "MTB Provável" e "MTB Possível" com a nRT-PCR positiva tinham o diagnóstico de MTB, apesar da cultura negativa.

O número de indivíduos avaliados prospectivamente e submetidos à nRT-PCR foi de 102, com um número maior de pacientes infectados por HIV $(\mathrm{n}=92)$ que estudos prévios com técnicas similares (Folgueira et al., 1994; Scarpellini et al., 1995). O estudo retrospectivo incluiu 56 indivíduos - número menor que o do estudo prospectivo - porque muitas variáveis clínicas e laboratoriais não puderam ser recuperadas dos prontuários, o que excluiu cerca de $60 \%$ dos pacientes da análise.

A realização de duas fases do estudo permitiu a avaliação do valor diagnóstico da nRT-PCR em duas situações distintas: i. no estudo prospectivo, com todas as vantagens relacionadas ao maior rigor metodológico e a desvantagem da sua dispendiosa execução; ii. no estudo retrospectivo, com a vantagem de refletir melhor as situações de rotina do teste em mais de um centro de pesquisa, mas com a desvantagem do menor controle experimental. Dentro dessa perspectiva, julga-se que foi importante ter realizado as duas fases do estudo pelos ganhos que cada uma apresentou na avaliação da nRTPCR. Além disso, possibilitou aumentar o número de pacientes com diagnóstico definitivo de MTB. 


\subsection{Estudo prospectivo}

Entre os nove pacientes com padrão-ouro positivo, a nRT-PCR foi positiva em todos os casos. Todos os pacientes do estudo com outros diagnósticos definidos apresentaram resultado negativo da nRT-PCR, conferindo uma especificidade de 100\% [IC95\%: 95,4 - 100]. Esses achados são superiores à maioria dos estudos de técnicas da PCR que utilizaram a cultura como padrão-ouro no diagnóstico (Ahuja et al., 1994; Bonington et al., 2000; Caws et al, 2000; al., 2011; Martins et al., 2000; Narayanan et al., 2001; Bhigjee et al., 2007), nos quais as sensibilidades variaram entre $50-94 \%$. Os resultados da nRT-PCR também foram superiores à sensibilidade média de $56 \%$ encontrada em uma meta-análise prévia que avaliou ensaios comerciais da PCR em pacientes com suspeita de MTB (Pai et al., 2003).

Apesar do objetivo principal do estudo não ser a avaliação da PCR convencional e da RT-PCR realizadas diretamente na amostra clínica, também fizemos essa avaliação secundária no estudo prospectivo. Como era esperado, essas metodologias apresentaram resultados piores que as técnicas da PCR na qual o alvo genético (mpt64) foi reamplificado ( $n$-PCR e nRT-PCR) (Liu et al., 1994; Takahashi et al., 2005). A técnica da n-PCR apresentou resultado idêntico à nRT-PCR, no entanto sua execução é mais complexa, demorada e dispendiosa, tornando a nRT-PCR a técnica mais adequada para condições de rotina em um laboratório público (Takahashi et al., 2012).

Scarpellini et al. (1995) encontraram 100\% sensibilidade utilizando uma técnica de n-PCR entre 10 pacientes com cultura positiva no LCR, entretanto o número de pacientes com outras diagnósticos estabelecidos foi menor que 0 presente estudo. Rafi et al. (2007) também encontraram 100\% de sensibilidade, entretanto seu teste apresentou resultados falso-positivos, com uma especificidade de $89 \%$. Um estudo nacional prévio (Brienze et al., 2001) com 91 pacientes com suspeita de MTB utilizou uma técnica de n-PCR semelhante e obteve uma sensibilidade menor (53\%) nos 15 casos com confirmação microbiológica de MTB. 
Considerando o ótimo desempenho da nRT-PCR entre casos confirmados de MTB, pode-se aventar algumas variáveis técnicas para justificar a alta sensibilidade que foi observada: $i$. centrifugação das amostras e utilização do precipitado, como realizado em outro trabalho recente que também obteve bons resultados (Patel et al., 2013); ii. utilização de um método de extração de DNA mais eficiente (Takur et al., 2011), com maior lise da complexa parede celular micobacteriana através da lisozima e mutanolisina (Demerdash, 2012); iii. inclusão de controles internos em todas as reações da PCR, com demonstração de controles positivos com baixo Ct (nRT-PCR) em todas as amostras, sugerindo que não havia elementos inibidores da enzima Taq polimerase (Kirschner et al, 1996; Stauffer et al., 1998); iv. combinação da boa sensibilidade da técnica de reamplificação do DNA (nested PCR) (Scarpellini et al., 1995; Rafi et al., 2007; Huang et al., 2009) com a PCR em tempo real (Takahashi, 2012; Patel et al., 2013); v. observação direta e objetiva do processo de amplificação do DNA através da técnica em tempo real, reduzindo a possibilidade de variabilidade na leitura dos resultados, quando comparados à PCR convencional e à n-PCR (Takahashi et al., 2005, 2012).

Também foi observada uma alta especificidade no presente estudo, como habitualmente é relatado na literatura em meta-análises e revisões sobre as técnicas da PCR (Pai et al, 2003; Dinnes et al., 2007; Thwaites et al., 2013). Não houve amostras positivas da nRT-PCR entre os pacientes com outros diagnósticos clínicos estabelecidos. Antes do início do estudo com amostras clínicas de LCR, a nRT-PCR foi testada em 540 cepas bacterianas, incluindo 265 de micobactérias, sendo negativa em todas as amostras exceto naquelas do complexo M. tuberculosis [Gonçalves, MG. Comunicação pessoal]. Esses dados de especificidade obtidos nessas cepas foram corroborados no presente estudo com amostras clínicas de LCR.

Entre os fatores responsáveis pela alta especificidade observada, destacam-se as medidas de precaução para evitar contaminação, como uso de salas diferentes para os diversos passos da reação: a PCR convencional era realizada em sala diferente do local da n-PCR, que também era distinta da sala da nRT-PCR. Outro aspecto importante foi o fato do Laboratório de Meningites 
Bacterianas do IAL não processar amostras de escarro, que habitualmente apresentam alta carga bacilar, com potencial para contaminar todas as etapas dos ensaios da PCR (Shankar et al., 1991; Lee et al., 1994).

Alguns trabalhos avaliaram o desempenho da PCR em populações compostas predominantemente por pacientes infectados por HIV (Folgueira et al., 1994; Scarpellini et al., 1995; Bhigjee et al., 2007; Patel et al., 2013). Entre aqueles com a cultura positiva para $M$. tuberculosis no LCR, a PCR teve resultados de sensibilidade superiores aos dos pacientes sem HIV (Patel et al., 2013). Katrak et al., (2000) encontraram maior quantidade BAAR no parênquima cerebral e meninges de pacientes infectados por HIV quando comparados àqueles sem HIV. Apesar da quantidade de pacientes sem HIV ser pequena no estudo $(n=10), 13$ entre os 14 indivíduos com a nRT-PCR positiva eram infectados por HIV. Isso poderia corroborar a hipótese de que portadores do HIV teriam uma carga bacilar maior no LCR quando comparados aos não infectados (Dube et al., 1992; Thwaites et al., 2005; Puccioni-Sohler; Brandão, 2007; Torok et al., 2008), favorecendo um melhor desempenho da PCR nessa população (Patel et al., 2013).

De acordo com a Padronização para Comunicação de Acurácia Diagnóstica (STARD, do inglês Standards for Reporting of Diagnostic Accuracy), o padrão-ouro para a comparação de novos métodos diagnósticos não é necessariamente apenas um teste (Bossuyt et al., 2003). Um novo teste é mais bem avaliado quando estudado no contexto de uma estratégia diagnóstica, como parte de um pacote de testes (van Stralen et al., 2009; Schunemann et al., 2008). O padrão-ouro pode ser considerado uma combinação de métodos para estabelecer a presença de uma condição alvo. Pode incluir variáveis clínicas, exames de laboratório e imagem (Bossuyt et al, 2003; van Stralen et al., 2009). Optou-se por utilizar esse conceito no presente estudo, ao se criar uma categorização diagnóstica dos pacientes incluídos baseada nos critérios previamente publicados (Ahuja et al., 1994; Kox et al., 1995; Kumar et al., 1999; Thwaites et al., 2002, 2009; Torok et al., 2008). Isso possibilitou maior abrangência na determinação do valor diagnóstico da técnica da nRT-PCR, incluindo diversos cenários da prática clínica diária. 
Outros fatores que justificaram a escolha por categorizar os pacientes incluem a baixa sensibilidade do padrão-ouro (Naughten et al., 1981; Traub et al., 1984; Ogawa et al., 1987; Kent et al., 1993), a dificuldade em obter casuística confirmada por cultura em estudo prospectivo e a hipótese que a nRT-PCR poderia ser mais sensível que a cultura (Valenstein, 1990; Rafi et al., 2007, Takahashi et al., 2012). A opção por categorizar os doentes enriqueceu os resultados do estudo, uma vez que permitiu investigar indivíduos com padrão-ouro negativo e sem outros diagnósticos estabelecidos. Esses pacientes são um dilema enfrentado tanto na prática clínica quanto na pesquisa de novos métodos diagnósticos de MTB.

Durante a realização do presente estudo, um grupo de pesquisadores propôs uma padronização internacional de critérios e categorias para serem utilizados na investigação de MTB (Marais et al., 2010b), reforçando a opção de comparar os resultados de desempenho das técnicas diagnósticas com categorias e não apenas com o padrão-ouro. Os dados necessários para inclusão dos pacientes, assim como o preenchimento dos critérios do escore diagnóstico propostos por esses pesquisadores, tinham sido contemplados no desenho inicial do presente estudo. Isso permitiu que também se utilizasse essa padronização para a análise do valor diagnóstico da nRT-PCR. As vantagens do uso dessa classificação internacional resumem-se na reprodutibilidade do estudo e na possibilidade de comparação dos resultados com outros trabalhos que utilizarem essa metodologia (Marais et al., 2010b).

Observou-se que a categorização inicial proposta no estudo foi idêntica à categorização com os critérios padronizados internacionais (Marais et al., 2010 b) em $98 \%$ dos pacientes no estudo prospectivo e em $100 \%$ daqueles no estudo retrospectivo. Apenas dois pacientes da fase prospectiva, que foram classificados como "MTB Possível" segundo critérios adotados da literatura, foram classificados como "MTB Provável" pelos critérios de Marais et al. (2010b). Isso sugere que a metodologia de categorização diagnóstica do desenho inicial do estudo foi adequada na classificação dos casos suspeitos de MTB, podendo ser utilizada na prática clínica, uma vez que é mais simples. 
A sensibilidade da nRT-PCR na categoria "MTB Provável" de Marais et al. (2010b) foi 50\%, menor que aquela observada na categoria homônima definida inicialmente pelo presente estudo (67\%). Isso se justifica pelo fato de que oito pacientes foram classificados como "MTB Provável", segundo Marais et al. (2010b), e seis segundo a classificação do presente estudo. Esses dois pacientes adicionais na categoria "MTB Provável" de Marais, que foram classificados como "MTB Possível" segundo o presente estudo, tiveram resultado negativo da nRT-PCR. Eles foram classificados como "MTB Provável" pelos critérios de Marais, no entanto não tiveram BAAR isolado fora do SNC. A categoria "MTB Provável" proposta pelo presente estudo - na qual era imprescindível o isolamento do BAAR - foi mais exigente que a categoria homônima de Marais, que não apresentava esse critério.

O achado de BAAR fora do SNC constitui um importante elemento indicador da MTB (Thwaites et al., 2009). Já foi demonstrado por outros autores que a evidência de TB em outro sítio, num contexto clínico-laboratorial compatível com MTB, aumenta a possibilidade do diagnóstico através da PCR (Ahuja et al., 1994; Brienze et al., 2000; Principi; Esposito, 2012). Pode-se aventar a hipótese que, esses dois casos sem BAAR isolado fora do SNC e incluídos na categoria "MTB Provável" de Marais et al. (2010b) teriam outros diagnósticos não identificados na extensa investigação diagnóstica do presente estudo.

A menor sensibilidade (50\%) na categoria "MTB Provável" padronizada (Marais et al., 2010b), também poderia estar associada ao seguinte achado: os quatro pacientes desse grupo, que tiveram resultado negativo da nRT-PCR, não apresentavam estágio clínico avançado de MTB (BMRC, 1948) e dois deles não eram infectados por HIV. O estágio de gravidade de uma doença pode afetar a sensibilidade do teste (van Stralen et al., 2009), e no caso específico da MTB, esses estágios clínicos menos graves poderiam ser paucibacilares (Puccioni-Sohler; Brandão, 2007), prejudicando o desempenho da nRT-PCR. Além disso, alguns autores já observaram que a carga bacilar é maior em pacientes com HIV, sendo os resultados de baciloscopias e culturas melhores nesse contexto (Dube et al., 1992; Katrak et al., 2000; Thwaites et al., 
2005; Puccioni-Sohler; Brandão, 2007).

Quanto aos fatores clínicos eventualmente implicados na menor sensibilidade (25\%) da categoria "MTB Possível", destaca-se que os critérios utilizados nessa categoria são sugestivos de MTB, mas essa associação é mais frágil que para a categoria "MTB Provável". Observou-se que não houve diferença significativa entre o escore de Marais et al. (2010b) dos pacientes da categoria "MTB Possível" e aqueles classificados como "Não MTB", assim como não houve diferença entre os classificados como "MTB Provável" e "MTB Definitiva". No entanto, foi observada diferença significativa entre o escore da categoria "MTB Definitiva" e a "MTB Possível" (Gráfico 4). Isso poderia sugerir que os pacientes classificados como "MTB Possível" teriam maior semelhança com aqueles com outros diagnósticos estabelecidos (Não MTB). Não se pode afirmar categoricamente que todos os casos na categoria "MTB Possível" eram de MTB, apesar da extensa investigação. Doenças não infecciosas ou microorganismos não identificados poderiam ser os responsáveis pelo quadro clínico. Assim, os resultados negativos da nRT-PCR nessa categoria poderiam não ser falso-negativos, mas sim casos com outros diagnósticos não confirmados.

Além disso, observou-se que nenhum dos casos dessa categoria tinha doença em estágio clínico avançado (BMRC, 1948) quando comparado com aos quatro pacientes da categoria "MTB Definitiva" (Tabela 7). Considerando que todos os pacientes com suspeita de MTB foram tratados, a única categoria em que não ocorreram óbitos foi a "MTB Possível”.

Outra limitação foi que uma das pacientes desse grupo já tinham 10 dias de tratamento com esquema anti-tuberculostático e outro paciente também foi tratado para meningite bacteriana com ceftriaxona, apesar de nenhum agente ter sido isolado. Alguns trabalhos mostraram que a PCR pode ser útil no diagnóstico de pacientes já em tratamento de MTB (Scarpelini et al., 1995; Brienze et al., 2000; Takahashi et al., 2007), mas é difícil especificar até quantos dias ainda mantém essa propriedade (Takahashi et al., 2007; Huang et al., 2009). 
Um trabalho recente com bons resultados optaram por não incluir a categoria "MTB Possível" (Patel et al., 2013), eventualmente, pelas dúvidas que ela pode gerar na interpretação do valor diagnóstico da PCR. Optou-se por não excluir essa categoria do presente estudo porque é exatamente nesses pacientes que um resultado positivo da nRT-PCR auxilia muito no diagnóstico. $\mathrm{Na}$ prática clínica, esse paciente é aquele em que o médico pode encontrar algumas características clínico-laboratoriais sugestivas de MTB, mas não consegue identificar $M$. tuberculosis dentro ou fora do SNC e também não é capaz de excluir outros diagnósticos diferenciais. Nesses casos, um resultado negativo não permitiria excluir a possibilidade da infecção, mas devido à alta especificidade da nRT-PCR, um resultado positivo confirmaria o diagnóstico de MTB.

Alguns trabalhos na literatura já utilizaram as categorias descritas por Marais et al. (2010b) na classificação de seus pacientes com suspeita de MTB (Haldar et al., 2012; Hristea et. al., 2012; Ho et. al, 2012, Pehlivanoglu et al., 2012). Entre esses estudos, Haldar et al. (2012) utilizaram as categorias padronizadas para a avaliação de técnicas da PCR. Uma das técnicas da PCR avaliadas foi uma PCR em tempo real, cujo alvo era uma região com 144 pares de base do gene devR. Essa técnica avaliada mostrou ótimos resultados (sensibilidade e especificidade de $100 \%$ e $96 \%$, respectivamente), quando comparados com os dados da categoria "MTB Definitiva". Nas categorias "MTB Provável" e "MTB Possível", a sensibilidade e a especificidade foram muito elevadas: 98\% (IC95\%: 94 - 99\%). No entanto, esses resultados ainda não foram reproduzidos em outros estudos.

Fatores técnicos que poderiam explicar os resultados negativos da nRT-PCR nas categorias "MTB Provável" e "MTB Possível" no estudo prospectivo incluem: i. o pequeno volume de líquor utilizado; ii. a baixa carga bacilar nas amostras; iii. a dificuldade na lise da parede celular da micobactéria; iii. a presença de inibidores da PCR no LCR dos pacientes; iv. a perda de DNA durante o processo de purificação; $v$. a distribuição desigual das micobactérias nas amostras clínicas (Bhigjee et al., 2007; Gascoyne-Binzi; Hawkey, 1999; Deshpande et al., 2007; Haldar et al., 2009; Heringer et al., 2005; Huang et al., 
2009; Melzer et al., 1999). Procurou-se minimizar esses fatores: $i$. utilizando um maior volume de LCR (no mínimo $1 \mathrm{~mL}$ ) que em outros estudos (Bonington et al, 1998; Brienze et al, 2000; Kusum et al, 2011); ii. centrifugando as amostras (Patel et al., 2013); iii. adicionando lisozima e mutanolisina; iv. usando controles internos de amplificação. No entanto, é difícil garantir que todos os fatores técnicos implicados na baixa sensibilidade da PCR (Pai et al., 2003; Thwaites et al., 2013) puderam ser resolvidos. Estudos posteriores poderiam avaliar melhoras em cada um desses fatores como uma maneira de garantir uma maior sensibilidade em pacientes sem diagnóstico definitivo de MTB, mas com alta suspeição clínica.

Sabe-se que, para o melhor rendimento da cultura e baciloscopia, quantidades maiores de LCR devem ser utilizados, assim como punções repetidas em dias seriados (Thwaites et al., 2009). O volume do líquor padronizado no presente estudo foi de $1-2 \mathrm{~mL}$. Apesar de não haver um estudo específico avaliando o rendimento de diferentes quantidades de líquor nas diversas técnicas da PCR, pode-se supor que maiores volumes estariam associados à maior possibilidade de encontrar DNA do M. tuberculosis nas amostras (Kox et al., 2005; Kulkarni et. al, 2005), aumentando a sensibilidade da nRT-PCR.

Outro fator que poderia explicar a menor sensibilidade da nRT-PCR nas categorias "MTB Provável" e "MTB Possível" é o alvo genético escolhido: apesar da alta especificidade (Lee et al., 1994), o gene mpt64 possui apenas uma cópia no DNA do M. tuberculosis (Cole et al., 1998). Outros alvos como a sequência de inserção 6110 (IS6110), possuem diversas cópias no genoma, facilitando a amplificação e detecção (Sankar et al., 2011). No entanto, há relatos de cepas de M. tuberculosis que não possuem o IS6110, o que poderia gerar resultados falso-negativos em até $40 \%$ dos casos (Das et al., 1995; Dar et al., 1998; Agasino et al., 1998; Melzer et al., 1999; Chauhan et al., 2007; Chadir et al., 2012). Um trabalho realizado com cerca de 1000 cepas de $M$. tuberculosis isoladas do escarro de pacientes do estado de São Paulo mostrou a presença de mpt64 em 100\% delas (Gonçalves, 2011), o que corrobora a escolha por esse alvo em nosso estudo. Kusum et al. (2011) realizou um 
trabalho com uma PCR com múltiplos alvos e mostrou que o gene mpt64 permitiu a identificação de casos que não seriam detectados apenas pela IS6110. Esses alvos adicionais, que tornam o exame mais dispendioso, trouxeram um benefício pequeno quando comparados à PCR com apenas o mpt64 como alvo, como a utilizada no presente estudo.

Outro problema com a IS6110 são os resultados falso-positivos, decorrentes da homologia entre seus fragmentos e partes do genoma de outras micobactérias (Lee et al., 1994; Kent et al., 1995; Sankar et al., 2011). Os resultados falso-positivos por homologia com outros micro-organismos também foram descritos com uma sequência de cópia única no DNA do M. tuberculosis, denominada 65 kDA heat shock protein (Lee et al., 1994; Rafi et al., 2007), dificultando seu uso e tornando o gene mpt64 o alvo aparentemente mais adequado para o diagnóstico da MTB.

O gene rpoB também tem sido utilizado no diagnóstico de casos suspeitos de MTB (Huang et al., 2009; Patel et al., 2013), com a vantagem de estar em uma região relacionada com a maioria das mutações que conferem resistência à rifampicina (Telenti et al., 1993; Laurenzo; Mousa, 2011). Huang et al. (2009) demonstraram $86 \%$ de sensibilidade com esse método, mas apenas dois casos de sua série tinham confirmação microbiológica (padrãoouro). É interessante notar que, caso essa metodologia fosse aplicada à casuística do presente estudo, ela poderia identificar resistência em dois pacientes que tiveram MTB por cepa resistente à rifampicina, no entanto, ela não seria capaz de identificar a resistência à isoniazida em três pacientes. $O$ padrão de resistência à isoniazida é mais complexo que o da rifampicina, por frequentemente envolver mutações em diversos genes. Por isso, é mais difícil de ser identificado nas PCR realizadas diretamente em amostras clínicas (Laurenzo; Mousa, 2011).

Patel et al. (2013) desenvolveram o primeiro estudo com grande número de pacientes ( $n=204)$ com suspeita de MTB, em um centro de pesquisa na África do Sul, para avaliar a plataforma GeneXpert MTB/RIF®. Essa metodologia também utiliza o gene rpoB como alvo, com uma técnica 
heminested de PCR em tempo Real semelhante à utilizada no presente estudo. Considerando os casos definitivos de MTB, a sensibilidade e especificidade do teste foram de 67\% (IC95\%: 53 - 79) e 94\% (IC95\%: 85 - 98). Após avaliação por estudos mais abrangentes e com a redução dos custos, poderá ser uma ferramenta promissora no diagnóstico da MTB. Destaca-se a facilidade da sua instalação e operação por pessoal pouco experiente em laboratórios locais, o que permite a maior facilidade no acesso ao diagnóstico em locais distantes dos centros de referência. Quando comparada ao GeneXpert MTB/RIF®, a nRT-PCR avaliada no presente estudo apresentou melhor desempenho nos casos definitivos de MTB (sensibilidade 100\%, IC95\%: 70 - 100). No entanto, conta com procedimentos um pouco mais complexos de preparação da amostra e etapas não automatizadas, o que poderia limitar sua descentralização para laboratórios de menor complexidade.

Com os resultados do estudo prospectivo, a nRT-PCR foi aprovada para a investigação de casos suspeitos de MTB na rede pública do Estado de São Paulo no segundo semestre de 2010. Entre 2010 e o primeiro semestre de 2013, cerca de 1.200 amostras de LCR foram encaminhadas de diversos hospitais para realização da nRT-PCR no Laboratório de Meningites Bacterianas do Instituto Adolfo Lutz.

\section{Casuística do estudo prospectivo}

Observou-se uma frequência de TB prévia de 34\% entre os pacientes avaliados. Entre os pacientes com diagnóstico confirmado de MTB essa proporção foi maior (56\%) que aqueles da categoria "Não MTB" (31\%), conforme já observado em outros estudos (Marais et al., 2010a), especialmente entre os infectados pelo HIV (Berenguer et al., 1992; Croda et al., 2010).

A MTB é reconhecida como uma das três principais infecções oportunistas do SNC de pacientes com HIV (Lanjewar et al., 1998; Tan et al., 2012), também no contexto brasileiro (Vidal et al., 2005; Oliveira et al., 2006). No Instituto de Infectologia Emílio Ribas a MTB também representa uma 
importante complicação neurológica em pacientes com HIV (Croda et al., 2010), ocupando o terceiro lugar entre as doenças do SNC, depois da toxoplamose do SNC e a meningoencefalite criptocóccica (Vidal et al., 2005; Oliveira et al., 2006)). A amostragem incluída no presente estudo refletiu bem essa distribuição de doenças neurológicas relacionadas ao HIV, sendo bem representativa dessa população (Schunemann et al., 2009). Nos casos com diagnóstico definido, a MTB foi a quarta causa mais freqüente (8 pacientes), precedida pela toxoplasmose $(n=16)$, criptococose $(n=15)$ e meningoencefalite por CMV $(n=9)$.

Devido ao amplo espectro de complicações neurológicas que podem acometer os pacientes com HIV (Lucas et al., 1993; Lantejewar et al., 1998; Kibayashi et al., 1999; Rana et al., 2000; Tan et al., 2012), o diagnóstico oportuno da MTB mostra-se ainda mais importante nesses indivíduos. A nRTPCR avaliada no presente estudo teve um papel importante na identificação da MTB nesses pacientes. As tentativas de estabelecer um diagnóstico rápido e definitivo contribuem para minimizar as falhas, decorrentes do atraso no início do tratamento de MTB ou dos efeitos tóxicos de terapias empíricas de amplo espectro (Thwaites et al., 2013).

Entre algumas variáveis laboratoriais comparadas entre os pacientes da categoria "MTB Definitiva" e "Não MTB", observou-se algumas diferenças significativas. A quantidade de leucócitos, a proporção de neutrófilos e a dosagem de proteína no LCR foram significativamente maiores na categoria "MTB Definitiva" $(p<0,01)$, enquanto glicose no líquor e razão "Glicose LCR/Glicose soro" foram menores nos pacientes dessa categoria $(p<0,01)$. Esses achados são classicamente associados com a MTB (Thwaites et al., 2002; Marais et al., 2010b, Ho et al., 2013), mas isoladamente não permitem confirmar ou descartar o diagnóstico. Há diversos trabalhos ilustrando casos atípicos de MTB (Laguna et al., 1992; Katrak et al., 2000; Heringer et al., 2005; Marais et al. 2010a), incluindo pacientes sem qualquer alteração quimiocitológica no LCR (Croda et al., 2010).

Observou-se que o BAAR foi identificado na baciloscopia do LCR de 
apenas um paciente, que também teve a cultura positiva para M. tuberculosis. Apesar de sua baixa positividade, é um exame rápido, barato e de fácil execução, permitindo o diagnóstico imediato de MTB (Thwaites et al., 2002; Puccioni-Sohler; Brandão, 2007). A baciloscopia direta através da coloração de Ziehl-Neelsen deve ser sempre realizada, analisando-se grande número de campos, com maiores volumes de LCR e após centrifugação adequada (Thwaites et al., 2013). Chen et al. (2012) mostraram que modificações simples na coloração Ziehl-Neelsen, possibilitaram a melhor identificação de BAAR intracelular no LCR de todos os 29 pacientes com MTB. Embora sejam resultados de um único estudo, esses dados oferecem uma boa perspectiva de readequação e melhora de um método simples e barato na investigação diagnóstica de MTB.

Oito pacientes do estudo tiveram a cultura positiva, dentre eles dois pacientes com $M$. tuberculosis resistente à Rifampicina e Isoniazida e um apenas à Isoniazida. A cultura fornece sensibilidade maior que a baciloscopia: é importantíssima não apenas para diagnóstico, mas também para estudos epidemiológicos e na determinação da sensibilidade (Hermans et al. 1990; Twhaites et al., 2013). Com o aumento global de prevalência de cepas resistentes (WHO, 2013), o tratamento inadequado de MTB em pacientes infectados com cepas MDR está associado à maior morbimortalidade (Thwaites et al., 2013). Nos três pacientes que tiveram cepas resistentes isoladas no LCR, ocorreu readequação do esquema terapêutico. Não houve óbitos entre eles durante a internação.

A TC de crânio não foi útil para discriminar os pacientes com MTB. Onze pacientes com suspeita de MTB tiveram achados típicos (hidrocefalia em sete e três com hiperdensidade meníngea basal). No entanto, esses achados também foram observados em 10 doentes com outros diagnósticos confirmados. Apesar de infrequente na meningite criptocóccica, 2 pacientes com esse diagnóstico tiveram hidrocefalia. $\mathrm{O}$ achado mais frequente em todas as categorias clínicas foi a atrofia cortical (40,2\%) provavelmente devido à alta prevalência de pacientes infectados por HIV entre os sujeitos estudados (McMurtray et al., 2008, Tan et al., 2012). 
Revisões recentes (Marais et al., 2010a; Marx et al., 2011) apontam que as taxas de mortalidade por MTB são variáveis (13 - 72\%) conforme o perfil dos pacientes estudados. No entanto, em países em desenvolvimento e entre pacientes com HIV, essa taxa é habitualmente maior (Karstaedt et al., 1998; Katrak et al., 2000; Marais et al., 2010a), chegando a 80\% em estudos recentes (Luma et al., 2012). Foram observados 23 óbitos entre os pacientes incluídos no presente estudo, ocorrendo uma maior proporção de mortes entre aqueles com diagnóstico definitivo de MTB (44\%). Croda et al. (2010) também encontraram uma mortalidade semelhante $(41 \%)$ entre pacientes com MTB no IIER. Observou-se que uma maior proporção de pacientes da categoria "MTB Definitiva" (44\%) foi classificada no estágio III (BMRC, 1948), com relação aos classificados com "Não MTB" (4\%), refletindo uma maior gravidade dos casos de MTB quando comparados aos outros diagnósticos. Conforme outros trabalhos (Kent et al., 1993; Katrak et al. 2000; Cecchini et al., 2007; Torok et al., 2008, Luma et al., 2012), também observou-se que o estágio clínico avançado esteve relacionado à maior mortalidade: ocorreu óbito em três dos quatro pacientes com diagnóstico confirmado de MTB e estágio clínico III.

As estratégias de diminuição da letalidade estão baseadas exatamente na capacidade de diagnosticar precocemente a MTB, para que o tratamento específico seja instituído antes que os pacientes atinjam estágios clínicos mais avançados (Marx et al., 2011; Twhaites et al., 2013). Nesse contexto, a nRTPCR é uma ferramenta muito útil. O tempo para realização da nRT-PCR avaliada foi de 24 horas, quando comparada aos 14 dias necessários para a positividade nos melhores meios de cultura (Leitritz et al., 2001; Venkataswamy et al., 2007). Além disso, por ser uma técnica in house, no contexto do serviço público (Dora et al., 2008), seu custo-benefício é maior que as técnicas comerciais como a TB AMPLICOR (Roche $\AA$ ), que além de ser mais cara, apresenta resultados de sensibilidade mais baixos (Bonington et al., 1998, 2000; Pai et al., 2003; Dinnes et al., 2007; Tortoli et al., 2012). 


\subsection{Estudo retrospectivo}

O estudo retrospectivo incluiu um número menor de pacientes que 0 estudo prospectivo e apresentou a mesma especificidade, com uma sensibilidade menor (83\%) entre os casos com padrão-ouro positivo. Apesar da qualidade dos dados incluídos na análise retrospectiva não ser semelhante aos da análise prospectiva, essa fase permitiu o desempenho do teste em condições de rotina clínica.

Alguns pacientes foram excluídos por não preencherem os critérios de inclusão ou por não apresentarem dados clínicos suficientes para categorização diagnóstica. Isso poderia sugerir que exames foram solicitados com uma baixa probabilidade pré-teste, o que reduz a chance de encontrar pacientes verdadeiramente com MTB (van Stralen et al., 2009) e aumentam o custo da investigação diagnóstica (Chedore et al., 2002). Segundo a OMS (WHO, 2013), algoritmos diagnósticos devem começar com a escolha apropriada das ferramentas de rastreamento para identificar pessoas em situação de risco. Rastreamentos pouco adequados poderiam influenciar negativamente o desempenho dos testes diagnósticos (van Stralen et al., 2009).

Hristea et al. (2012) descreveram a aplicação dos critérios padronizados por Marais et al. (2010b) em um estudo retrospectivo nos quais os pacientes já tinham o diagnóstico definitivo de MTB. Nesse estudo, 93\% dos doentes seriam classificados nas "MTB Provável" ou "MTB Possível". Os autores descreveram que uma das limitações do estudo foi a falta de dados necessários para preencher todos os critérios diagnósticos de Marais et al. (2010b), o que poderia explicar o fato de 7\% dos pacientes não terem sido classificados em alguma das categorias suspeitas de MTB. No presente estudo, também se observou que parte dos pacientes que poderiam ser incluídos na fase retrospectiva foram excluídos porque não apresentavam registro no prontuário dos dados clínicos mínimos necessários para preenchimento do escore de Marais et al. (2010b) 
Uma hipótese para justificar a menor sensibilidade no estudo retrospectivo seria o menor cuidado na coleta, conservação e processamento das amostras nos laboratórios locais, assim como o transporte para 0 laboratório de referência. Durante o estudo prospectivo, o pesquisador era responsável por todas essas etapas. Existia uma maior garantia de coleta de volumes adequados $(1-2 \mathrm{~mL})$ de $\mathrm{LCR}$, maior qualidade de conservação das amostras estocadas e envio rápido do material para o Laboratório de Meningites Bacterianas no IAL.

Apesar das orientações dadas aos médicos e técnicos de laboratório dos hospitais envolvidos nessa fase retrospectiva, incluindo instruções escritas (Anexo D), observou-se que a qualidade das amostras de LCR era inferior. A maioria tinha volume pequeno $(<2 \mathrm{~mL})$, algumas delas menor que $1 \mathrm{~mL}$, impedindo a realização da técnica e sendo excluídas do estudo. Como mencionado, volumes menores de LCR estão associados ao menor desempenho da cultura e das técnicas da PCR (Chedore et al., 2002).

Outra hipótese para justificar o menor rendimento da nRT-PCR nessa fase do estudo seria a falta de coleta em tubo separado. Caso a amostra de LCR a ser enviada para a nRT-PCR fosse coletada junto com as amostras para culturas e estudo quimiocitológico, a amostra a ser enviada para o IAL deveria ser manipulada e colocada em outro frasco. Isso aumenta o risco de contaminação e o risco do envio apenas do sobrenadante após centrifugação preliminar nos laboratórios locais. De fato, observou-se que entre as amostras enviadas para o IAL, algumas não apresentavam amplificação de DNA humano (um dos controles internos do método), sugerindo que a amostra era apenas o sobrenadante de centrifugação prévia e não o LCR total.

Com relação à casuística do estudo retrospectivo, observou-se que a prevalência de TB prévia (32\%) e HIV (86\%) foi semelhante a do estudo prospectivo (34 e 90\%, respectivamente). Também se observou uma homogeneidade entre os estudos no que diz respeito à distribuição dos pacientes nas categorias diagnósticas de MTB, assim como nas doenças encontradas na categoria "Não MTB". Entre as diferenças entre os estudos, 
destaca-se a ausência de pacientes na categoria "MTB Possível" no estudo retrospectivo. Como diversos indivíduos foram excluídos por ausência de registros suficientes no prontuário, pode-se aventar a hipótese de que alguns desses pacientes excluídos poderiam compor essa categoria caso se dispusesse dos seus dados completos (Hristea et al., 2012).

\subsection{Considerações finais}

Optou-se por não incluir a resposta à terapêutica empírica para MTB como critério de confirmação diagnóstico de casos suspeitos. Esse critério também não foi utilizado nas definições internacionais de MTB padronizadas por Marais et al. (2010b). Quadro clínico e parâmetros liquóricos não são suficientes para discriminar MTB de outras doenças neurológicas (Garg et al., 1999; Katti et al., 2004; Puccioni-Sohler; Brandão, 2007) e a terapêutica empírica é um importante critério na prática clínica. No entanto, seu uso na avaliação de novas ferramentas diagnósticas poderia diminuir erroneamente a sensibilidade do método (van Stralen et al., 2009). Quando a terapêutica empírica instituída é exclusiva para MTB, há o risco atrasar o diagnóstico correto no caso de outra afecção ser a responsável pelo quadro clínico. Se a terapia empírica é de amplo espectro, além da maior chance de toxicidade medicamentosa, torna-se difícil avaliar o agente responsável pela melhora do paciente e para definir o diagnóstico.

Entre HIV positivos, nos quais a gama de infecções oportunistas do SNC é maior, a avaliação da resposta terapêutica se torna ainda mais complicada. Alguns pacientes, sem confirmação microbiológica e sem resposta à terapia inicial, podem ser tratados empiricamente para dois ou mais agentes (p.ex.: encefalite por CMV, toxoplasmose do SNC e MTB). A presença de corticoide no esquema terapêutico, essencial para a terapia de MTB (Thwaites et al., 2013), pode confundir a tentativa de confirmação diagnóstica no contexto da pesquisa de ferramentas diagnósticas. Micro-organismos testados com menor frequência (p.ex.: Brucella spp., Listeria spp. e micobactérias não 
tuberculosas) poderiam ser os responsáveis por manifestações clínicas e liquóricas semelhantes à MTB em seus estágios iniciais. Quadros clínicos leves poderiam ser causados por agentes virais como os enterovírus, prevalentes em nosso meio (Dos Santos et al. 2006), vírus Herpes tipo 6 (HHV-6) e próprio HIV (Hollander, 1987, 1994). Quando esses quadros clínicos - habitualmente autolimitados - são abordados com a corticoterapia presente no esquema de tratamento de MTB, poderia ser observada uma melhora dos sintomas. Se não ocorrer isolamento do agente, dificilmente seria possível atribuir um diagnóstico específico após o início da terapia.

No entanto, na prática clínica, pacientes sem diagnóstico específico de seus quadros neurológicos, mas com manifestações clínicas graves, requerem tratamento empírico abrangendo diversas etiologias, inclusive a MTB. Quando ocorre melhora clínica, é difícil realizar o descalonamento terapêutico. Nesse contexto, associada a outras provas diagnósticas e ao correto julgamento clínico, a nRT-PCR para M. tuberculosis poderia ser de grande valia (Caws et al., 2000). Ela poderia evitar a manutenção de tuberculostáticos em pacientes com pouca probabilidade de MTB e um resultado negativo. $O$ doente poderia ser poupado dos efeitos tóxicos das medicações e do incômodo desnecessário de uma terapia de pelo menos nove meses. Ocorreria ainda diminuição da interação com outros medicamentos, especialmente entre pacientes HIV positivos.

Uma das limitações do presente estudo foi o baixo número de pacientes com MTB confirmada por diagnóstico microbiológico. A natureza paucibacilar do LCR e a baixa sensibilidade dos métodos microbiológicos tradicionais dificulta a identificação desses casos. Adicionalmente, apesar da alta prevalência da TB (WHO, 2013), a MTB é uma doença relativamente infrequente (Phypers et al., 2006; Ducomble el al., 2013). É difícil identificar doenças infrequentes em estudos prospectivos. Azevedo et al. (2013) realizaram um levantamento epidemiológico que identificou 251.853 casos de meningite com etiologia definida notificados ao Sistema Nacional de Agravos Notificação (SINAN) entre 2001 e 2012 no Brasil. A MTB correspondia a apenas $1,7 \%$ dos casos. No entanto, quando comparado a estudos 
prospectivos com pacientes com confirmação microbiológica, o número de casos do presente estudo supera diversos estudos (Liu et al., 1994; Lee et al., 1994), incluindo estudos de PCR comerciais (Bonington et al., 1998, 2000) e outros trabalhos no cenário nacional (Brienze et al., 2000; Dora et al., 2008).

Outra limitação do estudo é a aplicação dos resultados em unidades de saúde de menor porte. Apesar da maior simplicidade da reação da nRT-PCR, ela requer um bom treinamento da equipe do laboratório e equipamentos específicos. Assim como observado por outros autores (Pai et al., 2003; Dinnes et al., 2007; Dora et al., 2008; Thwaites et al., 2009; 2013), existe uma dificuldade de reprodutibilidade dos resultados da PCR in house em contextos diferentes daqueles em que foram criadas. No entanto, a busca por um diagnóstico mais preciso e rápido condicionou uma rápida expansão das pesquisas estudando diversas técnicas para o diagnóstico da MTB nos últimos quatro anos (Thwaites et al., 2013), sendo a maioria delas metodologias in house. As metodologias rapidamente se tornam "obsoletas" num contexto em que as técnicas da PCR apresentam melhorias operacionais que vão sendo incorporadas nos testes mais recentes. Isso ocorreu no caso plataforma comercial GeneXpert MTB/RIF $\AA$, que incorporou melhorias de processamento de amostras e exatamente a técnica nested com o tempo real para o diagnóstico de MTB (Patel et al., 2013). Ainda que onerosa e testada apenas em um centro, essa técnica é, sem dúvida, muito interessante por sua praticidade. Julga-se que a nRT-PCR avaliada no presente estudo continua sendo uma ótima opção para o diagnóstico da MTB na rede pública do Estado de São Paulo, até que esses métodos mais recentes estejam aprovados para diagnóstico da MTB e amplamente disponíveis no Brasil.

Os pontos fortes do presente estudo incluem: (I) a casuística é bem representativa (Schunemann et al., 2009) de pacientes com doenças neurológicas relacionadas ao HIV, contexto no qual o diagnóstico de MTB é frequentemente investigado. A incerteza diagnóstica nesses casos é legítima e o presente estudo reflete bem esse aspecto da prática clínica; (ii) estudos prospectivo e retrospectivo de uma mesma técnica, permitindo avaliar as qualidades do rigor metodológico do estudo prospectivo e as limitações 
associadas ao baixo limiar para a solicitação do exame e ao processamento das amostras durante a rotina. A semelhança entre os resultados encontrados em ambos os estudos confirmam a qualidade e a reprodutibilidade da metodologia da nRT-PCR; (iii) a nRT-PCR foi realizada em um laboratório distinto daquele em que os demais exames eram realizados (mascaramento), prevenindo interferências e vieses nos resultados; (iv) a rapidez do ensaio da nRT-PCR quando comparada à cultura na confirmação diagnóstica da MTB (iii) a adoção das categorias padronizadas de Marais et al. (2010b), que permite a comparação e reprodução do presente estudo em outros contextos. O uso das categorias diagnósticas possibilitou a avaliação da nRT-PCR em pacientes com suspeita de MTB e padrão-ouro negativo, situação comum na prática clínica. Conforme os resultados da nRT-PCR em pacientes das categorias "MTB Definitiva" e "Não MTB", um resultado positivo da nRT-PCR em pacientes com suspeita de MTB constitui um forte indício do diagnóstico. De modo adicional, não há estudos prévios que avaliaram todas as categorias diagnósticas de Marais et al. (2010b) em um número semelhante de pacientes com infecção por HIV.

Estratégias que poderiam ser avaliadas em estudos posteriores para aumentar a sensibilidade do método utilizado neste estudo incluem: (I) coleta padronizada de maior volume de LCR para realização da nRT-PCR (Chedore et al., 2002); (ii) centrifugação de um maior volume de LCR (Patel et al., 2013); (iii) maior número de amostras de um mesmo paciente (Chedore et al., 2002); ( $v i)$ avaliação do custo-benefício do uso de múltiplos alvos genéticos do $M$. tuberculosis na reação nRT-PCR (Kusum et al., 2011); (iv) utilização de técnicas para concentrar o DNA micobacteriano, como os "filtrados" de líquor descritos por Haldar et al. (2009).

A partir do presente estudo, que incluiu um grande número de indivíduos com suspeita de MTB, poder-se-ia sugerir algumas estratégicas na investigação desses pacientes na prática clínica: ( $I$ coletar exames para cultura, análise quimiocitológica e PCR em tubos separados e devidamente identificados; (ii) coletar maior volume de LCR em casos suspeitos, pois todos os exames específicos (baciloscopia, cultura e PCR) melhoram seu rendimento 
com maiores volumes; (iii) proximidade com equipe laboratorial para orientar procedimentos mais meticulosos nos casos em que a suspeita de MTB é maior (p. ex.: exame de maior número de campos na baciloscopia, maior tempo de observação das lâminas, centrifugação de maior volume de LCR antes da inoculação nos meios de cultura); (iv) realizar extensa investigação de TB em outros sítios, mesmo na ausência de sintomas sugestivos (amostras de escarro, lavado gástrico, raios x e TC de tórax, pesquisa de linfadenopatia, etc.); ( $v$ ) ampliar a investigação de diagnósticos diferenciais, mesmo que o paciente esteja recebendo terapia empírica de MTB.

A nRT-PCR complementa, mas não substitui o julgamento clínico no diagnóstico da MTB. As medidas do desempenho de um teste não são instâncias isoladas. Estão inseridas em um contexto de avaliação clínica prévia das chances de um paciente ter MTB, conforme suas características, sintomas e prevalência da doença. Isto influenciará a chance posterior de doença diante do resultado de um teste laboratorial (van Stralen et al., 1999). É importante destacar que a nRT-PCR é um método rápido, sensível e específico, no entanto não é isento de custos e de um diligente trabalho por parte de uma equipe laboratorial bem treinada. Não é adequado para a triagem massificada de MTB, mas sim um como exame confirmatório. É essencial utilizar uma criteriosa avaliação clínica para identificar os pacientes com maior probabilidade de ter MTB antes de solicitar o teste (Chedore et al., 2002).

A potencial gravidade da MTB requer o tratamento de todos os casos em que a dúvida diagnóstica não pode ser adequadamente resolvida (Thwaites et al., 2013). Exames negativos de baciloscopia, cultura e biologia molecular não são suficientes para descartar a infecção em um paciente com alta probabilidade de ter MTB (Melzer et al., 1999; Thwaites et al, 2013). A MTB não é um diagnóstico de exclusão (Jongeling; Pisapia, 2013), devendo ser considerada mesmo diante de parâmetros liquóricos e apresentações clínicas pouco usuais em pacientes de áreas de alta prevalência (Laguna et al., 1992; Heringer et al., 2005; Croda et al., 2010).

A análise médica judiciosa baseada em dados clínico-laboratoriais e 
nos exames de imagem deve guiar a decisão diagnóstica e terapêutica (Thakur et al., 2010; WHO, 2013). Quanto mais discriminativas forem as variáveis nos quais o médico pode se basear (p. ex.: achado do BAAR fora do SNC), mais acertado será seu diagnóstico (Patel et al., 2010).

A nRT-PCR avaliada no presente estudo mostrou ser ferramenta rápida e efetiva, tornando-se um importante elemento na avaliação diagnóstica de pacientes com suspeita de MTB em hospitais públicos do Estado de São Paulo. A rapidez na confirmação diagnóstica da MTB melhora a abordagem do paciente (Thwaites et al., 2013), tanto por auxiliar na introdução precoce do tratamento, quanto por permitir o descalonamento de outras terapias quando uma abordagem empírica ampla é inicialmente adotada. Apesar da redução da sensibilidade observada na fase retrospectiva, a especificidade do teste manteve-se elevada. Os resultados desse trabalho permitem afirmar que, na prática assistencial, um resultado positivo da nRT-PCR confirma o diagnóstico de MTB, justificando sua adoção como ferramenta auxiliar na investigação dessa grave doença.

Quando utilizada para diagnóstico de MTB, a nRT-PCR deve ser analisada juntamente com o contexto epidemiológico, clínico e laboratorial, principalmente diante de um resultado negativo. Não é um exame que permite descartar a MTB em um contexto clínico sugestivo ("rule out test"). De acordo com os resultados de desempenho da nRT-PCR, seu principal valor na estratégia de investigação dessa doença consiste na confirmação oportuna do diagnóstico de MTB diante de um teste positivo ("rule in test"). 
6. ConCLUSÕES 


\subsection{Geral}

A nRT-PCR apresentou boa sensibilidade e excelente especificidade, demonstrando seu valor diagnóstico na identificação oportuna de casos de MTB.

\subsection{Específicas}

a) No estudo prospectivo, a nRT-PCR foi positiva no LCR de todos os pacientes com confirmação microbiológica de MTB e negativa em todos os pacientes com outros diagnósticos confirmados, apresentando sensibilidade e especificidade de $100 \%$.

b) No estudo retrospectivo, a sensibilidade foi de $83 \%$. Entre as amostras de pacientes com outros diagnósticos estabelecidos, a nRT-PCR foi negativa em todos os casos, com especificidade de $100 \%$.

c) A proporção de pacientes com a nRT-PCR positiva nas categorias clínicas foi de:

- Estudo prospectivo: 100\% para a categoria "MTB Definitiva", 66,7\% na "MTB Provável" e 16,8\% na "MTB Possível" (categorias definidas pelo presente estudo). Conforme as categorias internacionais padronizadas, a proporção foi de 100\%, 50\% e $25 \%$, respectivamente. Na categoria "Não MTB" de ambas as classificações, a nRT-PCR foi negativa em $100 \%$ dos casos.

- Estudo retrospectivo: 83\% para a categoria "MTB Definitiva" e 60\% na "MTB Provável". A especificidade nessa fase do estudo também foi de $100 \%$. Na categoria "Não MTB", a nRT-PCR foi negativa em $100 \%$ dos casos. 
7. ANEXos 
Anexo A

Ficha para a coleta de dados

(estudo prospectivo e retrospectivo) 
FICHA DE COLETA DE DADOS

\section{PROTOCOLO DE PESQUISA}

Ficha no:

ETIQUETA

Identificação: $\quad$ Data da admissão (PS): Unidade Internação:

Nome: $R G$ :

Sexo: (F) (M)

Idade:

Raça : (branca) (negra) (parda) (amarela)

Natural (cidade/estado)

Procedência Caso de HIV (S) (N) -

\section{Internacão Atual:}

Sintoma(s) principal(is): motivo(s) da internação):

Sintomas neurológicos: (cefaleia) (convulsões) (sonolência) (febre) (hemiparesia) (paraparesia) (alteração esfincteriana) (disfunção erétil) (parestesias) (disestesias) (alteração visual) (alteração de memória) (disartria). Outros:

Data do início sintomas neurológicos: 1

Antecedentes: (se souber apenas ano colocar 15/07/_ano)

Diagnóstico prévio de infecção pelo HIV: (Sim) (Não). Se sim, data:

Doença definidora de AIDS: (Sim) (Não). Qual?: Data?:

Doenças oportunistas prévias (Sim) (Não) Se sim quais? : : Data:

TB prévia: (Sim) (Não). Topografia(s) Diag.: (BAAR) (Cultura) (Presuntivo).

Data:

Tratamento completo da TB: (Sim) (Não). Esquema:

Usava ARV na admissão? (Sim) (Não). Esquema:

Nadir do CD4+: Data:

Último CD4+: Data: Última CV: $\log$ Data: 


\section{Exame físico:}

Estado Geral: (BEG) (REG) (MEG). PA: FR:

FC: $\mathrm{T}^{\mathrm{O}}$

Karnofsky: . Glasgow:

Adenomegalias: (Sim) (Não). Ausculta pulmonar: (normal) (anormal):

Hepatomegalia: (Sim) (Não). Esplenomegalia (Sim) (Não)

Outros achados:

Neurológico: (anotar apenas achados patológicos)

Glasgow: (RM__ $\mathrm{RV}_{\text {_ }} ; \mathrm{RO} \_$_ Total:__. Conteúdo da consciência:

Pupilas: Musculatura ocular externa:

Fala / linguagem:

Força muscular:

Reflexos profundos:

Sensibilidade (tátil / térmica / dolorosa / vibratória):

Rigidez de nuca: Sinais de Kernig / Brudzinsky:

Pares cranianos:

Coordenação / equilíbrio:

Marcha:

Movimentos involuntários:

Outros:

Imagem

CT / RM de crânio 1 (admissão) - Data:(

CT / RM de crânio 2 (controle) - Data:(

\section{Exames laboratoriais:}

$\mathrm{Hm} / \mathrm{Hb} / \mathrm{Hto}=$ Leuc

Glic: _ Cr/Ur: $\mathrm{Na}:$ K: ___ Alb:__ Outros (alterados): 
Líquor 1 (admissão): Data LCR: Cel $(\mathrm{N}$ $\mathrm{L}$ M E_ Outros PT Glic $\mathrm{Cl}$ Ex. direto TC LÁTEX

ADA: Culturas: Antibiograma:

PCR:

Líquor 2 - Data LCR: Cel $(\mathrm{N}$ L M E__ Outros

PT Glic Cl Ex. direto $\mathrm{TC}$ LÁTEX ADA: Culturas: Antibiograma:

PCR:

Outros exames

\section{Diagnóstico neurológico:}

Sindrômico: (meningite) (meningoencefalite) (encefalite focal c/ efeito expansivo) (encefalite focal sem efeito expansivo) (encefalite difusa) (demência) (alteração neuropsiquiátrica) (mielopatia) (poliradiculopatia) (neuropatia periférica).Outra:

Etiológico: (toxoplasmose cerebral) (neurocriptococose) (neurotuberculose) (neurosífilis) (meningite bacteriana) (LEMP) (leucoencefalopatia indeterminada) (linfoma primário do SNC) (encefalite herpética) (encefalite por varicella) (deficiência de vit. B12) (neuropatia periférica primária) (neuropatia tóxica) (alteração neuro-cognitiva associada ao HIV).

Outro:

Tratamento(s):

Evolucão clínica: (melhor) (igual) (pior) (seqüela). Explicar:

\section{Diagnósticos não neurológicos:}

Desfecho: (alta) (óbito). Causa direta do óbito:

Data:

\section{Observacões:}

\section{Médico responsável pelo preenchimento da ficha:}

Data: 
Anexo B

Termos de Consentimento Livre e Esclarecido 


\section{TERMO DE CONSENTIMENTO LIVRE E ESCLARECIDO (TCLE)}

PROTOCOLO DE PESQUISA

Instituto de Infectologia Emílio Ribas (IIER)

Centro de Referência e Treinamento em DST e Aids (CRT-DST/Aids)

\section{Nome do estudo: DETECÇÃO DE DNA DE MYCOBACTERIUM TUBERCULOSIS EM AMOSTRAS DE LIQUOR NO DIAGNÓSTICO E SEGUIMENTO DE PACIENTES COM MENINGITE TUBERCULOSA}

Você (ou seu familiar) foi admitido neste hospital devido à suspeita de uma doença que acomete o sistema nervoso, denominada de meningite tuberculosa. Essa doença manifesta-se principalmente com manifestações como dor de cabeça, febre, convulsões, sonolência, confusão, dentre outras.

A suspeita diagnóstica da meningite tuberculosa utiliza dados clínicos, estudos do líquido da espinha (líquor), e das imagens do cérebro (tomografia computadorizada ou ressonância magnética). A meningite tuberculosa requer de tratamento específico, motivo pelo qual o diagnóstico confirmatório é muito importante.

Estamos realizando uma pesquisa com o objetivo de conhecer melhor a meningite tuberculosa, uma das causas mais freqüentes de complicações neurológicas dos pacientes que são internados no Instituto de Infectologia Emílio Ribas. Também avaliaremos a utilidade de alguns exames que possam ajudar a diagnosticar essa doença de uma forma rápida e segura, visando evitar a o tratamento desnecessário e procedimentos mais invasivos. 
O objetivo deste termo é convidá-lo (você ou seu familiar) a participar da pesquisa. Caso você ou seu familiar aceitem será aplicada uma entrevista e exame físico. Esta pesquisa envolve a coleta inicial de $15 \mathrm{ml}$ líquor, $2 \mathrm{ml}$ a mais do que habitualmente é coletado. Punções adicionais são fundamentais para acompanhar a resposta ao tratamento. Rotineiramente, as punções de controle fazem parte do acompanhamento dos pacientes com meningite tuberculosa. Porém, para os objetivos deste estudo, essas coletas serão realizadas em momentos definidos após o início do tratamento. O volume de líquor será o mesmo da primeira punção $(15 \mathrm{~mL})$ e as punções serão realizadas duas semanas e um mês depois de iniciado o tratamento. Eventualmente serão necessárias outras punções, considerando sempre a evolução particular de cada caso e a discussão com a equipe médica de cada enfermaria.

As mostras coletadas servirão apenas e tão somente para o processamento dos exames que estamos estudando. Esses exames podem identificar no seu líquor a presença do micro-organismo que causa a meningite tuberculosa, uma bactéria denominada Mycobacterium tuberculosis. Esta identificação consiste na pesquisa do DNA dessa bactéria (exame chamado de "PCR").

Apesar de serem realizados por pessoas com experiência, existem alguns riscos que podem acontecer durante ou após a coleta do líquor, incluindo: dor no local da punção, sangramento, infecção e dor de cabeça.

Somente no final do estudo poderemos concluir a presença de algum benefício dos exames que estamos avaliando, não existindo benefício direto decorrente da participação no estudo. Todas as informações coletadas serão mantidas confidencialmente. Os dados serão armazenados em um computador 
e seu nome não aparecerá em nenhuma publicação, apresentação ou documento. Você poderá ter acesso aos resultados dos seus exames colhidos durante o estudo, bem como terá acesso, se assim desejar, às publicações pertinentes. Este estudo foi revisado a aprovado pelos Comitês de Ética em Pesquisa das Instituições participantes.

A sua participação neste estudo é voluntária. Este estudo não implica qualquer ônus para o paciente, assim como não trará nenhuma despesa financeira por sua participação. Caso você decida não participar, os cuidados médicos que você recebe não serão afetados de qualquer forma. Caso você aceite participar, você poderá retirar-se do estudo em qualquer momento, sem afetar os cuidados médicos. Por favor, sinta-se à vontade para discutir qualquer aspecto referente a este protocolo com os médicos pesquisadores responsáveis por este estudo Augusto César Penalva de Oliveira, telefone 9933-2917, e-mail: e Felipe Augusto Souza Gualberto, telefone 7653-0825 , email: felipe@emiloribas.sp.gov.br 


\section{FOLHA DE ASSINATURAS}

Eu, abaixo assinado, afirmo que li na íntegra e entendi completamente a Carta de Informações. Concordo que as informações a respeito de minha condição médica, que serão coletadas em meu prontuário, e os resultados obtidos através de meu líquor e sangue podem ser usados neste estudo. Entendo que mediante qualquer dúvida relacionada a este estudo poderei discutir com os Médicos Augusto César Penalva de Oliveira e Felipe Augusto Souza Gualberto. Minha participação é voluntária e livre de qualquer tipo de pressão ou coação. Da mesma maneira, poderei me desligar do estudo em qualquer fase de sua evolução, sem qualquer penalidade ou ônus ao meu atendimento pela Instituição.

Eu entendo que estas informações serão confidenciais e que meu nome não será mencionado em qualquer publicação deste estudo.

Nome:

Assinatura:

Data:

Nome do investigador:

Assinatura:

Data:

Caso o paciente não puder assinar:

Nome do familiar ou representante legal:

Grau de parentesco:

Assinatura:

Data: 
TERMO DE CONSENTIMENTO LIVRE E ESCLARECIDO

HOSPITAL DAS CLÍNICAS DA FACULDADE DE MEDICINA DA UNIVERSIDADE DE SÃO PAULO-HCFMUSP

\section{DADOS DE IDENTIFICAÇÃO DO SUJEITO DA PESQUISA OU RESPONSÁVEL LEGAL}

1. NOME:

DOCUMENTO DE IDENTIDADE № : SEXO : .M $\square \quad F$

DATA NASCIMENTO:

ENDEREÇO

№ APTO:

BAIRRO: CIDADE

CEP: ..TELEFONE:DDD ...)

2.RESPONSÁVEL LEGAL

NATUREZA (grau de parentesco, tutor, curador etc.)

DOCUMENTO DE IDENTIDADE : SEXO: $M \square \quad F$ DATA NASCIMENTO:

ENDEREÇO: № APTO:

BAIRRO: CIDADE:

CEP: TELEFONE: DDD

\section{DADOS SOBRE A PESQUISA}

1. TÍTULO DO PROTOCOLO DE PESQUISA

DETECÇÃO DE DNA DE MYCOBACTERIUM TUBERCULOSIS EM AMOSTRAS DE LIQUOR NO DIAGNÓSTICO E SEGUIMENTO DE PACIENTES COM MENINGITE TUBERCULOSA

PESQUISADOR : FELIPE AUGUSTO SOUZA GUALBERTO

CARGO/FUNÇÃO: MESTRANDO INSCRIÇÃO CONSELHO REGIONAL № 126721 UNIDADE DO HCFMUSP: DEPARTAMENTO DE MOLÉSTIAS INFECCIOSAS E PARASITÁRIAS 3. AVALIAÇÃO DO RISCO DA PESQUISA:

$$
\begin{array}{cc}
\text { RISCO MÍNIMO X } & \text { RISCO MÉDIO } \\
\text { RISCO BAIXO } \square & \text { RISCO MAIOR }
\end{array}
$$




\section{hospital das clínicas da faculdade de medicina da UNIVERSIDADE DE SÃO PAULO-HCFMUSP}

1 - Essas informações estão sendo fornecidas para sua participação voluntária neste estudo. Estamos realizando uma pesquisa com o objetivo de conhecer melhor as ferramentas para o diagnóstico da meningite tuberculosa. Você (ou seu familiar) foi admitido neste hospital devido a suspeita dessa doença. Ela se manifesta principalmente com sinais e sintomas como dor de cabeça e na nuca, febre, convulsões, sonolência e confusão. A meningite tuberculosa requer de tratamento específico, motivo pelo qual o diagnóstico confirmatório é muito importante.

2 - O objetivo deste termo é convidá-lo (você ou seu familiar) para participar da pesquisa. Caso você ou seu familiar aceitem serão coletados dados do seu prontuário médico. Não será necessário realizar qualquer exame além daqueles utilizados habitualmente na rotina deste hospital para a investigação desta doença e que o médico que está cuidando de você já Ihe explicou que deveriam ser coletados. A única diferença com relação aos procedimentos habituais é que uma pequena quantidade do exame do líquor será encaminhada para o Instituto Adolfo Lutz onde será realizada a pesquisa da presença de material genético do agente causador da meningite tuberculosa.

3 - Os procedimentos rotineiros utilizados no diagnóstico da meningite tuberculosa incluem exames de sangue, tomografia de crânio e coleta de líquor. A coleta de sangue é realizada por punção periférica da veia do antebraço. A tomografia de crânio consiste em um exame no qual é realizada uma imagem das estruturas internas do cérebro através de raio $x$. A coleta de líquor é um procedimento no qual é realizada a punção do espaço existente entre a coluna lombar e a medula espinhal, através de uma agulha, para a retirada de uma pequena quantidade de líquido para análise laboratorial.

4 - Os desconfortos e riscos associados aos procedimentos descritos, apesar de serem eventos raros, podem ocorrer e incluem: $i$. no exame de sangue, dor no local da punção venosa e risco de sangramento; ii. na tomografia de crânio, existe o desconforto de entrar em uma cabine de pequeno tamanho por alguns minutos e o risco de reações alérgicas quando o contraste venoso é utilizado; iii. na punção de líquor, pode ocorrer dor no local da punção, sangramento, dor de cabeça e infecção.

5 - Somente no final do estudo poderemos concluir a presença de algum benefício dos exames que estamos avaliando, não existindo benefício direto decorrente da participação no estudo.

6 - Você pode optar por realizar todos os procedimentos rotineiros para a investigação de meningite tuberculosa sem participar desta pesquisa, sem ônus algum para seu acompanhamento médico e tratamento.

7 - Garantia de acesso: em qualquer etapa do estudo, você terá acesso aos profissionais responsáveis pela pesquisa para esclarecimento de eventuais dúvidas. O principal investigador é o Dr. Felipe Gualberto que pode ser encontrado no endereço Centro de 
Referência e Tratamento de DST/Aids Rua Santa Cruz, 81 - Vila Mariana. Telefone(s) 11 5087-9917 / 11 7653-0825. Se você tiver alguma consideração ou dúvida sobre a ética da pesquisa, entre em contato com o Comitê de Ética em Pesquisa (CEP) - Rua Ovídio Pires de Campos, 225 - 5o andar - tel: 3069-6442 ramais 16, 17, 18 ou 20, FAX: 30696442 ramal 26 - E-mail: cappesq@hcnet.usp.br

8 - É garantida a liberdade da retirada de consentimento a qualquer momento e deixar de participar do estudo, sem qualquer prejuízo à continuidade de seu tratamento na Instituição.

9 - Direito de confidencialidade: as informações obtidas serão analisadas em conjunto com outros pacientes, não sendo divulgada a identificação de qualquer paciente.

10 - Você poderá ter acesso aos resultados dos seus exames colhidos durante o estudo, bem como terá acesso, se assim desejar, às publicações relacionadas ao estudo.

11 - Despesas e compensações: não há despesas pessoais para o participante em qualquer fase do estudo, incluindo exames e consultas. Também não há compensação financeira relacionada à sua participação. Se existir qualquer despesa adicional, ela será absorvida pelo orçamento da pesquisa.

12 - Todas as informações coletadas serão mantidas confidencialmente e utilizadas para esta pesquisa. Os dados serão armazenados em um computador e seu nome não aparecerá em nenhuma publicação, apresentação ou documento.

Acredito ter sido suficientemente informado a respeito das informações que li ou que foram lidas para mim, descrevendo o estudo "DETECÇÃO DE DNA DE MYCOBACTERIUM TUBERCULOSIS EM AMOSTRAS DE LIQUOR NO DIAGNÓSTICO E SEGUIMENTO DE PACIENTES COM MENINGITE TUBERCULOSA"

Eu discuti com o Dr. Felipe Gualberto sobre a minha decisão em participar nesse estudo. Ficaram claros para mim quais são os propósitos do estudo, os procedimentos a serem realizados, seus desconfortos e riscos, as garantias de confidencialidade e de esclarecimentos permanentes. Ficou claro também que minha participação é isenta de despesas e que tenho garantia do acesso a tratamento hospitalar quando necessário. Concordo voluntariamente em participar deste estudo e poderei retirar o meu consentimento a qualquer momento, antes ou durante o mesmo, sem penalidades ou prejuízo ou perda de qualquer benefício que eu possa ter adquirido, ou no meu atendimento neste Serviço.

Assinatura do paciente/representante legal

Data 11 
para casos de pacientes menores de 18 anos, analfabetos, semi-analfabetos ou portadores de deficiência auditiva ou visual.

(Somente para o responsável do projeto)

Declaro que obtive de forma apropriada e voluntária o Consentimento Livre e Esclarecido deste paciente ou representante legal para a participação neste estudo. 
Anexo C

Aprovações dos Comitês de Ética em Pesquisa 


\section{SECRETARIA DE ESTADO DA SAÚDE \\ COORDENADORIA DE SERVICCOS DE SAÚDE \\ INSTITUTO DE INFECTOLOGIA EMILIO RIBAS \\ DIVISÄO CIENTIFICA \\ SERVICYO DE ENSINO E PESQUISA}

DIVISÃO CIENTÍFICA

PROTOCOLO DE PESQUISA N 52/2007

TÍTULO: "DETECÇÃO DE DNA DE MYCOBACTERIUM TUBERCULOSIS EM AMOSTRAS DE LÍQUOR NO DIAGNÓSTIICO E SEGUIMENTO DE PACIENTES COM MENINGITE TUBERCULOSA"

PESQUISADOR RESPONSÁVEL NO IIER: AUGUSTO CÉSAR P. DE OLIVEIRA

AUTOR PRINCIPAL: FELIPE AUGUSTO SOUZA GUALBERTO

COLABORADORES: JOSÉ ERNESTO VIDAL BERMUDEZ, LUCILA OKUYAMA

FUKUSAWA, MARIA GISELE GONÇALVES, CLAUDIO TAVARES SACCHI.

\section{AUTORIZAC̄̃̃O PARA INÍCIO DO ESTUDO}

Devidamente aprovado pela Comissão Científica, Comitê de Ética em Pesquisa e Diretoria Técnica de Departamento deste Instituto, o protocolo de pesquisa acima está AUTORIZADO para ter início.

Registre-se. Comunique-se.

São Paulo, 22 de novembro de 2007.

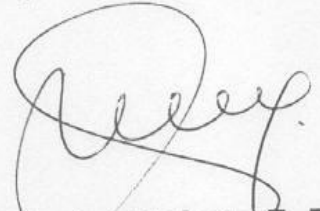

Profa. Dra. Luiza HelenatF. R. Carvalho

Chefe da Seção de Pesquisas e Trabalhos Científicos 


\section{COORDENADORIA DOS SERVIÇOS DE SAÚDE INSTITUTO DE INFECTOLOGIA "EMILIO RIBAS" \\ COMITÊ DE ÉTICA EM PESQUISA}

Av. Dr. Arnaldo, 165 - Cerqueira César - Sảo Paulo - SP

CEP: 01246-900 - TEL: 3896-1406

E-mail: comitedeetica-lier@ig.com.br

PARECER

PROTOCOLO DE PESQUISA N. ${ }^{\circ} 52 / 07$

PARECER N.O O23/2011

Data: $15 / 02 / 2011$

Título da Pesquisa: Detecção de DNA de Mycobacterium tuberculosis em amostras de líquor no diagnóstico e seguimento de pacientes com meningite tuberculosa".

Investigador Principal: Dr. Augusto César Penalva de Oliveira Autor Principal: Felipe Augusto Souza Gualberto

CONSIDERAÇÕES: O Comitê de Ética em Pesquisa toma ciência da resposta ao parecer deste CEP n. ${ }^{\circ} 017 / 2011$ datado de 09/02/2011 e Aprova o estudo e seu formulário de TCLE.

(X) APROVADO

() APROVADO COM RECOMENDAÇÕES

( ) REPROVADO

( ) COM PENDÊNCIAS- OBS.: a ausência de resposta em 60 dias, acarretará em arquivamento do processo por falta de interesse do pesquisador.
TEMÁTICA ESPECIAL
SIM
$\square$ NÃO
CONEP
I SIM $\square$ NÃO
SVS (SECRETARIA DE VIGILÂNCIA SANITÁRIA) $\square$ SIM $\square$ NÃO

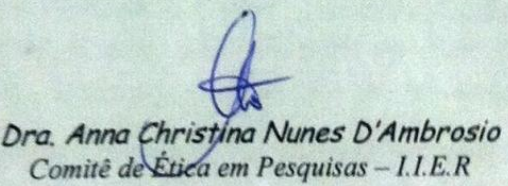




\section{COORDENADORIA DOS SERVIÇOS DE SAÚDE INSTITUTO DE INFECTOLOGIA "EMILIO RIBAS" COMITÊ DE ÉTICA EM PESQUISA}

Av. Dr. Arnaldo, 165 - Cerqueira César - São Paulo - SP

CEP: 01246-900 - TEL: $3896-1406$

E-mail: comitedeetica-iier@ig.com.br

\section{PARECER}

PROTOCOLO DE PESQUISAN. ${ }^{\circ} 52 / 07$

PARECER N.0 247/2011

Data: $26 / 8 / 2011$

Título da Pesquisa: Detecção de DNA de Mycobacterium tuberculosis em amostras de líquor no diagnóstico e seguimento de pacientes com meningite tuberculosa".

Investigador Principal: Or. Augusto César Penalva de Oliveira Autor Principal: Felipe Augusto Souza Gualberto

CONSIDERAÇÕES: 0 Comitê de Ética em Pesquisa considera respondida a pendência do parecer anterior e Aprova a solicitação da carta datada de 08/8/2011

(X) APROVADO

( ) REPROVADO

( ) COM PENDENCIAS- OBS: a ausência de resposta em 60 dias, acarretará em arquivamento do processo por falta de interesse do pesquisador.
TEMÁTICA ESPECIAL
$\square$ SIM
$\square N \tilde{A O}$
CONEP
$\square$ SIM $\square$ NÃO

SVS (SECRETARIA DE VIGILÂNCIA SANITÁRIA) $\square$ SIM

$\square \mathrm{NÃO}$

Dra. Anna Chrisfina Nunes D'Ambrosio Coordenadora do Comitê de Ética em Pesquisas - I.I.E.R 
SECRETARIA DE ESTADO DA SAÚDE Coordenadoria de Controle de Doenças Centro de Referência e Treinamento DST/Aids Rua Santa Cruz, 81 - Vila Mariana - São Paulo - SP CEP 04121-000 - Fone: 5087-9911

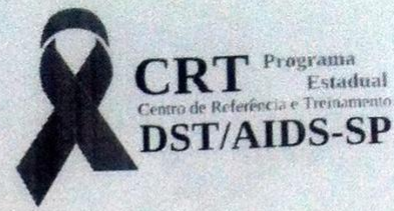

São Paulo, 21 de março 2011

Oficio CRT-DSTIAIDS - CEP n. ${ }^{0} 036 / 2011$

PROTOCOLO CEP $n^{\circ}$ 007/2011"Detecção de Mycobacterium tuberculosis em amostras de liquor no diagnóstico e seguimento de pacientes com meningite tuberculosa".

\section{Parecer: APROVADO}

Prezado Investigador,

Após a análise do documento do estudo acima referido, pelos membros deste Comitê, em reunião ordinária do dia 14 de março de 2011, foi emitido parecer APROVADO

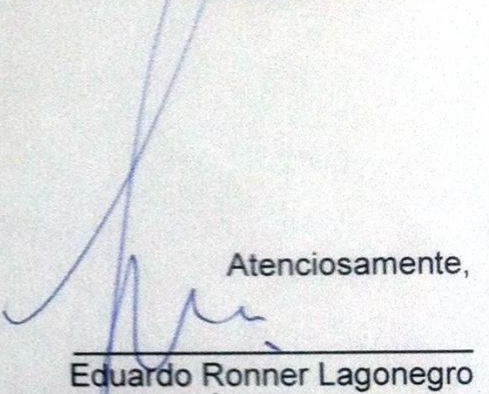

Coordenador do Comitê de Ética em Pesquisa

CRT-DSTIAIDS

IImo. Sr.

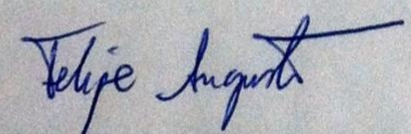

Dr Felipe Augusto Souza Gualberto

Investigador Principal 


\section{SECRETARIA DE ESTADO DA SAÚDE \\ Coordenadoria de Controle de Doenças \\ Centro de Referência e Treinamento DST/Aids \\ Centro de Referência e Treinamento Daulo - SP \\ CEP 04121-000 - Fone: 5087-9911}

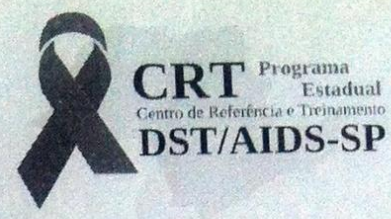

São Paulo, 27 de setembro 2011

Ofício CRT-DST/AIDS - CEP N ${ }^{\circ} 092 / 2011$

PROTOCOLO CEP N 007/2011"Detecção de Mycobacterium tuberculosis em amostras de líquor no diagnóstico e seguimento de pacientes com meningite tuberculosa".

Termo de Confidencialidade

$>$ Adendo do Projeto

\section{Parecer: APROVADO}

Prezado Investigador,

Após a análise do documento do estudo acima referido, pelos membros deste Comitê, em reunião ordinária do dia 26 de setembro de 2011, foi emitido parecer: APROVADO.

IImo. Sr.

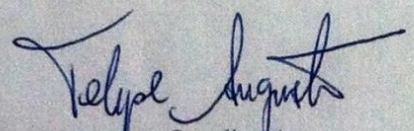

Coordenador do Comitê de Ética em Pesquisa

Dr Felipe Augusto Souza Gualberto

Investigador Principal 


\section{APROVAÇÃO}

A Comissão de Ética para Análise de Projetos de Pesquisa CAPPesa da Diretoria Clínica do Hospital das Clínicas da Faculdade de Medicina da Universidade de São Paulo, em sessão de 06/04/2011, APROVOU o Protocolo de Pesquisa $n^{\circ}$ 0151/11, intitulado: "DETECÇĀO DE DNA DE MYCOBACTERIUM TUBERCULOSIS EM AMOSTRAS DE LÍQUOR NO DIAGNÓSTICO E SEGUIMENTO DE PACIENTES CON MENINGITE TUBERCULOSA" apresentado pelo Departamento de MOLÉSTIAS INFECCIOSAS E PARASITÁRIAS, inclusive o Termo de Consentimento Livre e Esclarecido.

Cabe ao pesquisador elaborar e apresentar à CAPPesq, os relatórios parciais e final sobre a pesquisa (Resoluçăo do Conselho Nacional de Saúde n० 196, de 10/10/1996, inciso (X.2, letra "c").

Pesquisador (a) Responsável: Jose Ernesto Vidal Bermudez

Pesquisador (a) Executante: Felipe Augusto Souza Gualberto

CAPPesq, 08 de Abril de 2011

PROF. DR. EUCLIDES AYRES DE CASTILHO Coordenador

Comissāo de Ética para Análise de Projetos de Pesquisa - CAPPesq

Comissåo de Ética para Análise de Projetos de Pesquisa do HCFMUSP da Diretoria Clinica do Hospital das Clinicas da Faculdade de Medicina da Universidade de Sao Paulo Rua Ovidio Pires de Campos, 225, $5^{\circ}$ andar - CEP 05403010 - Săo Paulo - SP Fone: 0113069 6442 Fax: 01130696492 
Anexo D

Formulário de solicitação do exame de nRT-PCR no LCR

(estudo retrospectivo) 


\section{INSTITUTO ADOLFO LUTZ}

Coordenadoria de Controle de Doenças - Secretaria de Estado da Saúde

Exame para pesquisa de $M$. tuberculosis por PCR em tempo-real no Líquor

Informações para realização do exame

(Dúvidas quanto ao exame ou preenchimento da ficha? Contato com Felipe: $117653-0825)$

a. Anexar essa ficha ao pedido de SADT com todos dados preenchidos (* em campos obrigatórios)

b. Coletar $3 \mathrm{~mL}$ de LCR para o exame de PCR a ser enviado ao Instituto Adolfo Lutz

c. Enviar amostra para cultura de TB no LCR $(8 \mathrm{~mL})$ e outras investigações diagnósticas no Lab. do próprio hospital

Hospital Solicitante IIER ( ); CRT-Aids ( ) Outro ( )

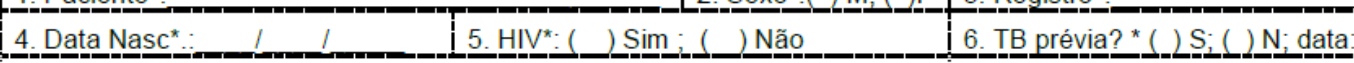

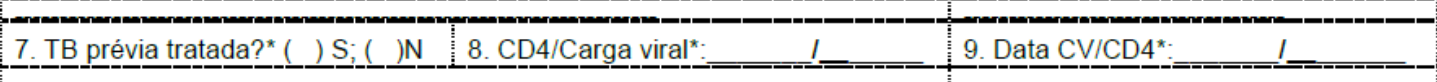

10. Sintomas*: (_) Cefaléia; (_) Confusão Mental; ( $)$ Convulsão; (_) Outro[s]

11. Dias de sintomas*: 12 . E.C. Glasgow*: Total:

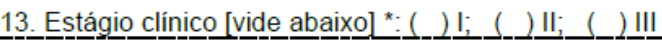

14. TC crânio alterada? * ( ) Sim; ( ) Não

15. Alteração TC *: ( ) Atrofia cerebral; ( ) Hidrocefalia; ( ) Lesão focal; ( ") Realce meníngeo;

(_) Outro[s]

16. BAAR isolado em outro sítio? * (_) Não; (_) Em andamento; (_LSim,qual? (_) Pulmão; (.) Gânglio; Outro[s]

17. Glicemia (Dextro simples) durante coleta de líquor ou glicemia do dia *: $\mathrm{mg} / \mathrm{dL}$

18. LCR células ( $\mathrm{N} \%$; $\mathrm{L} \%$; M\%; Outro [s] 18d. ADA 18a. Hemácias

18b. Proteinorraquia: 18c. Glicorraquia

Estágios Clínicos de Meningite Tuberculosa

I - Paciente lúcido, sem déficits neurológicos focais ou hidrocefalia.

II - Pacientes com letargia, confusão mental; pode apresentar déficits focais moderados, como paralisia de nervo de par craniano ou hemiparesia.

III - Doença avançada com delirium, torpor, coma, convulsões e múltiplas paralisias de pares de nervos cranianos e/ou hemiplegia. 
8. REFERÊNCIAS 
Agasino CB, Ponce de Leon A, Jasmer RM, Small PM. Epidemiology of Mycobacterium tuberculosis strains in San Francisco that do not contain IS6110. Int J Tuberc Lung Dis. 1998 Jun;2(6):518-20.

Ahuja GK, Mohan KK, Prasad K, Behari M. Diagnostic criteria for tuberculous meningitis and their validation. Tuber Lung Dis. 1994 Apr;75(2):149-52.

Andronikou S, Smith B, Hatherhill M, Douis H, Wilmshurst J. Definitive neuroradiological diagnostic features of tuberculous meningitis in children. Pediatr Radiol. 2004 Nov;34(11):876-85.

Antonucci G, Girardi E, Raviglione MC, Ippolito G. Risk factors for tuberculosis in HIV-infected persons. A prospective cohort study. The Gruppo Italiano di Studio Tubercolosi e AIDS (GISTA). JAMA. 1995 Jul 12;274(2):143-8.

Appleman ME, Marshall DW, Brey RL, Houk RW, Beatty DC, Winn RE, et al. Cerebrospinal fluid abnormalities in patients without AIDS who are seropositive for the human immunodeficiency virus. J Infect Dis. $1988 \mathrm{Jul}$;158(1):193-9.

Azevedo LC, Toscano CM, Bierrenbach AL. Bacterial Meningitis in Brazil: Baseline Epidemiologic Assessment of the Decade Prior to the Introduction of Pneumococcal and Meningococcal Vaccines. PLoS One. 2013;8(6):e64524. doi:10.1371/journal.pone.0064524

Bahls F, Sumi SM. Cryptococcal meningitis and cerebral toxoplasmosis in a patient with acquired immune deficiency syndrome. J Neurol Neurosurg Psychiatry. 1986 Mar;49(3):328-30.

Berenguer J, Moreno S, Laguna F, Vicente T, Adrados M, Ortega A, et al. Tuberculous meningitis in patients infected with the human immunodeficiency virus. N Engl J Med. 1992 Mar 5;326(10):668-72.

Bernaerts A, Vanhoenacker FM, Parizel PM, Van Goethem JW, Van Altena R, Laridon $A$, et al. Tuberculosis of the central nervous system: overview of neuroradiological findings. Eur Radiol. 2003 Aug;13(8):1876-90. 
Bhigjee Al, Padayachee R, Paruk H, Hallwirth-Pillay KD, Marais S, Connoly C. Diagnosis of tuberculous meningitis: clinical and laboratory parameters. Int $\mathrm{J}$ Infect Dis. 2007 Jul;11(4):348-54.

Bishburg E, Sunderam G, Reichman LB, Kapila R. Central nervous system tuberculosis with the acquired immunodeficiency syndrome and its related complex. Ann Intern Med. 1986 Aug;105(2):210-3.

Bonington A, Strang JI, Klapper PE, Hood SV, Parish A, Swift PJ, et al. TB PCR in the early diagnosis of tuberculous meningitis: evaluation of the Roche semiautomated COBAS Amplicor MTB test with reference to the manual Amplicor MTB PCR test. Tuber Lung Dis. 2000;80(4-5):191-6.

Bonington A, Strang JI, Klapper PE, Hood SV, Rubombora W, Penny M, et al. Use of Roche AMPLICOR Mycobacterium tuberculosis PCR in early diagnosis of tuberculous meningitis. J Clin Microbiol. 1998 May;36(5):1251-4.

Bossuyt PM, Reitsma JB, Bruns DE, Gatsonis CA, Glasziou PP, Irwig LM, et al. The STARD statement for reporting studies of diagnostic accuracy: explanation and elaboration. Clin Chem. 2003 Jan;49(1):7-18.

Brancusi F, Farrar J, Heemskerk D. Tuberculous meningitis in adults: a review of a decade of developments focusing on prognostic factors for outcome. Future Microbiol. 2012 Sep;7:1101-16.

Brasil. Ministério da saúde. Casos de meningite por tuberculose por faixa etária entre 1990 e 2000. [Acessado dia 2 de outubro de 2009]. Disponível em: http://portal.saude.gov.br/portal/arquivos/pdf/meningitepdf.pdf.

Brasil. Ministério da Saúde. Secretaria de Vigilância em Saúde. Boletim Epidemiológico. Volume 44 (2), 2013.

Brasil. Ministério da Saúde. Secretaria de Vigilância em Saúde. Departamento de Vigilância Epidemiológica. Manual de recomendações para o controle da tuberculose no Brasil / Ministério da Saúde, Secretaria de Vigilância em Saúde, Departamento de Vigilância Epidemiológica. - Brasília: Ministério da Saúde, 
2011.

Brasil. Programa Nacional de Controle da Tuberculose/Secretaria de Vigilância em Saúde/Ministério da Saúde (PNCT/SVS/M). Nota técnica sobre as mudanças no tratamento da tuberculose no Brasil para adultos e adolescentes, 2009. [Acessado dia 2 de outubro de 2009]. Disponível em: http://portal.saude.gov.br/portal/arquivos/pdf/nota_tecnica_versao_28_de_agost o_v_5.pdf.

Brienze VM, Tonon AP, Pereira FJ, Liso E, Tognola WA, dos Santos MA, et al. Low sensitivity of polymerase chain reaction for diagnosis of tuberculous meningitis in southeastern Brazil. Rev Soc Bras Med Trop. 2001 JulAug;34(4):389-93.

British Medical Research Council (BMRC). STREPTOMYCIN treatment of tuberculous meningitis. Lancet. 1948 Apr 17;1(6503):582-96.

Caws M, Wilson SM, Clough C, Drobniewski F. Role of IS6110-targeted PCR, culture, biochemical, clinical, and immunological criteria for diagnosis of tuberculous meningitis. J Clin Microbiol. 2000 Sep;38(9):3150-5.

Cecchini D, Ambrosioni J, Brezzo C, Corti M, Rybko A, Perez M, et al. Tuberculous meningitis in HIV-infected patients: drug susceptibility and clinical outcome. AIDS. 2007 Jan 30;21(3):373-4.

Cecchini D, Ambrosioni J, Brezzo C, Corti M, Rybko A, Perez M, et al. Tuberculous meningitis in HIV-infected and non-infected patients: comparison of cerebrospinal fluid findings. Int J Tuberc Lung Dis. 2009 Feb;13(2):269-71.

Center for Disease Control (CDC). National action plan to combat multidrugresistant tuberculosis. MMWR Recomm Rep. 1992 Jun 19;41(RR-11):5-48.

Centro de Vigilância Epidemiológica "Prof. Alexandre Vranjac" (CVE/SP). Divisão de Tuberculose. Sala de Situação de Tuberculose do Estado de São Paulo. <http://tuberculosesp.cealag.com.br/> [Acessado em 15 de novembro de 2013] 
Chan KH, Cheung RT, Lee R, Mak W, Ho SL. Cerebral infarcts complicating tuberculous meningitis. Cerebrovasc Dis. 2005;19(6):391-5.

Chandramuki A, Lyashchenko K, Kumari HB, Khanna N, Brusasca P, GourieDevi $M$, et al. Detection of antibody to Mycobacterium tuberculosis protein antigens in the cerebrospinal fluid of patients with tuberculous meningitis. $J$ Infect Dis. 2002 Sep 1;186(5):678-83.

Chauhan DS, Sharma VD, Parashar D, Chauhan A, Singh D, Singh HB, et al. Molecular typing of Mycobacterium tuberculosis isolates from different parts of India based on IS6110 element polymorphism using RFLP analysis. Indian J Med Res. 2007 Apr;125(4):577-81.

Chedore P, Jamieson FB. Rapid molecular diagnosis of tuberculous meningitis using the Gen-probe Amplified Mycobacterium Tuberculosis direct test in a large Canadian public health laboratory. Int J Tuberc Lung Dis. 2002 Oct;6(10):913-9.

Chen P, Shi M, Feng GD, Liu JY, Wang BJ, Shi XD, et al. A highly efficient Ziehl-Neelsen stain: identifying de novo intracellular Mycobacterium tuberculosis and improving detection of extracellular $M$. tuberculosis in cerebrospinal fluid. J Clin Microbiol. 2012 Apr;50(4):1166-70.

Chimelli L, Rosemberg S, Hahn MD, Lopes MB, Netto MB. Pathology of the central nervous system in patients infected with the human immunodeficiency virus (HIV): a report of 252 autopsy cases from Brazil. Neuropathol Appl Neurobiol. 1992 Oct;18(5):478-88.

Cole ST, Brosch R, Parkhill J, Garnier T, Churcher C, Harris D, et al. Deciphering the biology of Mycobacterium tuberculosis from the complete genome sequence. Nature. 1998 Jun 11;393(6685):537-44.

Comstock GW. Epidemiology of tuberculosis. Am Rev Respir Dis. 1982 Mar;125(3 Pt 2):8-15.

Corbett EL, Marston B, Churchyard GJ, De Cock KM. Tuberculosis in sub- 
Saharan Africa: opportunities, challenges, and change in the era of antiretroviral treatment. Lancet. 2006 Mar 18;367(9514):926-37.

Corbett EL, Watt CJ, Walker N, Maher D, Williams BG, Raviglione MC, et al. The growing burden of tuberculosis: global trends and interactions with the HIV epidemic. Arch Intern Med. 2003 May 12;163(9):1009-21.

Croda MG, Vidal JE, Hernandez AV, Dal Molin T, Gualberto FA, de Oliveira AC. Tuberculous meningitis in HIV-infected patients in Brazil: clinical and laboratory characteristics and factors associated with mortality. Int J Infect Dis. 2010 Jul;14(7):e586-91.

Dar L, Sharma SK, Bhanu NV, Broor S, Chakraborty M, Pande JN, et al. Diagnosis of pulmonary tuberculosis by polymerase chain reaction for MPB64 gene: an evaluation in a blind study. Indian J Chest Dis Allied Sci. 1998 JanMar;40(1):5-16.

Das S, Paramasivan CN, Lowrie DB, Prabhakar R, Narayanan PR. IS6110 restriction fragment length polymorphism typing of clinical isolates of Mycobacterium tuberculosis from patients with pulmonary tuberculosis in Madras, south India. Tuber Lung Dis. 1995 Dec;76(6):550-4.

Dastur DK, Manghani DK, Udani PM. Pathology and pathogenetic mechanisms in neurotuberculosis. Radiol Clin North Am. 1995 Jul;33(4):733-52.

Demerdash, HAME. A Simple and Inexpensive Procedure for Chromosomal DNA Extraction from Streptococcus thermophilus Strains. MEJSR 11 (1): 13-18, 2012

Desai D, Nataraj G, Kulkarni S, Bichile L, Mehta P, Baveja S, et al. Utility of the polymerase chain reaction in the diagnosis of tuberculous meningitis. Res Microbiol. 2006 Dec;157(10):967-70.

Deshpande PS, Kashyap RS, Ramteke SS, Nagdev KJ, Purohit HJ, Taori GM, et al. Evaluation of the IS6110 PCR assay for the rapid diagnosis of tuberculous meningitis. Cerebrospinal Fluid Res. 2007;4:10. 
Dinnes J, Deeks J, Kunst H, Gibson A, Cummins E, Waugh N, et al. A systematic review of rapid diagnostic tests for the detection of tuberculosis infection. Health Technol Assess. 2007 Jan;11(3):1-196.

Donald PR, Schaaf HS, Schoeman JF. Tuberculous meningitis and miliary tuberculosis: the Rich focus revisited. J Infect. 2005 Apr;50(3):193-5.

Donald PR, Victor TC, Jordaan AM, Schoeman JF, van Helden PD. Polymerase chain reaction in the diagnosis of tuberculous meningitis. Scand $J$ Infect Dis. 1993;25(5):613-7.

Dora JM, Geib G, Chakr R, Paris F, Mombach AB, Lutz L, Souza CF, Goldani LZ. Polymerase chain reaction as a useful and simple tool for rapid diagnosis of tuberculous meningitis in a Brazilian tertiary care hospital. Braz J Infect Dis. 2008 Jun;12(3):245-7.

Dos Santos GP, Skraba I, Oliveira D, Lima AA, de Melo MM, Kmetzsch Cl, et al. Enterovirus meningitis in Brazil, 1998-2003. J Med Virol. 2006 Jan;78(1):98104.

Dube MP, Holtom PD, Larsen RA. Tuberculous meningitis in patients with and without human immunodeficiency virus infection. Am J Med. 1992 Nov;93(5):520-4.

Ducomble T, Tolksdorf K, Karagiannis I, Hauer B, Brodhun B, Haas W, et al. The burden of extrapulmonary and meningitis tuberculosis: an investigation of national surveillance data, Germany, 2002 to 2009. Euro Surveill. 2013;18(12).

Emery SL, Erdman DD, Bowen MD, Newton BR, Winchell JM, Meyer RF, et al. Real-time reverse transcription-polymerase chain reaction assay for SARSassociated coronavirus. Emerg Infect Dis. 2004 Feb;10(2):311-6.

Enberg G M, Quezada B Mde L, de Toro V C, Fuenzalida L L. Tuberculous meningitis in adults: review of 53 cases.Rev Chilena Infectol. 2006 Jun;23(2):134-9. 
Espy MJ, Uhl JR, Sloan LM, Buckwalter SP, Jones MF, Vetter EA, et al. Realtime PCR in clinical microbiology: applications for routine laboratory testing. Clin Microbiol Rev. 2006 Jan;19(1):165-256.

Fallon RJ, Kennedy DH. Rapid diagnosis of tuberculous meningitis. J Infect. 1993 Mar;26(2):226.

Fanning A. Tuberculosis: 6. Extrapulmonary disease. CMAJ. 1999 Jun 1;160(11):1597-603.

Fitzgerald D, Haas DW. Mycobacterium tuberculosis. In: Mandell GL, Bennett JE, Dolin R: Principles and Practice of Infectious Diseases, 6th ed., Churchill Livingstone: Elsevier: 2005; v. 2, p. $2853-2885$.

Foerster BR, Thurnher MM, Malani PN, Petrou M, Carets-Zumelzu F, Sundgren PC. Intracranial infections: clinical and imaging characteristics. Acta Radiol. 2007 Oct;48(8):875-93.

Folgueira L, Delgado R, Palenque E, Noriega AR. Polymerase chain reaction for rapid diagnosis of tuberculous meningitis in AIDS patients. Neurology. 1994 Jul;44(7):1336-8.

Garcia-Rodriguez JF, Alvarez-Diaz H, Lorenzo-Garcia MV, Marino-Callejo A, Fernandez-Rial A, Sesma-Sanchez P. Extrapulmonary tuberculosis: epidemiology and risk factors. Enferm Infecc Microbiol Clin. 2011 AugSep;29(7):502-9.

Garg RK, Sinha MK. Tuberculous meningitis in patients infected with human immunodeficiency virus. J Neurol. 2011 Jan;258(1):3-13.

Garg RK. Tuberculosis of the central nervous system. Postgrad Med J. 1999 Mar;75(881):133-40.

Gascoyne-Binzi DM, Hawkey PM. False negative polymerase chain reaction on cerebrospinal fluid samples in tuberculous meningitis. J Neurol Neurosurg Psychiatry. 1999 Aug;67(2):250. 
Golden MP, Vikram HR. Extrapulmonary tuberculosis: an overview. Am Fam Physician. 2005 Nov 1;72(9):1761-8.

Gomez-Aranda F, Lopez-Dominguez JM, Munoz Malaga A, Blanco Ollero A. Meningitis simultaneously due to Cryptococcus neoformans and Mycobacterium tuberculosis. Clin Infect Dis. 1993 Apr;16(4):588-9.

Gonçalves, Maria Gisele. Perfil mutacional dos genes responsáveis pela resistência de Mycobacterium tuberculosis a rifampicina (rpoB) e isonizida (katG e inhA) em cepas isoladas no Estado de São Paulo e avaliação do uso da PCR em tempo real para a detecção rápida destas mutações [Dissertação de Mestrado]. Programa de Pós-Graduação em Ciências da Coordenadoria de Controle de Doenças da Secretaria de Estado da Saúde de São Paulo.

Green PH. Tubercular meningitis. Lancet 1836; 2: 232-35.

Hakim JG, Gangaidzo IT, Heyderman RS, Mielke J, Mushangi E, Taziwa A, et al. Impact of HIV infection on meningitis in Harare, Zimbabwe: a prospective study of 406 predominantly adult patients. AIDS. $2000 \mathrm{Jul}$ 7;14(10):1401-7.

Haldar S, Sankhyan N, Sharma N, Bansal A, Jain V, Gupta VK, et al. Detection of Mycobacterium tuberculosis GlcB or HspX Antigens or devR DNA Impacts the Rapid Diagnosis of Tuberculous Meningitis in Children. PLoS One. 2012;7(9):e44630.

Haldar S, Sharma N, Gupta VK, Tyagi JS. Efficient diagnosis of tuberculous meningitis by detection of Mycobacterium tuberculosis DNA in cerebrospinal fluid filtrates using PCR. J Med Microbiol. 2009 May;58(Pt 5):616-24.

Heringer RR, Fernandes LE, Goncalves RR, Puccioni-Sohler M. [Location of the lesion and the cerebrospinal fluid findings in tuberculous meningitis: differences in the lumbar, cisternal and ventricular compartiments.]. Arq Neuropsiquiatr. 2005 Jun;63(2B):543-7.

Hermans PW, van Soolingen D, Dale JW, Schuitema AR, McAdam RA, Catty D, et al. Insertion element IS986 from Mycobacterium tuberculosis: a useful tool 
for diagnosis and epidemiology of tuberculosis. J Clin Microbiol. 1990 Sep;28(9):2051-8.

Hinrichsen SL, Ataíde Junior L, Travassos F, Travassos P, Alburquerque E, Moura L, Arraes LC, Rocha LV, Amorim MR, Luz LM, Braga A. Cerebrospinal fluid in 50 AIDS patients. Arq Neuropsiquiatr. 1996 Jun;54(2):227-31.

Ho Dang Trung N, Le Thi Phuong T, Wolbers M, Nguyen Van Minh H, Nguyen Thanh V, Van MP, et al. Aetiologies of central nervous system infection in Viet Nam: a prospective provincial hospital-based descriptive surveillance study. PLoS One. 2012;7(5):e37825.

Ho J, Marais BJ, Gilbert GL, Ralph AP. Ho J, Marais BJ, Gilbert GL, Ralph AP. Diagnosing tuberculous meningitis - have we made any progress? Trop Med Int Health. 2013 Jun;18(6):783-93.? Trop Med Int Health. 2013 Jun;18(6):783-93.

Hollander H, McGuire D, Burack JH. Diagnostic lumbar puncture in HIV-infected patients: analysis of 138 cases. Am J Med. 1994 Mar;96(3):223-8.

Hollander H, Stringari S. Human immunodeficiency virus-associated meningitis. Clinical course and correlations. Am J Med. 1987 Nov;83(5):813-6.

Hosoglu S, Ayaz C, Geyik MF, Kokoglu OF, Ceviz A. Tuberculous meningitis in adults: an eleven-year review. Int J Tuberc Lung Dis. 1998 Jul;2(7):553-7.

Hristea A, Olaru ID. Applying a consensus case definition to patients with confirmed tuberculous meningitis. Int J Infect Dis. 2012 Oct;16(10):e758-9.

Huang HJ, Xiang DR, Sheng JF, Li J, Pan XP, Yu HY, et al. rpoB nested PCR and sequencing for the early diagnosis of tuberculous meningitis and rifampicin resistance. Int J Tuberc Lung Dis. 2009 Jun;13(6):749-54.

Jongeling AC, Pisapia D. Pearls and Oy-sters: Tuberculous meningitis: Not a diagnosis of exclusion. Neurology. 2013 Jan 22;80(4):e36-9.

Kaneko K, Onodera O, Miyatake T, Tsuji S. Rapid diagnosis of tuberculous 
meningitis by polymerase chain reaction (PCR). Neurology. 1990 Oct;40(10):1617-8.

Karstaedt AS, Valtchanova S, Barriere R, Crewe-Brown HH. Tuberculous meningitis in South African urban adults. QJM. 1998 Nov;91(11):743-7.

Katrak SM, Shembalkar PK, Bijwe SR, Bhandarkar LD. The clinical, radiological and pathological profile of tuberculous meningitis in patients with and without human immunodeficiency virus infection. J Neurol Sci. 2000 Dec 1;181(12):118-26.

Katti MK. Pathogenesis, diagnosis, treatment, and outcome aspects of cerebral tuberculosis. Med Sci Monit. 2004 Sep;10(9):RA215-29.

Kennedy DH, Fallon RJ. Tuberculous meningitis. JAMA. 1979 Jan 19;241(3):264-8.

Kent L, McHugh TD, Billington O, Dale JW, Gillespie SH. Demonstration of homology between IS6110 of Mycobacterium tuberculosis and DNAs of other Mycobacterium spp.? J Clin Microbiol. 1995 Sep;33(9):2290-3.

Kent SJ, Crowe SM, Yung A, Lucas CR, Mijch AM. Tuberculous meningitis: a 30-year review. Clin Infect Dis. 1993 Dec;17(6):987-94.

Kibayashi K, Ng'walali PM, Mbonde MP, Makata AM, Mwakagile D, Harada S, et al. Neuropathology of human immunodeficiency virus 1 infection. Significance of studying in forensic autopsy cases at Dar es Salaam, Tanzania. Arch Pathol Lab Med. 1999 Jun;123(6):519-23.

Kirschner P, Rosenau J, Springer B, Teschner K, Feldmann K, Bottger EC. Diagnosis of mycobacterial infections by nucleic acid amplification: 18-month prospective study. J Clin Microbiol. 1996 Feb;34(2):304-12.

Kox LF, Kuijper S, Kolk AH. Early diagnosis of tuberculous meningitis by polymerase chain reaction. Neurology. 1995 Dec;45(12):2228-32. 
Kulkarni SP, Jaleel MA, Kadival GV. Evaluation of an in-house-developed PCR for the diagnosis of tuberculous meningitis in Indian children. J Med Microbiol. 2005 Apr;54(Pt 4):369-73.

Kusum S, Aman S, Pallab R, Kumar SS, Manish M, Sudesh P, et al. Multiplex PCR for rapid diagnosis of tuberculous meningitis. J Neurol. 2011 Oct;258(10):1781-7.

Laguna F, Adrados M, Ortega A, Gonzalez-Lahoz JM. Tuberculous meningitis with acellular cerebrospinal fluid in AIDS patients. AIDS. 1992 Oct;6(10):1165-7.

Landis JR, Koch GG. The measurement of observer agreement for categorical data. Biometrics. 1977 Mar;33(1):159-74.

Lanjewar DN, Jain PP, Shetty CR. Profile of central nervous system pathology in patients with AIDS: an autopsy study from India. AIDS. 1998 Feb 12;12(3):309-13.

Lee BW, Tan JA, Wong SC, Tan CB, Yap HK, Low PS, et al. DNA amplification by the polymerase chain reaction for the rapid diagnosis of tuberculous meningitis. Comparison of protocols involving three mycobacterial DNA sequences, IS6110, 65 kDa antigen, and MPB64. J Neurol Sci. 1994 May;123(1-2):173-9.

Leeds IL, Magee MJ, Kurbatova EV, del Rio C, Blumberg HM, Leonard MK, et al. Site of extrapulmonary tuberculosis is associated with HIV infection. Clin Infect Dis. 2012 Jul;55(1):75-81.

Leitritz L, Schubert S, Bucherl B, Masch A, Heesemann J, Roggenkamp A. Evaluation of BACTEC MGIT 960 and BACTEC 460TB systems for recovery of mycobacteria from clinical specimens of a university hospital with low incidence of tuberculosis. J Clin Microbiol. 2001 Oct;39(10):3764-7.

Leonard JM, Des Prez RM. Tuberculous meningitis. Infect Dis Clin North Am. 1990 Dec;4(4):769-87. 
Liu PY, Shi ZY, Lau YJ, Hu BS. Rapid diagnosis of tuberculous meningitis by a simplified nested amplification protocol. Neurology. 1994 Jun;44(6):1161-4.

Livramento JA, Machado LR, Spina-França A. Cerebrospinal fluid abnormalities in 170 cases of AIDS. Arq Neuropsiquiatr. 1989 Sep;47(3):326-31.

Lonnroth K, Raviglione M. Global epidemiology of tuberculosis: prospects for control. Semin Respir Crit Care Med. 2008 Oct;29(5):481-91.

Lucas SB, Hounnou A, Peacock C, Beaumel A, Djomand G, N'Gbichi JM, et al. The mortality and pathology of HIV infection in a west African city. AIDS. 1993 Dec;7(12):1569-79.

Luma HN, Tchaleu BC, Doualla MS, Temfack E, Sopouassi VN, Mapoure YN, et al. HIV-associated sensory neuropathy in HIV-1 infected patients at the Douala General Hospital in Cameroon: a cross-sectional study. AIDS Res Ther. 2012;9(1):35.

Marais S, Pepper DJ, Marais BJ, Torok ME. HIV-associated tuberculous meningitis--diagnostic and therapeutic challenges. Tuberculosis (Edinb). 2010a Nov;90(6):367-74.

Marais S, Thwaites G, Schoeman JF, Torok ME, Misra UK, Prasad K, et al. Tuberculous meningitis: a uniform case definition for use in clinical research. Lancet Infect Dis. 2010b Nov;10(11):803-12.

Martins LC, Paschoal IA, Von Nowakonski A, Silva SA, Costa FF, Ward LS. Nested-PCR using MPB64 fragment improves the diagnosis of pleural and meningeal tuberculosis. Rev Soc Bras Med Trop. 2000 May-Jun;33(3):253-7.

McMurtray A, Nakamoto B, Shikuma C, Valcour V. Cortical atrophy and white matter hyperintensities in HIV: the Hawaii Aging with HIV Cohort Study. J Stroke Cerebrovasc Dis. 2008 Jul-Aug;17(4):212-7.

Melzer M, Brown TJ, Flood J, Lacey S, Bagg LR. False negative polymerase chain reaction on cerebrospinal fluid samples in tuberculous meningitis 
established by culture. J Neurol Neurosurg Psychiatry. 1999 Aug;67(2):249-50.

Narayanan S, Parandaman V, Narayanan PR, Venkatesan P, Girish C, Mahadevan S, Rajajee S. Evaluation of PCR using TRC(4) and IS6110 primers in detection of tuberculous meningitis. J Clin Microbiol. 2001 May;39(5):2006-8.

Naughten E, Weindling AM, Newton R, Bower BD. Tuberculous meningitis in children. Recent experience in two English centres. Lancet. 1981 Oct $31 ; 2(8253): 973-5$.

Ogawa SK, Smith MA, Brennessel DJ, Lowy FD. Tuberculous meningitis in an urban medical center. Medicine (Baltimore). 1987 Jul;66(4):317-26.

Oliveira JF, Greco DB, Oliveira GC, Christo PP, Guimaraes MD, Oliveira RC. Neurological disease in HIV-infected patients in the era of highly active antiretroviral treatment: a Brazilian experience. Rev Soc Bras Med Trop. 2006 Mar-Apr;39(2):146-51.

Pai M, Flores LL, Pai N, Hubbard A, Riley LW, Colford JM, Jr. Diagnostic accuracy of nucleic acid amplification tests for tuberculous meningitis: a systematic review and meta-analysis. Lancet Infect Dis. 2003 Oct;3(10):633-43.

Patel VB, Theron G, Lenders L, Matinyena B, Connolly C, Singh R, et al. Diagnostic accuracy of quantitative PCR (Xpert MTB/RIF) for tuberculous meningitis in a high burden setting: a prospective study. PLoS Med. 2013 Oct;10(10):e1001536.

Pehlivanoglu F, Yasar KK, Sengoz G. Tuberculous meningitis in adults: a review of 160 cases. ScientificWorldJournal. 2012;2012:169028.

Peto HM, Pratt RH, Harrington TA, LoBue PA, Armstrong LR. Epidemiology of extrapulmonary tuberculosis in the United States, 1993-2006. Clin Infect Dis. 2009 Nov 1;49(9):1350-7.

Phypers M, Harris T, Power C. CNS tuberculosis: a longitudinal analysis of epidemiological and clinical features. Int J Tuberc Lung Dis. 2006 Jan;10(1):99- 
103.

Principi N, Esposito S. Diagnosis and therapy of tuberculous meningitis in children. Tuberculosis (Edinb). 2012 Sep;92(5):377-83.

Puccioni-Sohler M, Brandao CO. Factors associated to the positive cerebrospinal fluid culture in the tuberculous meningitis. Arq Neuropsiquiatr. 2007 Mar;65(1):48-53.

Rafi W, Venkataswamy MM, Ravi V, Chandramuki A. Rapid diagnosis of tuberculous meningitis: a comparative evaluation of in-house PCR assays involving three mycobacterial DNA sequences, IS6110, MPB-64 and $65 \mathrm{kDa}$ antigen. J Neurol Sci. 2007 Jan 31;252(2):163-8.

Rana FS, Hawken MP, Mwachari C, Bhatt SM, Abdullah F, Ng'ang'a LW, et al. Autopsy study of HIV-1-positive and HIV-1-negative adult medical patients in Nairobi, Kenya. J Acquir Immune Defic Syndr. 2000 May 1;24(1):23-9.

Rich, AR, McCordock, HA. Pathogenesis of tuberculous meningitis. Bull Johns Hopkins Hosp. 1933: 52:5.

Sakula A. Robert Koch: centenary of the discovery of the tubercle bacillus, 1882. Thorax. 1982 Apr;37(4):246-51.

Sandgren A, Hollo V, van der Werf MJ. Extrapulmonary tuberculosis in the European Union and European Economic Area, 2002 to 2011. Euro Surveill. 2013;18(12):pii=20431. Disponível em: <http://www.eurosurveillance.org/ViewArticle.aspx?Articleld=20431>

Sankar S, Kuppanan S, Balakrishnan B, Nandagopal B. Analysis of sequence diversity among IS6110 sequence of Mycobacterium tuberculosis: possible implications for PCR based detection. Bioinformation. 2011;6(7):283-5.

Scarpellini P, Racca S, Cinque P, Delfanti F, Gianotti N, Terreni MR, et al. Nested polymerase chain reaction for diagnosis and monitoring treatment response in AIDS patients with tuberculous meningitis. AIDS. 1995 
Aug;9(8):895-900.

Schunemann HJ, Oxman AD, Brozek J, Glasziou P, Jaeschke R, Vist GE, et al. Grading quality of evidence and strength of recommendations for diagnostic tests and strategies. BMJ. 2008 May 17;336(7653):1106-10.

Schutte CM. Clinical, cerebrospinal fluid and pathological findings and outcomes in HIV-positive and HIV-negative patients with tuberculous meningitis. Infection. 2001 Aug;29(4):213-7.

Shankar P, Manjunath N, Mohan KK, Prasad K, Behari M, Shriniwas, et al. Rapid diagnosis of tuberculous meningitis by polymerase chain reaction. Lancet. 1991 Jan 5;337(8732):5-7.

Silber E, Sonnenberg P, Koornhof HJ, Morris L, Saffer D. Dual infective pathology in patients with cryptococcal meningitis. Neurology. 1998 Oct;51(4):1213-5.

Sistema de Informação de Agravos de Notificação (SINAN), 2013. DATASUS. <http://dtr2004.saude.gov.br/sinanweb/> [Acessado em novembro de 2013].

Stauffer F, Haber H, Rieger A, Mutschlechner R, Hasenberger P, Tevere VJ, et al. Genus level identification of mycobacteria from clinical specimens by using an easy-to-handle Mycobacterium-specific PCR assay. J Clin Microbiol. 1998 Mar;36(3):614-7.

Stewart SM. The bacteriological diagnosis of tuberculous meningitis. J Clin Pathol. 1953 Aug;6(3):241-2.

Sugden B, De Troy B, Roberts RJ, Sambrook J. Agarose slab-gel electrophoresis equipment. Anal Biochem. 1975 Sep;68(1):36-46

Takahashi T, Nakayama T, Tamura M, Ogawa K, Tsuda H, Morita A, et al. Nested polymerase chain reaction for assessing the clinical course of tuberculous meningitis. Neurology. 2005 May 24;64(10):1789-93. 
Takahashi T, Nakayama T. Novel technique of quantitative nested real-time PCR assay for Mycobacterium tuberculosis DNA. J Clin Microbiol. 2006 Mar;44(3):1029-39.

Takahashi T, Tamura M, Takahashi SN, Matsumoto K, Sawada S, Yokoyama E, et al. Quantitative nested real-time PCR assay for assessing the clinical course of tuberculous meningitis. J Neurol Sci. 2007 Apr 15;255(1-2):69-76.

Takahashi T, Tamura M, Takasu T. The PCR-Based Diagnosis of Central Nervous System Tuberculosis: Up to Date. Tuberc Res Treat. 2012;2012:831292.

Tan IL, Smith BR, von Geldern G, Mateen FJ, McArthur JC. HIV-associated opportunistic infections of the CNS. Lancet Neurol. 2012 Jul;11(7):605-17.

Telenti A, Imboden P, Marchesi F, Lowrie D, Cole S, Colston MJ, et al. Detection of rifampicin-resistance mutations in Mycobacterium tuberculosis. Lancet. 1993 Mar 13;341(8846):647-50.

Thakur R, Goyal R, Sarma S. Laboratory diagnosis of tuberculous meningitis is there a scope for further improvement? J Lab Physicians. 2010 Jan;2(1):21-4.

Thakur R, Sarma S, Goyal R. Comparison of DNA Extraction Protocols for Mycobacterium Tuberculosis in Diagnosis of Tuberculous Meningitis by Realtime Polymerase Chain Reaction. J Glob Infect Dis. 2011 Oct;3(4):353-6.

Thoa N, et al. The influence of HIV infection on clinical presentation, response to treatment, and outcome in adults with Tuberculous meningitis. J Infect Dis. 2005 Dec 15;192(12):2134-41.

Thomsen VO, Kok-Jensen A, Buser M, Philippi-Schulz S, Burkardt HJ. Monitoring treatment of patients with pulmonary tuberculosis: can PCR be applied? J Clin Microbiol. 1999 Nov;37(11):3601-7.

Thwaites G, Fisher M, Hemingway C, Scott G, Solomon T, Innes J. British Infection Society guidelines for the diagnosis and treatment of tuberculosis of 
the central nervous system in adults and children. J Infect. 2009 Sep;59(3):16787.

Thwaites GE, Chau TT, Farrar JJ. Improving the bacteriological diagnosis of tuberculous meningitis. J Clin Microbiol. 2004a Jan;42(1):378-9.

Thwaites GE, Chau TT, Stepniewska K, Phu NH, Chuong LV, Sinh DX, et al. Diagnosis of adult tuberculous meningitis by use of clinical and laboratory features. Lancet. 2002 Oct 26;360(9342):1287-92.

Thwaites GE, Duc Bang N, Huy Dung N, Thi Quy H, Thi Tuong Oanh D, Thi Cam Thoa $\mathrm{N}$, et al. The influence of HIV infection on clinical presentation, response to treatment, and outcome in adults with Tuberculous meningitis. $J$ Infect Dis. 2005b Dec 15;192(12):2134-41.

Thwaites GE, Nguyen DB, Nguyen HD, Hoang TQ, Do TT, Nguyen TC, et al. Dexamethasone for the treatment of tuberculous meningitis in adolescents and adults. N Engl J Med. 2004b Oct 21;351(17):1741-51.

Thwaites GE, Simmons CP, Than Ha Quyen N, Thi Hong Chau T, Phuong Mai $\mathrm{P}$, Thi Dung N, et al. Pathophysiology and prognosis in vietnamese adults with tuberculous meningitis. J Infect Dis. 2003 Oct 15;188(8):1105-15.

Thwaites GE, Tran TH. Tuberculous meningitis: many questions, too few answers. Lancet Neurol. 2005a Mar;4(3):160-70.

Thwaites GE, van Toorn R, Schoeman J. Tuberculous meningitis: more questions, still too few answers. Lancet Neurol. 2013 Oct;12(10):999-1010.

Torok ME, Chau TT, Mai PP, Phong ND, Dung NT, Chuong LV, et al. Clinical and microbiological features of HIV-associated tuberculous meningitis in Vietnamese adults. PLoS One. 2008;3(3):e1772.

Torok ME, Yen NT, Chau TT, Mai NT, Phu NH, Mai PP, et al. Timing of initiation of antiretroviral therapy in human immunodeficiency virus (HIV)--associated tuberculous meningitis. Clin Infect Dis. 2011 Jun;52(11):1374-83. 
Tortoli E, Urbano P, Marcelli F, Simonetti TM, Cirillo DM. Is real-time PCR better than conventional PCR for Mycobacterium tuberculosis complex detection in clinical samples? J Clin Microbiol. 2012 Aug;50(8):2810-3.

Traub M, Colchester AC, Kingsley DP, Swash M. Tuberculosis of the central nervous system. Q J Med. 1984 Winter;53(209):81-100.

Udani PM, Dastur DK. Tuberculous encephalopathy with and without meningitis. Clinical features and pathological correlations. J Neurol Sci. 1970 Jun;10(6):541-61.

Valenstein PN. Evaluating diagnostic tests with imperfect standards. Am J Clin Pathol. 1990 Feb;93(2):252-8.

van Stralen KJ, Stel VS, Reitsma JB, Dekker FW, Zoccali C, Jager KJ. Diagnostic methods I: sensitivity, specificity, and other measures of accuracy. Kidney Int. 2009 Jun;75(12):1257-63.

Venkataswamy MM, Rafi W, Nagarathna S, Ravi V, Chandramuki A. Comparative evaluation of BACTEC 460TB system and Lowenstein-Jensen medium for the isolation of $\mathrm{M}$. tuberculosis from cerebrospinal fluid samples of tuberculous meningitis patients. Indian J Med Microbiol. 2007 Jul;25(3):236-40.

Vidal JE, de Oliveira AC, Hernandez AV. CD4+ T-cell count and cerebrospinal fluid findings in HIV-infected patients with tuberculous meningitis. Int $\mathrm{J}$ Tuberc Lung Dis. 2010 Nov;14(11):1496-7

Vidal JE, Hernandez AV, de Oliveira AC, Dauar RF, Barbosa SP, Jr., Focaccia R. Cerebral toxoplasmosis in HIV-positive patients in Brazil: clinical features and predictors of treatment response in the HAART era. AIDS Patient Care STDS. 2005 Oct;19(10):626-34.

Vidal, J.E. Reação em cadeia da polimerase (PCR) em amostras de sangue no diagnóstico da toxoplasmose cerebral em pacientes com AIDS [Tese de Doutorado]. Instituto de Infectologia Emílio Ribas. São Paulo; 2005. 
Walusimbi S, Bwanga F, De Costa A, Haile M, Joloba M, Hoffner S. Metaanalysis to compare the accuracy of GeneXpert, MODS and the WHO 2007 algorithm for diagnosis of smear-negative pulmonary tuberculosis. BMC Infect Dis. 2013 Oct 30;13(1):507.

World Health Organization. Global Tuberculosis Report 2013. WHO Library. Genebra, Suíça; 2013.

Yone EW, Kengne AP, Moifo B, Kuaban C. Prevalence and determinants of extrapulmonary involvement in patients with pulmonary tuberculosis in a SubSaharan African country: a cross-sectional study. Scand J Infect Dis. 2013 Feb;45(2):104-11. 